UNIVERSIDADE DE SÃO PAULO

INSTITUTO DE QUÍMICA

Programa de Pós-Graduação em Ciências (Bioquímica)

LAURA FARKUH

\title{
ESTUDO E DESENVOLVIMENTO DE LIPOSSOMAS COM POTENCIAL PARA APLICAÇÃO EM BASE COSMÉTICA
}

\author{
Versão corrigida da Dissertação conforme Resolução CoPGr 5890 \\ O original se encontra disponível na Secretaria de Pós-Graduação do IQ-USP
}

São Paulo

Data do Depósito na SPG:

$04 / 04 / 2016$ 


\section{ESTUDO E DESENVOLVIMENTO DE LIPOSSOMAS COM POTENCIAL PARA APLICAÇÃO EM BASE COSMÉTICA}

Dissertação apresentada ao
Instituto de Química da
Universidade de São Paulo
para obtenção do título de
Mestre em Ciências
(Bioquímica)

Orientadora: $\operatorname{Prof}^{\mathrm{a}} \operatorname{Dr}^{\mathrm{a}}$ Iolanda Midea Cuccovia

São Paulo

2016 
Ficha Catalográfica

Elaborada pela Divisão de Biblioteca e

Documentação do Conjunto das Químicas da USP.

Farkuh, Laura

F229e Estudo e desenvolvimento de lipossomas com potencial para aplicação em base cosmética / Laura Farkuh. -- São Paulo, 2015. $88 \mathrm{p}$.

Dissertação (mestrado) - Instituto de Química da Universidade de São Paulo. Departamento de Bioquímica.

Orientador: Cuccovia, Iolanda Midea

1. Biomimetico I. T. II. Cuccovia, Iolanda Midea, orientador.

$574.192 \quad$ CDD 
Aos meus grandes amigos Catarina e Filipe, que estiveram comigo todos os dias ao longo dessa jornada. Amo vocês. 


\section{AGRADECIMENTOS}

À Profa Iolanda, muito obrigada por tudo! Por ter me recebido em seu laboratório de braços abertos, com paciência e disposta a ensinar desde o primeiro dia em que cheguei. Io, você é uma pessoa maravilhosa e me sinto muito honrada em ser sua aluna! Com certeza você é a melhor orientadora que eu poderia ter escolhido.

Ao Prof. Hernan, obrigada pelos inúmeros conselhos, abraços, incentivo e até mesmo pelas palavras muitas vezes duras de serem escutadas, porém sinceras e cheias de cuidado. Quero que guarde com você minha eterna admiração pela pessoa que você é!

Aos meus pais Alinete e Rogério, muito obrigada por sempre sustentarem meus sonhos e fazerem o possível para que eu possa alcança-los. Obrigada por sempre me dizerem que não importam as escolhas que eu faça, vocês só querem que eu seja feliz... vocês me fazem muito feliz apenas por existirem na minha vida!

Aos meus irmãos Aline e Alberto, obrigada pelos ótimos momentos que passamos juntos, é muito bom saber que seremos amigos para a vida inteira. Obrigada também pelos irmãos que vocês me deram, meus cunhados Cleiton e Juliana, que só vieram para completar nossa família. E não posso esquecer das minhas lindas sobrinhas, Júlia e Isabela, princesas do meu coração.

Aos meus familiares agradeço pelo apoio, pela força, pelo cuidado! Em especial agradeço às minhas duas avós, Maria e Nely, por quem tenho enorme respeito e carinho.

Ao Renato, obrigada por ser meu melhor companheiro! Por estar comigo na minha louca rotina, por me incluir na sua vida e por participar da minha. Nunca vou esquecer o quão importante você foi (e ainda tem sido) nessa fase, o quanto me deu forças para continuar quando eu achei que não iria conseguir mais. Agradeço também aos seus pais, Lúcia e Thales, que sempre me recebem muito bem e que de alguma forma também contribuíram durante a escrita desse trabalho.

À Catarina e ao Filipe gostaria de dizer que vocês são duas das pessoas mais importantes em minha vida. Não consigo pensar em nada para escrever aqui além das coisas que costumo dizer a vocês para expressar o que eu sinto. Todos os dias eu agradeço por ter vocês como amigos. Vocês me dão força, inspiração e fazem meu coração transbordar de bons sentimentos. Vocês estarão sempre vivos em meu coração, assim como todos os momentos que partilhamos. Obrigada por sempre me aceitarem como sou. 
Aos meus amigos Clauden, Bia, Mari, Péricles, Matheus, Monique e Roger agradeço por sempre estarem presentes em minha vida de alguma forma, nunca me deixando esquecer dos laços que criamos.

Aos meus amigos que considero família, Juju, Thiago e Renatinha, obrigada pela convivência, pelas risadas e choros, por todos os momentos que dividimos ao longo destes últimos anos. Vocês são muito especiais!

À minha amiga Greice, muito obrigada, infinitamente obrigada. Nunca esquecerei que você me ensinou tudo quando cheguei ao laboratório e que até hoje me ensina um milhão de coisas. É muito bom sempre contar com você! Espero que você saiba que também pode contar comigo. Quero ser sua amiga por todos os anos que ainda virão.

À Marcela, agradeço por ter me dado suporte em diversos momentos ao longo do meu mestrado, pela amizade e carinho, pelos conselhos e pela sinceridade sempre.

Aos meus amigos Lu, Ray e João, agradeço por estarem comigo no dia-a-dia, pelas histórias divertidas que vocês me proporcionaram e até mesmo pelos momentos mais tensos e sérios em que dividimos as angústias. A amizade de vocês me dá ânimo e alegria ao longo dos dias!

A todos os meus colegas de laboratório quero agradecer pela convivência e por toda a compreensão e apoio com o meu trabalho. Obrigada por tornarem esse ambiente onde passamos a maior parte de nossos dias único e especial.

À Márcia, nossa técnica de laboratório, agradeço por toda a assistência durante a minha estadia no laboratório e também pelas inúmeras risadas, almoços e pela companhia dentro e fora do nosso ambiente de trabalho.

Ao Gustavo Battesini, obrigada por me aguentar por muitos desses dias (não foi fácil, eu sei), com todos os meus humores, me fazendo rir em todos os momentos. Obrigada pelo empenho em me ajudar durante os experimentos, na escrita deste trabalho e pelas inúmeras dicas que você me deu (desculpe, não pude usar as 5 páginas).

À Profa Flávia, agradeço pelos abraços, pelo carinho, pelos conselhos, cuidados...e por simplesmente estar na minha vida! Ter você por perto torna os meus dias muito melhores!

Ao Paulo, à Débora e à Fefa, agradeço pelo incentivo para a conclusão deste trabalho e pelo incentivo que me deram de diversas formas. Agradeço especialmente ao Paulo por ter contribuído ativamente na idealização e concretização do meu projeto de mestrado.

À Profa Salette Reis, obrigada por ter me recebido em seu laboratório na Universidade do Porto em Portugal e por ter contribuído com o meu trabalho. À Cláudia Nunes, que me 
orientou, ajudou e partilhou comigo um pouco do muito o que sabe. Agradeço também à Profa. Marcela Segundo e à Luísa Barreiros, que tanto se esforçaram com a quantificação do ácido láurico.

Gostaria de agradecer a alguns professores que me inspiraram durante a minha estadia no IQ e por quem tenho enorme admiração. São eles: Profa Clélia, Prof. Bayardo e Profa Bianca. Também agradeço a Profa Shirley Schreier pela participação que teve durante o meu trabalho e pela pessoa genial que é!

Ao Prof. Cristiano Luis Pinto de Oliveira, do Instituto de Física da USP, agradeço pelo auxílio para os experimentos de SAXS. Agradeço também ao Pedro Oseliero e a Bárbara Gerbelli, que muito contribuíram me enviando materiais, discutindo resultados comigo e se disponibilizando a me ajudar.

Ao Dr. Rodrigo Portugal e ao Dr. Alexandre Cassago do LNNano agradeço pelas análises de Crio-microscopia.

Ao CNPQ pela bolsa de mestrado concedida durante a realização do meu trabalho no IQ-USP. 


\section{RESUMO}

Farkuh, L. Estudo e Desenvolvimento de Lipossomas com Potencial para Aplicação em Base Cosmética. 2016. 88 p. Dissertação- Programa de Pós-Graduação em Ciências (Bioquímica). Instituto de Química, Universidade de São Paulo, São Paulo.

A acne vulgar é uma das doenças cutâneas mais comuns, apresentando como um de seus fatores fisiopatológicos primários a colonização pelo microrganismo Propionibacterium acnes. Atualmente, têm-se buscado terapias alternativas para o combate ao P. acnes, destacando-se alguns ácidos graxos, como o ácido laúrico (LA). O LA é uma molécula pouco solúvel em água, sendo possível sua incorporação em lipossomas. Os lipossomas apresentam capacidade de encapsulação/ liberação de ativos e impedem a desidratação da pele, tornandose ingredientes inovadores na área de cosméticos. Foram preparados lipossomas de dipalmitoilfosfatidilcolina (DPPC) contendo diferentes concentrações de LA, que variaram de 0 a $50 \%$ da concentração total em mol, em quatro pHs: 9,0, 7,4, 5,0 e 3,0. Nestes pHs o estado de protonação do LA muda variando de 0 a -1 . Os lipossomas foram extrusados por filtros com poros de $100 \mathrm{~nm}$ de diâmetro visando à obtenção de vesículas unilamelares grandes (LUV). As LUV foram caracterizadas quanto a sua estabilidade em condições de prateleira, temperatura de transição de fase da bicamada, encapsulamento no interior aquoso, liberação do LA, difusão das vesículas na pele e seus aspectos morfológicos foram caracterizados por espalhamento de raios-X a baixo ângulo (SAXS) e crio-microscopia eletrônica de transmissão. Estudos de estabilidade mostraram que independentemente da concentração de LA, as formulações são mais estáveis em pHs mais altos, quando LA está em sua maioria na forma de laurato. Os experimentos de DSC revelaram que em pHs 3,0 e 5,0 e concentrações maiores de LA, a interação deste ácido graxo com as bicamadas é favorecida, havendo um aumento da temperatura de transição de fase (Tm) e diminuição da cooperatividade. Análises de taxa de incorporação de sondas hidrofílicas confirmaram a presença de um compartimento aquoso interno para as vesículas de DPPC:LA. O LA conseguiu permear a pele no período avaliado e pouco LA foi liberado das vesículas em condições de temperatura ambiente. A morfologia das LUV se mostrou bem diferente da esperada e se observaram vesículas com mais de uma bicamada e outros formatos que não o esférico. Estes resultados podem auxiliar na otimização das condições para uma formulação que poderá ser usada no tratamento da acne, aumentando a eficácia do LA no sítio alvo.

Palavras-chave: Ácido Láurico, Vesículas Unilamelares Grandes, Acne. 


\begin{abstract}
Farkuh, L. Study and Development of Liposomes with Potencial Cosmetic Application. 2016. 88 p. Master Thesis- Graduate Program in Biochemistry. Instituto de Química, Universidade de São Paulo, São Paulo.

Acne vulgaris is one of the most common skin diseases, presenting as one of its causes the microorganism Propionibacterium acnes colonization. Currently, it has been sought alternatives therapies against $P$. acnes, especially some fatty acids, like the lauric acid (LA). LA is a molecule with low water solubility, allowing its incorporation in liposomes. Liposomes have encapsulation/release capacity of drugs and promote skin lipids regeneration, becoming an innovative ingredient in cosmetics area. Dipalmitoylphosphatidylcholine (DPPC) vesicles containing different LA concentrations were prepared at pHs: 9.0, 7.4, 5.0 and 3.0. At these $\mathrm{pHs}$ the LA protonation changes and its charge varies from 0 to -1 . The vesicles were extruded through filters containing pores of $100 \mathrm{~nm}$ to obtain large unilamellar vesicles (LUV) that were characterized for stability in shelf conditions, bilayer phase transition temperature, aqueous internal compartment encapsulation, LA release and in vitro skin permeation. Its morphological features were characterized by small angle X-ray scattering (SAXS) and cryo-electron transmission microscopy. Stability assays showed that, regardless LA concentration, formulations were more long-term stable in higher $\mathrm{pHs,}$ when LA is mostly in the form of laurate. The differential scanning calorimetry, DSC, experiments showed that, at pHs 3.0 and 5.0 and higher LA concentrations, the interaction between the bilayer and LA is favored, increasing phase transition temperature (Tm) and reducing cooperativity. Incorporation of hydrophilic probes confirmed the presence of an internal aqueous compartment in DPPC:LA vesicles. The LA managed to permeate the skin on the period evaluated and, in ambient conditions, low LA concentration was released from the vesicles. LUV containing more than one bilayer and non-spherical structures were observed. The obtained results may help in the optimization of the conditions for a formulation that can be used in the treatment of acne and improving the effectiveness of LA delivery to the target site.
\end{abstract}

Keywords: Lauric acid, Large Unilamellar Vesicles, Acne. 


\section{LISTA DE FIGURAS}

Figura 1- Eventos desencadeados pela acne vulgar............................................................ 14

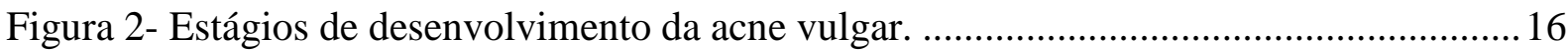

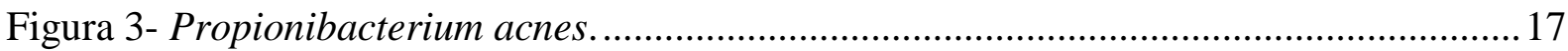

Figura 4- Imagem de microscopia de biofilme formado pelo microrganismo

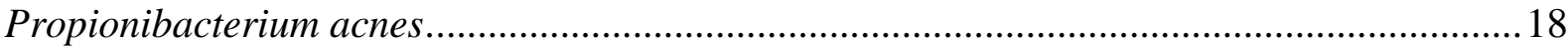

Figura 5- Peróxido de Benzoíla.......................................................................................... 20

Figura 6- Atividade do BPO comparado ao ácido láurico (Nakatsuji et al., 2009)................. 22

Figura 7- Representação de lipossoma e da bicamada lipídica. ..............................................23

Figura 8- Diferentes tipos de estruturação das vesículas...................................................... 24

Figura 9-Agregados formados por moléculas anfipáticas de diferentes geometrias................25

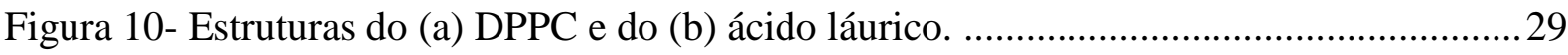

Figura 11- Esquema de preparo de vesículas pelo método de hidratação do filme lipídico. ... 30

Figura 12- Extrusão de MLV para se obter vesículas unilamelares grandes, LUV. ................ 30

Figura 13- Membrana na fase gel e depois na fase líquido-cristalina, acima da tem0peratura de

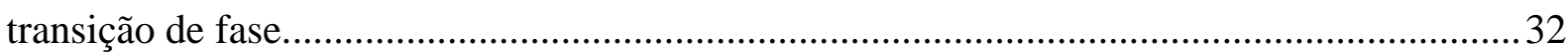

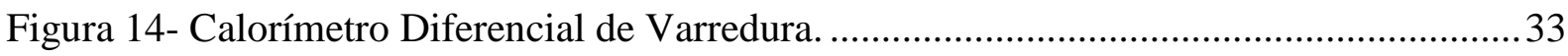

Figura 15- Equipamento Nanostar Bruker utilizado nas medidas de SAXS . ...........................35

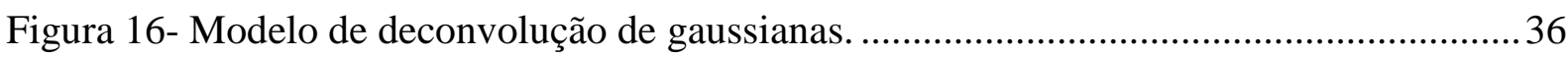

Figura 17- Perfil de densidade eletrônica da bicamada, indicando em vermelho a espessura da

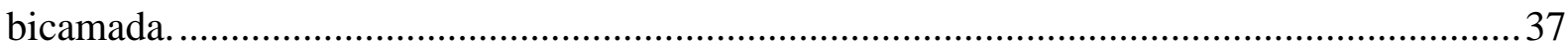

Figura 18- Exemplo de imagem 2-D para uma amostra vitrificada. ...................................... 38

Figura 19- Preparo das amostras para Crio-TEM pelo Dr. Alexandre Cassago no LNNano-

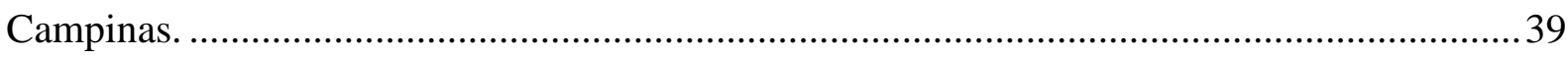

Figura 20- Estrutura da molécula de 5(6)-carboxifluoresceína............................................... 40

Figura 21- Estrutura da molécula do Pireno Tetrasulfonato de Sódio. ..................................... 41

Figura 22- Cromatografia de permeação em gel por exclusão de tamanho. ............................. 41

Figura 23- Cromatograma obtido para o encapsulamento de sonda fluorescente. O primeiro e menor pico corresponde às vesículas contendo fluoróforo em seu interior e o pico maior, ao fluoróforo não encapsulado. No inserto é mostrada a fluorescencia das amostras contendo as LUV com CF.

Figura 24- Esquema mostrando o príncipio da técnica de EPR com a transição entre os níveis

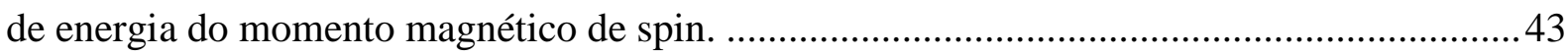

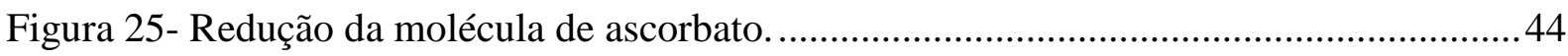

Figura 26- Reação entre o marcador de spin CAT1 e o ascorbato............................................ 44

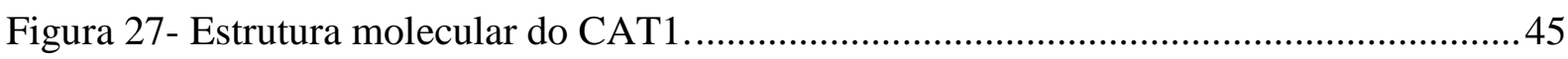

Figura 28- Esquema do experimento de liberação do LA. ......................................................... 46

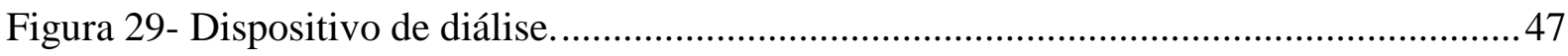

Figura 30- Sistema de difusão de Franz ............................................................................. 48

Figura 31- Variação nos valores de Dh e PdI em função do tempo para LUV diferentes concentrações de LA em tampão borato $10 \mathrm{mM}$, pH 9,0 ........................................................52 
Figura 32- Variação nos valores de Dh e PdI ao em função do tempo para LUV com diferentes concentrações de LA em tampão tris-HCl $10 \mathrm{mM} \mathrm{pH} \mathrm{7,4.}$

Figura 33- Valores de Dh e PdI para LUV com diferentes \%de LA em tampão acetato $10 \mathrm{mM}$,

$\mathrm{pH} 5,0$.

Figura 34- Efeito do tempo de incubação nos valores de Dh e PdI para LUV com diferentes concentrações de LA em tampão acetato $10 \mathrm{mM}$ pH 5,0.

Figura 35- Valores de Dh e PdI para LUV com diferentes \% de LA em tampão formiato 10 $\mathrm{mM}, \mathrm{pH} 3,0$.....

Figura 36- Efeito do tempo de incubação nos valores de Dh e PdI para LUV com diferentes concentrações de LA em tampão formiato $10 \mathrm{mM}$, pH 3,0.

Figura 37- Amostra de LUV com formação de precipitados em: a) Tampão acetato, $10 \mathrm{mM}$,

pH 5,0; b) Tampão formiato $10 \mathrm{mM}, \mathrm{pH} \mathrm{3,0} \mathrm{.}$

Figura 38- Termogramas das LUV de DPPC/LA nos tampões (a)borato 10mM pH 9,0, (b) tris- $\mathrm{HCl} 10 \mathrm{mM} \mathrm{pH} \mathrm{7,4,} \mathrm{(c)} \mathrm{acetato} 10 \mathrm{mM}$ pH 5,0 e (d) formiato $10 \mathrm{mM} \mathrm{pH} \mathrm{3,0.}$

Figura 39- Valores de Tm de LUV de DPPC:LA obtidos para cada concentração de LA em diferentes pHs.

Figura 40- Dados experimentais de SAXS (círculos abertos) e ajuste com o modelo (linha cheia). Os ajustes são bastante satisfatórios em toda a região de q considerada. As LUV de DPPC:LA foram preparadas em tampão Tris-HCl, 10 mM, pH 7,4. A concentração das LUV era $10 \mathrm{mM}$.

Figura 41- A curva experimental de SAXS mostrando vesículas A) multilamelares e B) unilamelares

Figura 42- Perfil de contraste de densidade eletrônico da bicamada lipídica de LUV em pH 7,4 contendo diferentes razões DPPC:LA obtido a partir do ajuste dos dados experimentais de SAXS.

Figura 43- Comportamento da espessura da bicamada em função da \% de LA nas LUV em vários pHs; barras de erros com desvio padrão estão representadas verticalmente.

Figura 44- Comportamento da periodicidade lamelar em função da \% de LA das LUV; barras de erros com desvio padrão estão representadas verticalmente.

Figura 45- Comportamento do Parâmetro de Caillè em função da \% LA de LUV de DPPC:LA da amostra; barras de erros com desvio padrão estão representadas verticalmente.

Figura 46- Comportamento do número médio de bicamadas correlatas, N, em função \%de LA das LUV; barras de erros com desvio padrão estão representadas verticalmente.

Figura 47- Imagens de Crio-EM de LUV de DPPC em pH 7,4 (acima) e pH 5,0 (abaixo)..... 70

Figura 48- Imagens de Crio-EM de LUV de DPPC:LA 70:30 em pH 7,4 (acima) e pH 5,0 (abaixo)

Figura 49- Imagens de Crio-EM de LUV de DPPC:LA 50:50 em pH 7,4 (acima) e pH 5,0 (abaixo)

Figura 50- Comparação da porcentagem de encapsulamento de $\mathrm{CF}$ com o obtido usando

CAT1 em LUV de DPPC:LA, ambos em tampão Tris-HCl 50 mM, pH 7,4. .77

Figura 51- Comparação da porcentagem de encapsulamento de PTS com o obtido usando CAT1 em LUV de DPPC:LA, ambos em tampão acetato $50 \mathrm{mM}, \mathrm{pH} 5,0$. 
Figura 52- Concentração de LA liberado com o tempo das LUV de (a) DPPC:LA 90:10; (b) DPPC:LA 70:30 e (c) DPPC:LA 50:50 nos tampões acetato, 0.01 M pH 5,0 e tampão Tris$\mathrm{HCl} 0.01 \mathrm{M} 7,4$. A concentração de LUV é $0.5 \mathrm{mM}$.

Figura 53- Porcentagem de permeação de LA com o tempo de LUV de DPPC:LA em tampão Tris- $\mathrm{HCl} 10 \mathrm{mM}, \mathrm{pH} 7,4$. [LUV] $=0.5 \mathrm{mM}$.

Figura 54- Porcentagem de permeação de LA com o tempo de LUV de DPPC:LA em tampão acetato $10 \mathrm{mM}, \mathrm{pH} 5,0 .[\mathrm{LUV}]=0.5 \mathrm{mM}$. 


\section{SUMÁRIO}

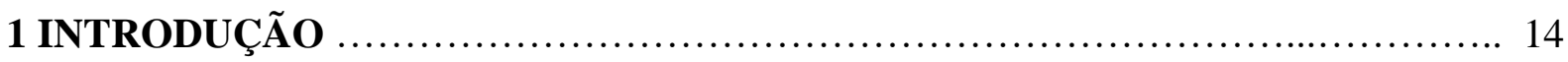

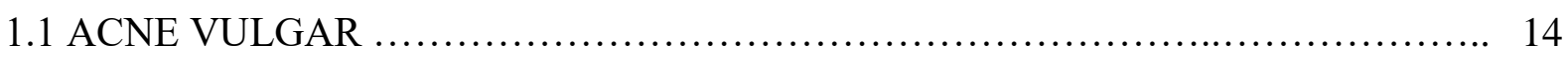

1.1.2 Propionibacterium acnes ............................................ 17

1.1.3 Terapias no tratamento da acne vulgar .................................. 19

1.1.3.1 Retinóides ................................................................ 19

1.1.3.2 Peróxido de Benzoíla (BPO) ............................................. 19

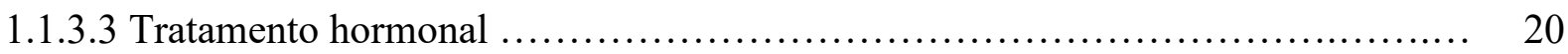

1.1.3.4 Antibióticos ....................................................... 20

1.1.3.5 Outras estratégias no tratamento da acne ................................. 21

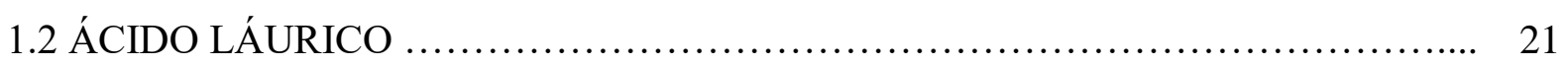

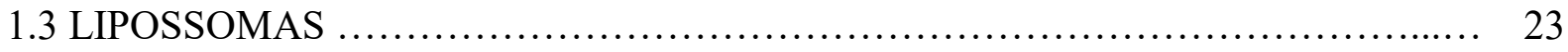

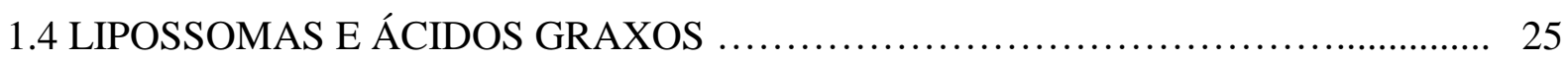

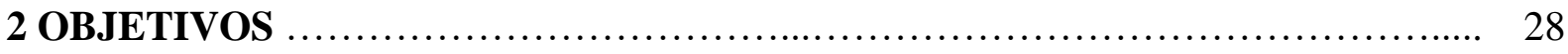

3 MATERIAIS E MÉTODOS ............................................... 29

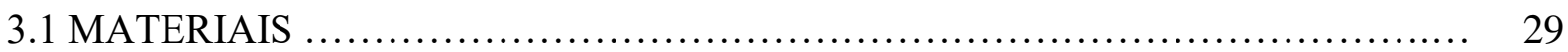

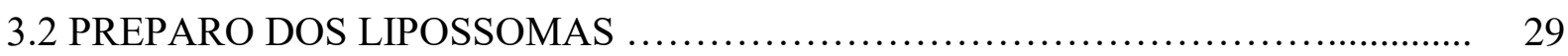

3.3 ESTABILIDADE DAS VESÍCULAS COM ÁCIDO LÁURICO ................... 30

3.3.1 Medidas do Diâmetro Hidrodinâmico e do Índice de Polidispersidade .............. 32

3.4 CALORIMETRIA DIFERENCIAL DE VARREDURA .......................................... 32

3.4.1 Determinação da Tm e Cooperatividade por DSC ............................................. 34

3.5 ESPALHAMENTO DE RAIOS-X A BAIXO ÂNGULO (SAXS) …........................ 34

3.5.1 Medidas de SAXS e Ajuste dos Dados Experimentais ....................................... 35

3.5.1.1 Ajuste das Curvas de Espalhamento................................................................. 35

3.5.1.2 Fator de Estrutura ..................................................................................... 36

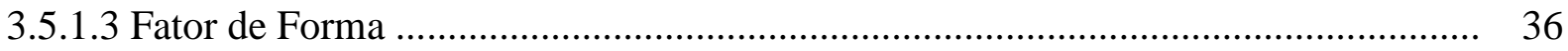

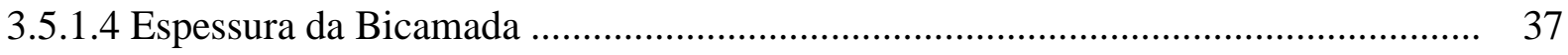

3.6 CRIO-MICROSCOPIA ELETRÔNICA DE TRANSMISSÃO ................................. 37

3.6.1 Preparo das Amostras para Crio-TEM e Aquisição das Imagens ..................... 38

3.7 ENCAPSULAMENTO DE SONDAS NO COMPARTIMENTO AQUOSO

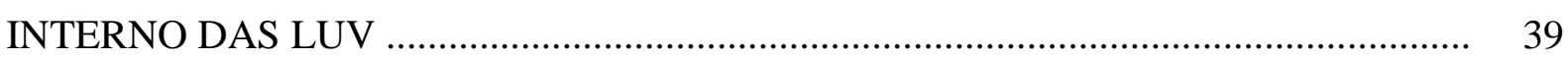

3.7.1 Encapsulamento de Sondas Fluorescentes …................................................. 39 
3.7.1.1 Vesículas com CF/PTS e Medidas de Fluorescência ............................................. 41

3.7.2 Encapsulamento de Marcador de Spin ............................................................ 43

3.7.2.1 Vesículas com CAT1 e Medidas de EPR ............................................................. 44

3.8 LIBERAÇÃO DO ÁCIDO LÁURICO MEDIDA POR DIÁLISE ............................. 46

3.9 DIFUSÃO DO ÁCIDO LÁURICO POR CÉLULA DE FRANZ .............................. 47

3.10 QUANTIFICAÇÃO DOS FOSFOLIPÍDIOS ........................................................ 48

3.11 QUANTIFICAÇÃO DO ÁCIDO LÁURICO ........................................................ 49

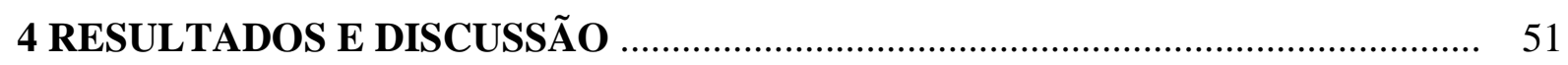

4.1 ESTABILIDADE DAS VESÍCULAS COM ÁCIDO LÁURICO .............................. 51

4.2 CALORIMETRIA DIFERENCIAL DE VARREDURA ....................................... 57

4.3 ESPALHAMENTO DE RAIOS-X A BAIXO ÂNGULO (SAXS) ............................. 61

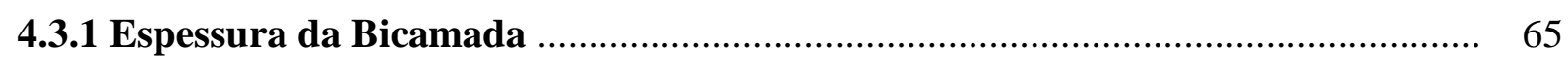

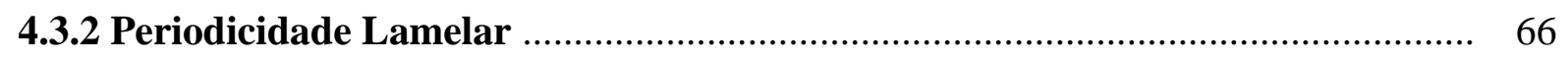

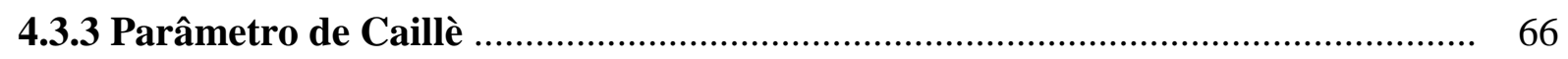

4.3.4 Número Médio de Camadas Correlatas .............................................................. 68

4.4 CRIO-MICROSCOPIA ELETRÔNICA DE TRANSMISSÃO _.................................. 69

4.5 ENCAPSULAMENTO DE SONDAS NO COMPARTIMENTO AQUOSO

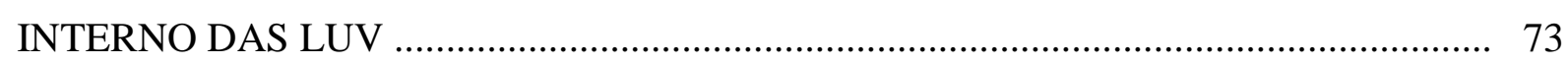

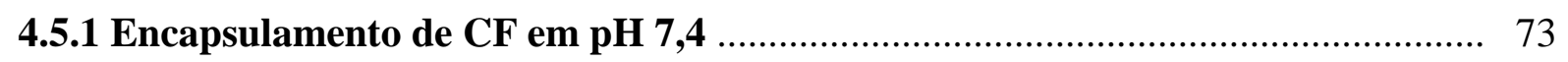

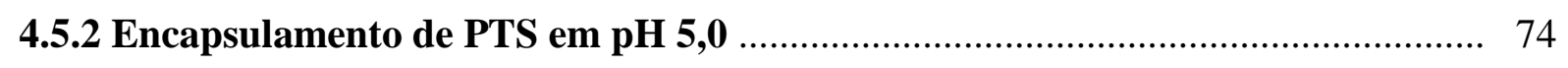

4.5.3 Encapsulamento de CAT1 nas LUV ............................................................... 75

4.6 LIBERAÇÃO DO ÁCIDO LÁURICO MEDIDA POR DIÁLISE ……......................... 78

4.7 DIFUSÃO DO ÁCIDO LÁURICO POR CÉLULA DE FRANZ ................................. 80

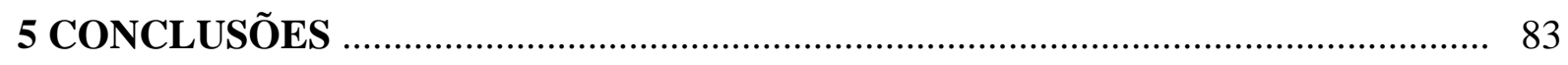

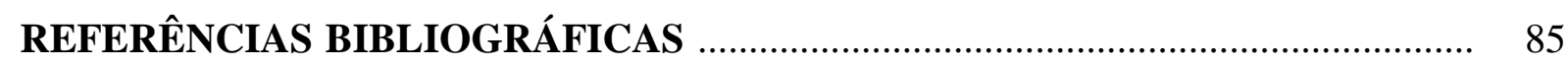




\section{INTRODUÇÃO}

\subsection{ACNE VULGAR}

A acne vulgar é uma das doenças de pele mais comuns que afeta cerca de $85 \%$ da população em algum momento de sua vida. A acne é uma doença do folículo pilossebáceo, que possui como características a hiperprodução sebácea, a hiperqueratinização folicular, o aumento da colonização pelo microrganismo Propionibacterium acnes e a inflamação dérmica (FIGURA 1). A sequência exata dos eventos e como eles interagem ainda são desconhecidos.

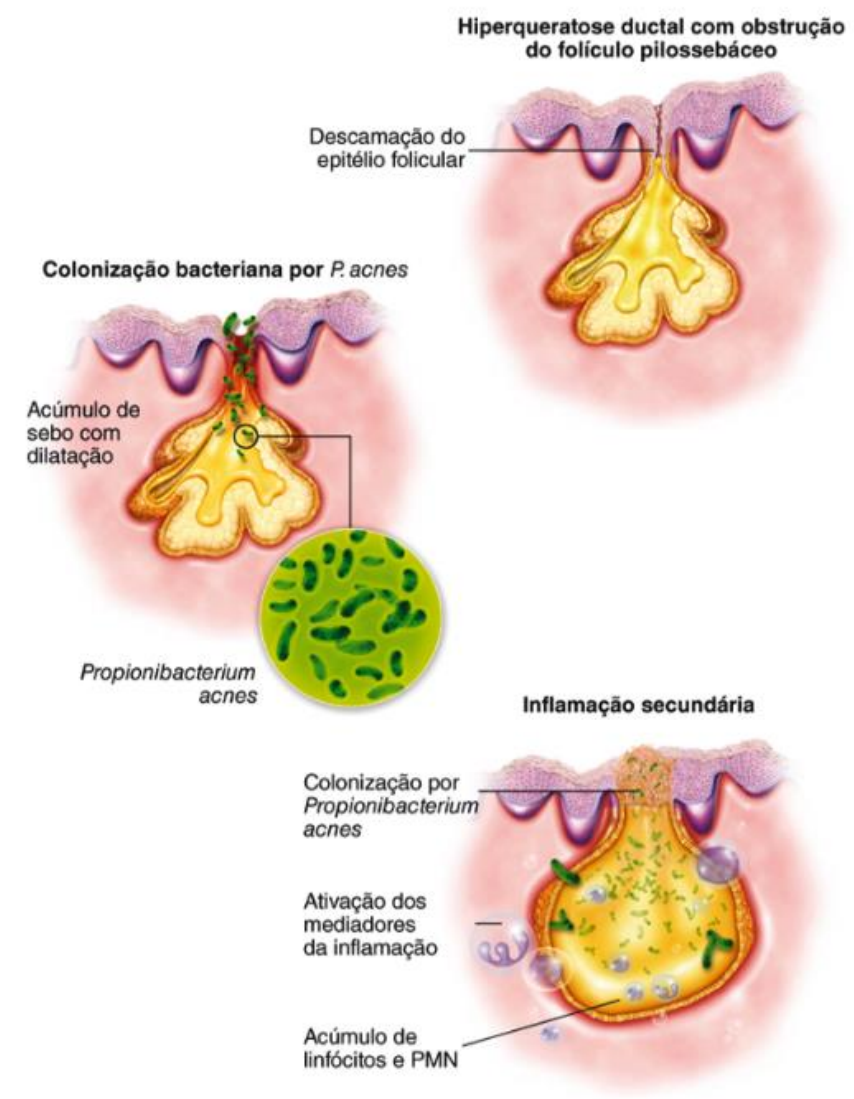

Figura 1- Eventos desencadeados pela acne vulgar.

As características clínicas da acne incluem excesso de oleosidade da pele, lesões não inflamatórias (comedões abertos e fechados) e lesões inflamatórias (pápulas e pústulas) que podem deixar cicatrizes na pele. Geralmente a acne ocorre nos locais do corpo com maior concentração de unidades pilosebáceas como a face, o pescoço e a parte superior do tronco. 
As unidades pilosebáceas são caracterizadas como canais foliculares dilatados, preenchidos com queratina, lipídios e microrganismos (STRAUSS; KLIGMAN, 1960).

Apesar de se manifestar com menor intensidade em orientais e em pessoas de pele negra, a acne ocorre em todas as raças, sendo que os casos mais graves tendem a se manifestar em indivíduos do sexo masculino (afetando 95\% de indivíduos do sexo masculino contra $83 \%$ do sexo feminino) devido à influência dos hormônios andrógenos. Após os 20 anos de idade a doença tende a regredir espontaneamente mas, em alguns casos, pode persistir também na fase adulta (GOLDBLUM, 2003).

A influência genética na acne é muito importante, acreditando-se que ela seja proporcional ao grau de dermatose; essa influência ocorre sobre o controle hormonal, hiperqueratinização folicular e secreção sebácea, mas não na infecção bacteriana.

A hiperqueratinização folicular é o primeiro fator para o desenvolvimento da acne vulgar. Com ela se forma um "tampão" córneo que retém o conteúdo sebáceo no interior da glândula. No interior dessa lesão, as proteases produzidas pelo $P$. acnes agem sobre o epitélio glandular rompendo-o, o que facilita a expulsão do conteúdo sebáceo para a derme (BOJAR; HOLLAND, 2004).

Referindo-se aos fatores etiopatogênicos da acne, há alteração nos componentes do sebo dos portadores da doença em comparação com os indivíduos sãos. Em ambos os grupos, a proporção de ácidos graxos livres (11\%-18\%), esqualeno (10\%-12\%), colesterol e seus ésteres (juntos, menor que 5\%) é similar. No entanto, a proporção de triglicérides no primeiro é de 46\%-52\%, contra 60\%-68\% no segundo, e a de ésteres de ácidos graxos é maior entre os acnéicos (20\%-26\%) em relação aos não acnéicos (9\%-12\%) (MCGINLEY et al., 1980).

Ultimamente, discute-se a participação dos ácidos graxos livres, obtidos pela hidrólise de triglicérides através das lipases do P. acnes, na etipatogênese da acne vulgar. Acredita-se que estes ácidos graxos acumulam-se no infundíbulo glandular por um longo período de tempo e que teriam a capacidade de irritar o epitélio acarretando, assim, a hiperqueratinização (estágio inicial da comedogênese) e, por fim, a inflamação (BOJAR; HOLLAND, 2004).

De todos os componentes do sebo alterados em portadores da acne, o ácido linoleico é um dos principais. O ácido linoleico, que está reduzido nos comedões, é um ácido graxo essencial, com importante papel na manutenção da função de barreira epidérmica. A alteração na barreira epidérmica facilita a penetração na derme de microrganismos e ácidos graxos próinflamatórios presentes no sebo, promovendo infecção e inflamação. Weeks et al. mostrou que os inibidores de lipase levaram a uma redução da quantidade de ácidos graxos na pele, 
mas não foram capazes de tratar completamente a acne. Frações lipídicas no sebo, geradas por outro mecanismo além do bacteriano, também parecem ser responsáveis pelo desenvolvimento da inflamação na acne (JAPPE, 2003).

Os andrógenos, por si, estimulam as glândulas sebáceas a produzirem sebo através de suas ações sobre receptores celulares (WEBSTER, 1995).

Historicamente, discute-se a possível relação entre a ingestão oral de algumas substâncias e a acne vulgar, mas os estudos ainda não conseguiram estabelecê-la. As críticas que se fazem a tais estudos com seres humanos são, muitas vezes, em função de limitações metodológicas não só na avaliação subjetiva, mas, também, na interpretação e confirmação dos resultados obtidos.

A acne pode ser classificada clinicamente em quatro níveis (FIGURA 2), de acordo com o seu grau de desenvolvimento:

Grau I: forma mais leve, não inflamatória, caracterizada pela presença de comedões abertos e fechados;

Grau II: acne inflamatória, presença de pápulas e pústulas, de conteúdo purulento;

Grau III: acne nódulo cística, com nódulos mais salientes;

Grau IV: acne conglobata, com a formação de abcessos.
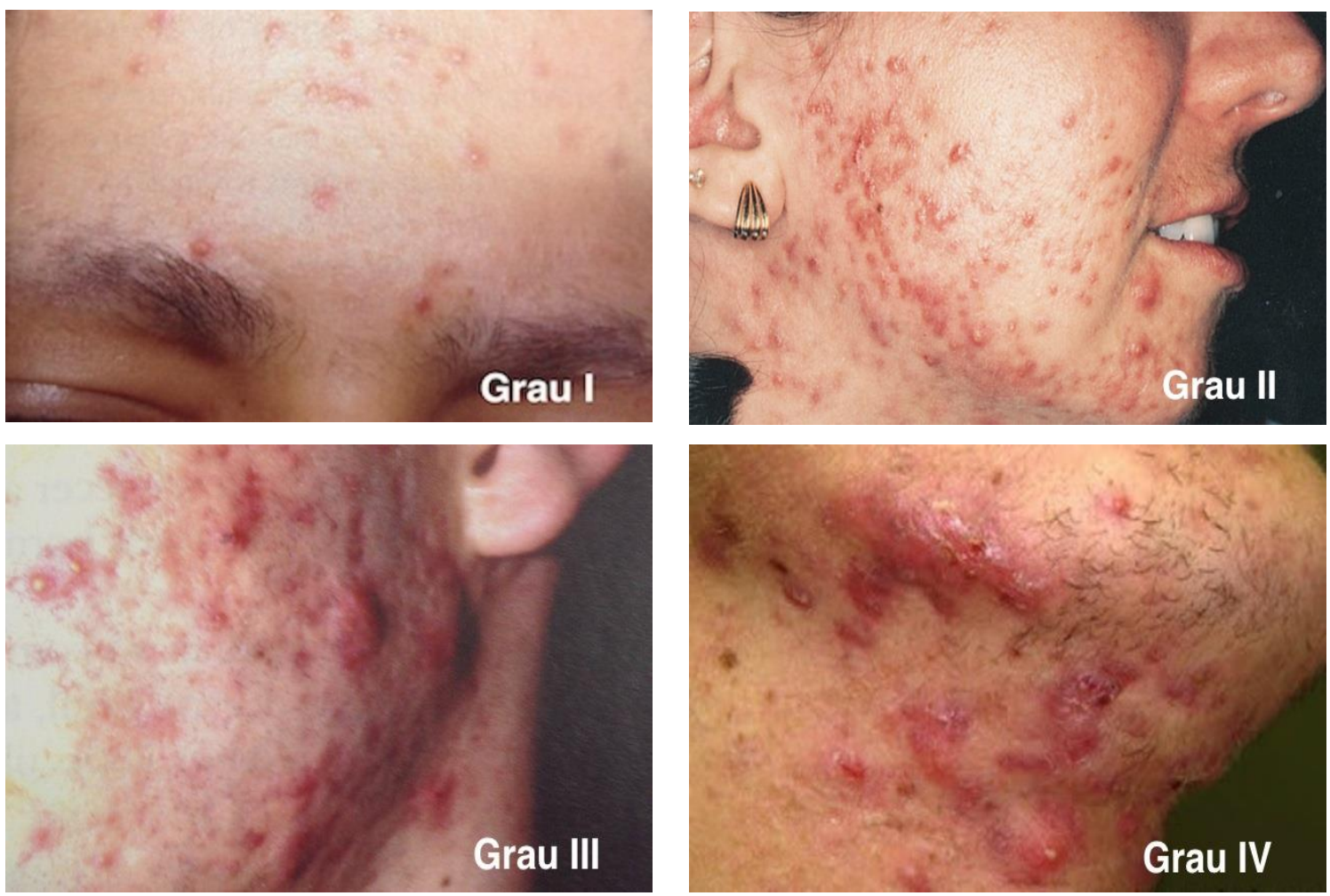

Figura 2- Estágios de desenvolvimento da acne vulgar. 
As complicações mais relevantes da acne vulgar são cicatrizes físicas e sequelas psicossociais, que podem persistir após o desaparecimento das lesões ativas. Os sintomas da acne afetam principalmente a qualidade de vida, sendo a segunda maior causa de suicídio entre as doenças de pele. A acne afeta a aparência da pele, um importante órgão relacionado à autoestima das pessoas e suas relações sociais (GOLDBLUM, 2003).

\subsubsection{Propionibacterium acnes}

O folículo pilosebáceo é um ambiente anaeróbico e rico em lipídios, propício ao desenvolvimento de microrganismos ( $P$. acnes, $P$. avidum, $P$. granulosum, $P$. propionicum, and P. lymphophilum) comensais na pele. Estas bactérias são gram positivas e anaeróbias, geralmente com condição ideal de desenvolvimento a 35² C (STRAUSS; KLIGMAN, 1960).

A pele normal é capaz de tolerar um número limitado de microrganismos. Geralmente as espécies gram positivas conseguem se estabelecer melhor nas condições desta região $(\mathrm{pH}$, disponibilidade de oxigênio e água, radiação ultravioleta, concentração de íons, etc), devido a sua parede celular que lhe confere alta estabilidade estrutural.

As populações de propionibacteria que se estabelecem na pele geralmente têm um efeito positivo sobre ela, criando um ambiente protegido contra a colonização de outros microrganismos patogênicos. Entretanto, quando o hospedeiro é submetido a algumas condições como trauma, baixa imunidade, entre outras, a propionibacteria pode desenvolver patogenicidade (MCDOWELL et al., 2005). A maioria dos trabalhos publicados sobre a microflora da pele diz respeito ao microrganismo P. acnes (FIGURA 3), um dos maiores desafios a ser superado para o tratamento da acne vulgar (NEWTON et al., 1997).

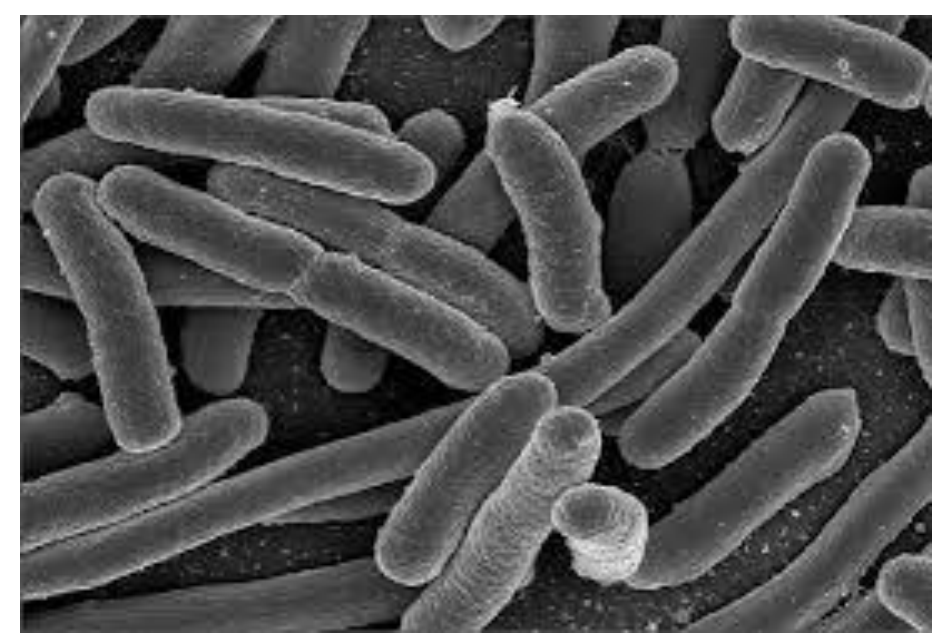

Figura 3- Propionibacterium acnes. 
A população de $P$. acnes costuma ser maior na face e no tronco superior do corpo, locais com maior concentração lipídica, indicando uma relação direta entre população bacteriana e seborréia local. Pressupõe-se que o aumento da população de $P$. acnes na superfície cutânea esteja relacionado com o aumento da produção de triglicérides e, talvez, de colesterol. Alterações na composição lipídica podem determinar a sobrevida da P. acnes.

Apesar dos demais fatores que contribuem para o desenvolvimento da acne, a hipótese de que o papel do microrganismo $P$. acnes é fundamental é sustentada pelo sucesso obtido em terapias que fazem uso de antibióticos e pela redução de sua eficácia demonstrada em tratamentos contra cepas de $P$. acnes resistentes a estes mesmos antibióticos. Ainda que diversos antibióticos possuam ação contra o $P$. acnes in vitro, seu uso no combate a acne é geralmente limitado devido à sua solubilidade, que desfavorece sua permeação na pele (BOJAR; HOLLAND, 2004).

Leyden et al. (1983) mostraram que a resistência da $P$. acnes é frequentemente desenvolvida em pacientes que fazem uso a longo prazo de antibióticos por via sistêmica. Porém, nas últimas décadas, tem sido discutida também uma possível relação entre o aumento de cepas resistentes de P. acnes e o uso de antibióticos tópicos (LEYDEN et al., 1983). Além do fator de resistência, ensaios in vitro mostraram que o $P$. acnes pode formar um biofilme no folículo (FIGURA 4), levando a uma diminuição da resposta aos agentes antimicrobianos.

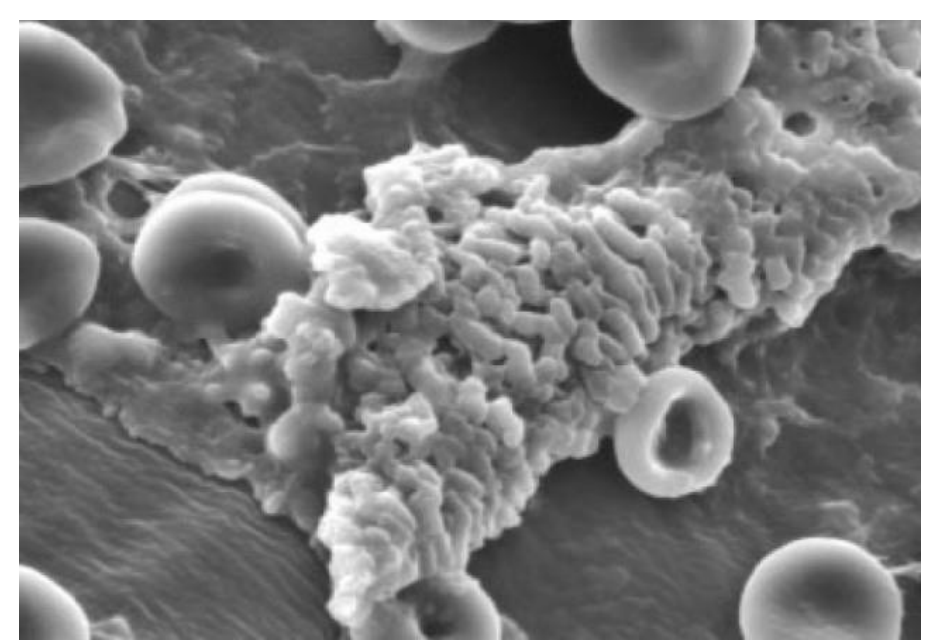

Figura 4- Imagem de microscopia de biofilme formado pelo microrganismo Propionibacterium acnes.

O importante papel do $P$. acnes na inflamação da acne se dá por sua fagocitose por leucócitos polimorfonucleares no lúmen glandular, acarretando liberação de enzimas hidrolíticas intracelulares e mantendo sua integridade. Além disso, os anticorpos específicos contra a $P$. acnes, presentes nos microcomedões, interagem com essas bactérias, liberando as 
proteases hidrolíticas na parede epitelial infundibular fragilizando-a e levando à saída de substâncias irritantes para a derme subjacente, desencadeando o processo inflamatório local (WEBSTER, 1995).

\subsubsection{Terapias no tratamento da acne vulgar}

As terapias atuais utilizadas para o tratamento da acne consistem em ativos que previnem a formação dos comedões e tenham ação anti-inflamatória e antimicrobiana. $\mathrm{Na}$ maioria das vezes esses ativos são retinóides de uso tópico (tetinoína, adapaleno, entre outros) e isotretinoína por via oral.

\subsubsection{Retinóides}

Os retinóides possuem ação queratolítica e anti-inflamatória, além de impedirem a proliferação e diferenciação celular.

A isotretinoína, administrada via oral, induz a glândula sebácea a reduzir seu tamanho através da diminuição da proliferação dos sebócitos, suprimindo assim a produção do sebo. Recentemente, têm sido relatados casos de depressão em pacientes tratados com isotretinoína, mas até o momento não foi estabelecida claramente a relação entre a terapia e a depressão. A isotretinoína é recomendada na maioria das vezes para casos de acne severa, com nódulos e que não respondem ao tratamento tópico (GOLLNICK; SCHRAMM, 1998).

O adapaleno, retinóide administrado via tópica, é vantajoso comparado aos demais retinóides, pois é altamente lipofílico e causa pouca irritação à pele. Apesar destas vantagens, o adapaleno não possui atividade contra o microrganismo P. acnes (JAPPE, 2003).

Os retinóides são contraindicados durante a gravidez e os efeitos adversos incluem ressecamento da pele, irritação, coceira e formigamento, principalmente nas fases iniciais do tratamento.

\subsubsection{Peróxido de Benzoíla (BPO)}

O Peróxido de Benzoíla (FIGURA 5) é efetivo na redução de colônias de $P$. acnes, inibindo o seu crescimento e sem risco de resistência relatada até o momento. São 
recomendadas concentrações de BPO de até $5 \%$, por ser menos irritante à pele (EADY et al., 1996).<smiles>O=C(OOC(=O)c1ccccc1)c1ccccc1</smiles>

Figura 5- Peróxido de Benzoíla.

A atividade do BPO no tratamento da acne e os baixos riscos que ele apresenta para a pele o tornam um dos ativos principais para pacientes com acne de grau leve a moderado (WEISS, 1997).

Estudos mostraram que a atividade do BPO pode ser ainda melhor quando combinado a outras terapias como retinóides de uso tópico e antibióticos.

\subsubsection{Tratamento hormonal}

Os tratamentos hormonais consistem na supressão da produção de andrógenos pelo ovário, através de contraceptivos de uso oral, bloqueadores dos receptores androgênicos.

Este tipo de terapia não é sempre a primeira opção, sendo indicado na maioria das vezes apenas para mulheres com acne leve ou sinais de produção em excesso de hormônios androgênicos e que pedem por contraceptivo (KATSAMBAS; PAPAKONSTANTINOU, 2004).

\subsubsection{Antibióticos}

Os antibióticos são capazes de reduzir a colonização bacteriana pela $P$. acnes no folículo piloso, porém apenas ativos lipofílicos são eficazes, tais como: clindamicina, tetraciclina, minociclina, eritromicina e gentamicina. Estes antibióticos em especial também possuem propriedades anti-inflamatórias, principalmente a minociclina (TOYODA; MOROHASHI, 1998). 
Os antibióticos de uso tópico atuam diminuindo a quantidade de ácidos graxos livres que contribuem para a inflamação, regulando o metabolismo da $P$. acnes e a produção extracelular de lipases. Entretanto, não é recomendado o uso desses antibióticos tópicos devido ao risco do microrganismo desenvolver resistência (KATSAMBAS; PAPAKONSTANTINOU, 2004).

Geralmente, os antibióticos são utilizados por via oral e combinados com outras terapias de uso tópico, como aquelas contendo BPO, que também possuem atividade antimicrobiana.

\subsubsection{Outras estratégias no tratamento da acne}

A maioria dos retinóides não tem efeito direto contra o $P$. acnes e, desta forma, não possuem eficiência no combate a todos os eventos relacionados à acne vulgar.

Alternativa bastante utilizada em produtos para a acne é o ácido salicílico, um componente esfoliante adicionado a produtos de uso tópico, que auxilia na atividade de outros ativos que podem ser usados em conjunto.

O desenvolvimento de novos ativos e terapias têm sido bastante abordados, de forma a superar as dificuldades encontradas para o tratamento da acne, que obteve pouco progresso nos últimos 50 anos (ELMAN; LEBZELTER, 2004).

\section{2 ÁCIDO LÁURICO}

Os ácidos graxos livres (FFAs, do inglês Free Fatty Acids) desempenham diferentes papéis na defesa do organismo, impedindo a entrada de patógenos ou microrganismos oportunistas. Eles criam um ambiente de $\mathrm{pH}$ ácido, com condições desfavoráveis para o desenvolvimento de determinadas bactérias e podem impedir seu crescimento ou levá-las à morte. Além disso, os ácidos graxos, saturados ou insaturados, impedem a adesão bacteriana e subsequente formação de biofilme. A ação dos ácidos graxos é tipicamente comparável à de peptídeos antimicrobianos naturais in vitro (NAKATSUJI et al., 2009).

Os ácidos graxos são os agentes antimicrobianos mais efetivos presentes na pele humana. Eles são produzidos por clivagem de lipídios secretados das glândulas sebáceas e a sua presença na pele é suficiente para controlar a microbiota bacteriana.

A atividade antibacteriana de cada ácido graxo é influenciada pelo comprimento da cadeia alquílica e estrutura. $\mathrm{O}$ grupo $\mathrm{OH}$ da carboxila parece ser importante para a atividade 
antibacteriana uma vez que ácidos graxos metilados geralmente apresentam pouca ou nenhuma atividade antibacteriana. Para ácidos graxos saturados, os mais ativos possuem entre 10 e 12 carbonos em sua cadeia (FISCHER et al., 2012).

O amplo espectro de atividades e modo de ação não específico de pelo menos alguns ácidos graxos os tornam atrativos agentes antibacterianos para várias aplicações na medicina, agricultura, preservação de alimentos e formulações cosméticas, especialmente aquelas em que a presença de antibióticos é indesejável ou proibida (DESBOIS; SMITH, 2010).

Vários FFAs possuem atividade contra bactérias Gram-positivas, mas não Gramnegativas. O ácido láurico (LA), presente em pequena quantidade no sebo, é o ácido graxo saturado com maior potencial antimicrobiano. Ele é comumente encontrado em produtos naturais como óleo de coco e leite. Além de o LA apresentar boa atividade contra diversas bactérias Gram-positivas ele possui ação in vivo contra o microrganismo P. acnes, podendo ser utilizado como agente antibacteriano natural no tratamento da acne (YANG et al., 2009).

Nakatsuji et al. demonstrou que a concentração inibitória mínima (MIC) do LA, a menor concentração para inibir o crescimento bacteriano, é até 15 vezes menor do que a do BPO (FIGURA 6).

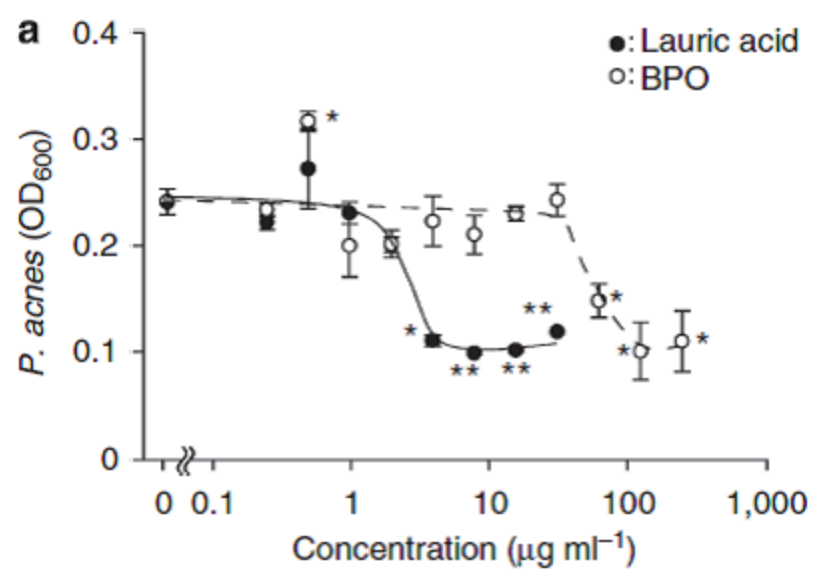

Figura 6- Atividade do BPO comparado ao ácido láurico (Nakatsuji et al., 2009).

Os resultados de Nakatsuji et al. mostraram que o LA possui atividade superior a do BPO, um agente antioxidante utilizado frequentemente no tratamento da acne contra as bactérias da pele $P$. acnes, $S$. aureus, e $S$. epidermidis. Além disso, os resultados mostraram que o $P$. acnes é a bactéria mais sensível ao LA entre outros microrganismos testados.

Em uma avaliação da atividade antimicrobiana dos ácidos láurico, oleico e palmítico contra a $P$. acnes in vitro o ácido graxo com maior ação bactericida foi o LA. 
O mecanismo de ação do ácido láurico contra o $P$. acnes envolve a separação das monocamadas de sua membrana, matando assim o microrganismo. Os FFAs antimicrobianos tendem a um menor desenvolvimento de resistência comparado a outros tratamentos com os antibióticos frequentemente utilizados (NAKATSUJI et al., 2009).

O grande desafio no uso do LA em uma formulação para o tratamento da acne está relacionado à sua solubilidade. O LA é pouco solúvel em água e solventes como dimetil sufóxido (DMSO), que podem ser tóxicos a pele, são necessários para solubilizá-lo.

Os lipossomas têm sido amplamente estudados como carreadores de fármacos, apresentando grande potencial para veiculação de drogas (“drug delivery”) de aplicação tópica, levando o princípio ativo ao sítio de interesse em maiores concentrações do que as formulações convencionais.

Os resultados de Yang et al. mostraram que o uso de lipossomas favoreceu a ação do LA, que foi eficaz até em baixas concentrações. O LipoLA ( nome dado por Yang para lipossoma com ácido láurico) foi capaz de se fundir com a membrana do $P$. acnes e liberar o LA na membrana da bactéria (YANG et al., 2009).

\subsection{LIPOSSOMAS}

Os lipossomas são vesículas formadas por fosfolipídios, constituídas de uma ou mais bicamadas orientadas em torno de um compartimento interno aquoso (FIGURA 7). Usaremos aqui as palavras lipossoma e vesícula como sendo equivalentes. Os lipossomas, ou vesículas, podem ser classificados de acordo com o seu tamanho, número de lamelas (bicamadas), constituição lipídica e método de preparo.

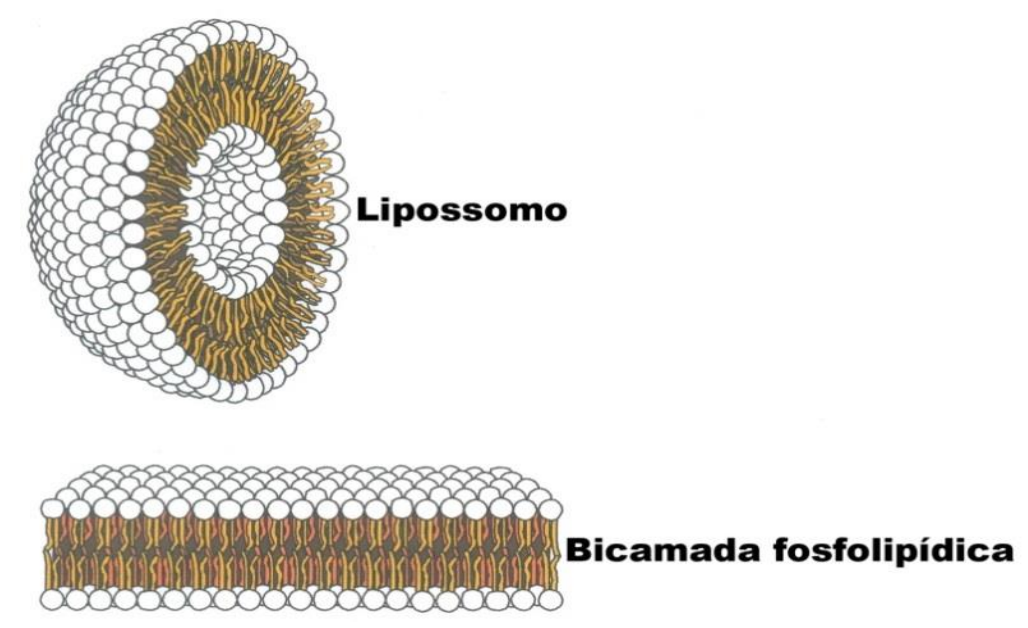

Figura 7- Representação de lipossoma e da bicamada lipídica. 
As vesículas podem ser preparadas por extrusão, sonicação, agitação, liofilização, congelamento e descongelamento, evaporação em fase reversa, entre outros. O diâmetro das vesículas é determinado pelo método de preparação e pode variar de 20 a $5000 \mathrm{~nm}$.

A nomenclatura dos lipossomas é baseada em seu número de lamelas e tamanho (FIGURA 8), podendo ser divididas nas seguintes categorias:

a) Vesículas unilamelares pequenas (Small Unilamellar Vesicles - SUV): formadas por uma única bicamada, são as menores, com diâmetro variando de 20 a 80 nm;

b) Vesículas unilamelares grandes (Large Unilamellar Vesicles - LUV): formadas por uma única bicamada lipídica, com tamanho intermediário e diâmetro entre 80 e $1 \mu \mathrm{m}$

c) Vesículas multilamelares (Multilamellar Vesicles - MLV): formadas por várias bicamadas lipídicas, com tamanho médio e diâmetro que varia de $400 \mathrm{~nm}$ a alguns micrometros;

d) Vesículas gigantes (Giants Unillamelars Vesicles - GUV): normalmente formadas por uma única bicamada lipídica, apresentam diâmetro superior a $1 \mu \mathrm{m}$.

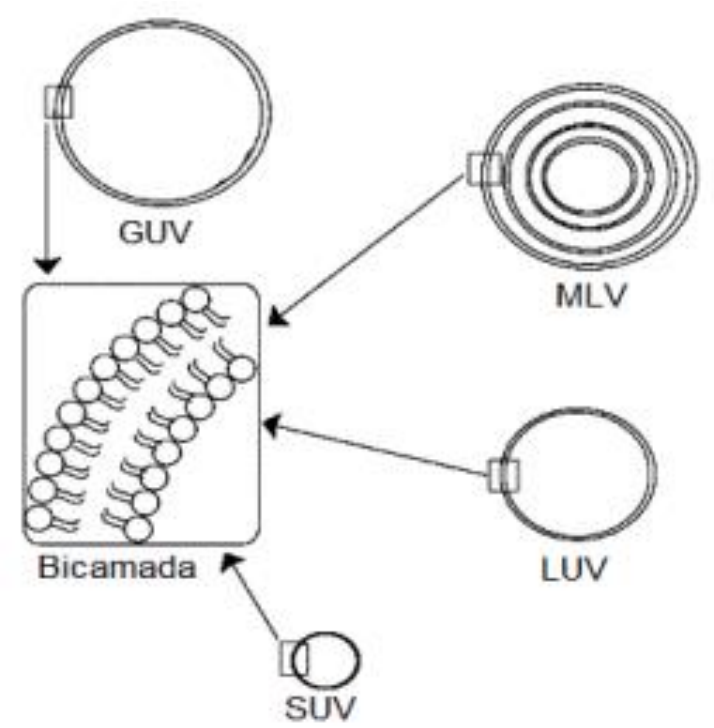

Figura 8- Diferentes tipos de estruturação das vesículas.

A princípio os lipossomas eram utilizados como modelos biomiméticos de membranas biológicas. A partir da década de 70, outras aplicações práticas dos lipossomas obtiveram destaque, como seu uso em drug delivery (LASIC, 1998).

Os lipossomas apresentam diversas propriedades que os tornam atraentes para seu uso e aplicação, tais como: 
- Biocompatibilidade;

- São capazes de encapsular ativos em seu interior aquoso, quando hidrofílicos, ou na membrana, caso este ativo seja hidrofóbico;

- O ativo de interesse se torna protegido das condições externas do organismo, evitando também reações adversas indesejáveis;

- O tamanho, a carga e as propriedades dos lipossomas podem ser controlados facilmente, selecionando-se os lipídios e método de preparo adequado.

Estratégias têm sido traçadas para prolongar o tempo de permanência dos lipossomas no organismo, garantindo sua estabilidade e eficácia (BLUME; CEVC, 1990).

Entre as vias de administração de lipossomas, que tem se mostrado cada vez mais promissora com o passar dos anos, está a sua aplicação tópica (TORCHILIN, 2005). Um dos maiores desafios no desenvolvimento de sistemas de drug delivery para serem ministrados via tópica está a baixa permeação de substâncias na pele. A maior barreira para a difusão de ativos é o estrato córneo, camada mais superficial da pele, constituída por células agrupadas de forma bastante coesa. O uso de vesículas lipídicas facilita o transporte de ativos sobre a pele (MEZEI; GULASEKHARAM, 1980).

\subsection{LIPOSSOMAS E ÁCIDOS GRAXOS}

Ácidos graxos são moléculas anfipáticas, capazes de se incorporar nas membranas lipídicas e alterar suas propriedades físico-químicas. Quando em água, os sais dos ácidos graxos tendem a formar micelas e não bicamadas, dada a sua geometria cônica (FIGURA 9). A forma protonada do ácido graxo é pouco solúvel e em água não forma micelas.
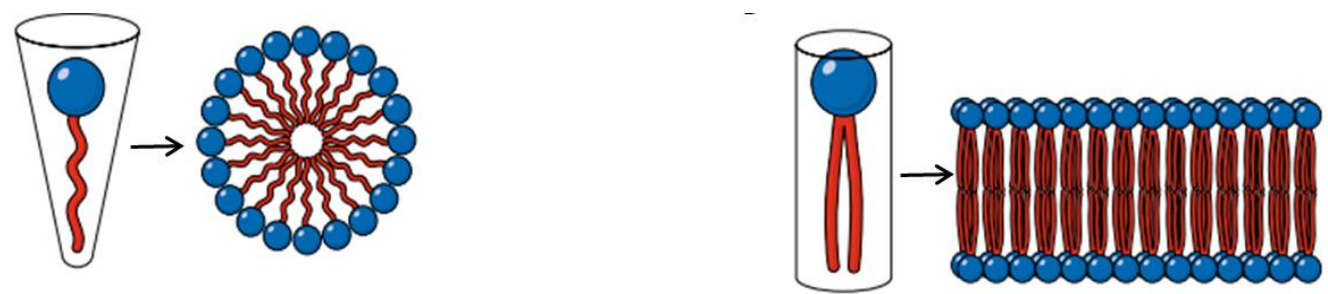

Figura 9-Agregados formados por moléculas anfipáticas de diferentes geometrias.

Dependendo da composição lipídica e de seu estado físico (fase líquido-cristalina, fase gel), a bicamada pode incorporar até $60 \%$ (em mol) de ácidos graxos. A incorporação de até 
mesmo uma pequena quantidade $(1 \% \mathrm{em} \mathrm{mol})$ nas membranas pode levar a alterações na permeabilidade transmembranar (CROWE; MCKERSIE; CROWE, 1989).

Os ácidos graxos, devido a sua geometria molecular, induzem um maior grau de curvatura das membranas, aumentando a sua propensão de formar poros. Eles também afetam a espessura da bicamada, podendo levá-la ao rompimento. Todos esses efeitos tendem a aumentar a permeabilidade das membranas. Essas alterações na permeabilidade podem ser usadas como vantagem no desenvolvimento de sistemas drug delivery, favorecendo a liberação do ativo. (JESPERSEN et al., 2012)

Os efeitos que os ácidos graxos exercem sobre a membrana, apesar de serem frequentemente descritos na literatura, ainda não são bem compreendidos. Acredita-se que dependem do tipo de ácido graxo, em especial, do seu grau de insaturação e comprimento da cadeia carbônica. Além disso, sabe-se que esses efeitos observados dependem se o ácido graxo é misturado previamente com os outros componentes que irão formar as bicamadas ou se são adicionados a elas posteriormente, já prontas. No caso de serem adicionados previamente o seu efeito é menor, pois eles conseguem se arranjar e se adaptar espacialmente com todos os demais lipídios da membrana durante sua formação. No caso de serem adicionados posteriormente, os ácidos graxos induzem um efeito maior de rompimento das membranas, dificultando um possível rearranjo dos demais lipídios da bicamada para compensar as alterações na sua curvatura (AROURI; MOURITSEN, 2013).

Os sais dos ácidos graxos são capazes de formar agregados micelares em concentrações acima de sua concentração micelar crítica (CMC) e são incorporados nas bicamadas tanto na sua forma protonada quanto na forma dissociada. A incorporação de ácidos graxos pode levar a formação de diferentes estruturas de agregados, com regiões heterogêneas na membrana em função da composição lipídica (DAVIDSEN; MOURITSEN; JØRGENSEN, 2002).

Uma das principais características das vesículas contendo ácidos graxos é a sua dinâmica, induzida por mudanças nas condições do meio. $\mathrm{O}$ fato de que diferentes agregados com ácidos graxos podem ser formados apenas se alterando seu estado de protonação e concentração é uma excelente oportunidade para estudar as propriedades físico-químicas das diferentes estruturas (MORIGAKI; WALDE, 2007).

Os benefícios dos lipossomas relacionados à sua capacidade de encapsulação/ liberação de ativos, de impedir a desidratação e promover a regeneração de lipídios da 
pele, os tornam ingredientes inovadores e efetivos na área de cosméticos. Em geral, os lipossomas são mais compatíveis com a estrutura da pele do que as emulsões convencionais.

O estudo de lipossomas contendo LA, com potencial para aplicação dermatológica na prevenção e tratamento da acne, pode auxiliar na elucidação do papel do LA na estrutura dos lipossomas, modulação de suas propriedades de retenção de ativos e contribuir com uma alternativa ao combate à acne. 


\section{OBJETIVOS}

\subsection{OBJETIVOS GERAIS}

Desenvolver e caracterizar lipossomas contendo ácido láurico, que possuam potencial para uso na área de cosméticos.

\subsection{OBJETIVOS ESPECÍFICOS}

- Produzir lipossomas de diferentes composições, contendo ácido láurico;

- Realizar caracterização físico-química dos lipossomas por métodos como: medida do tamanho médio de partículas/ distribuição de tamanhos, eficiência de encapsulação e determinação de temperatura de transição de fase (Tm);

- Verificar o efeito do pH sobre as características físico-químicas dos lipossomas contendo ácido láurico. 


\section{MATERIAIS E MÉTODOS}

\subsection{MATERIAIS}

O fosfolipídeo 1,2-dipalmitoil-sn-glicero-3-fosfocolina (DPPC) (FIGURA 10a) foi obtido da Avanti Polar Lipids e o ácido láurico (LA) (FIGURA 10b) da Sigma Aldrich. As membranas de policarbonato com diâmetro de poro de $100 \mathrm{~nm}$, utilizadas para a extrusão, eram da Whatman (Nucleopore Track-Etch Membrane). O Tris Base (Trizma Hydrochloride), a 5(6)-Carboxifluoresceína (CF), a resina Sephadex G-25 e o ácido perclórico 70\% eram da Sigma Aldrich. Os ácidos clorídrico, ascórbico, acético, bórico e fórmico e o hidróxido de sódio eram da Merck. O 4-trimetilamônio-2,2,6,6-tetrametilpiperidina-1oxiliodeto, CAT1, e o pireno tetrasulfonato de sódio, PTS, eram da Molecular Probes. Os solventes clorofórmio e metanol eram reagentes de grau analítico da J. T. Baker Chemicals. A CF foi purificada segundo o método de Weinstein et al., 1977.

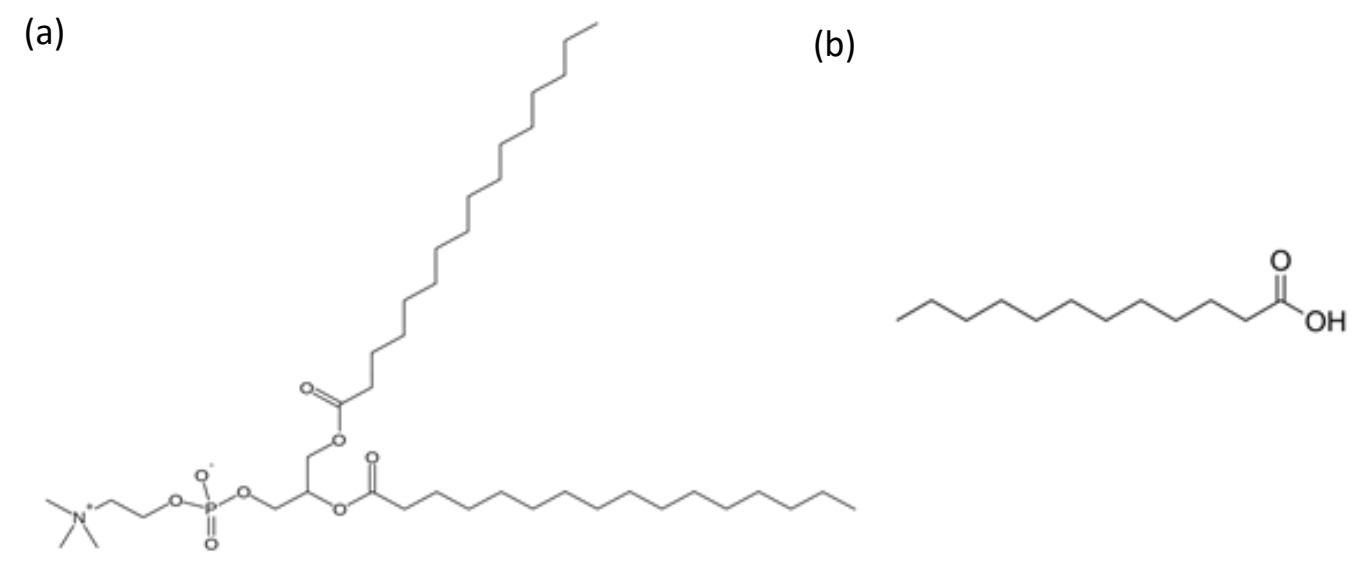

Figura 10- Estruturas do (a) DPPC e do (b) ácido láurico.

\subsection{PREPARO DOS LIPOSSOMAS}

Os lipossomas foram preparados pelo método de hidratação do filme lipídico (FIGURA 11). A fração de LA nas amostras variou de 0 a $50 \%$ em moles da concentração total. Desta forma, obtivemos as seguintes preparações: DPPC, DPPC:LA 90:10, DPPC:LA 80:20, DPPC:LA 70:30, DPPC:LA 60:40 e DPPC:LA 50:50.

O DPPC e o LA foram pesados nas quantidades desejadas em um tubo de ensaio de fundo largo e solubilizados com uma mistura clorofórmio:metanol 3:2. Em seguida, o tubo de 
ensaio com os lipídios foi submetido a um fluxo de $\mathrm{N}_{2}$ juntamente com rotação manual, volatilizando a mistura de solventes orgânicos e formando um filme fino seco, aderido à parede do tudo. Os filmes foram colocados em um dessecador sob vácuo por cerca de 1 hora para garantir a retirada completa dos solventes.

Para ressuspender o filme e formar os lipossomas, adiciona-se o volume desejado da solução tampão com pH de interesse ou solução contendo CF, PTS ou CAT1 e agita-se a suspensão em vórtex. Desta forma obtemos as chamadas MLV, que são vesículas multilamelares, com diâmetros variados.

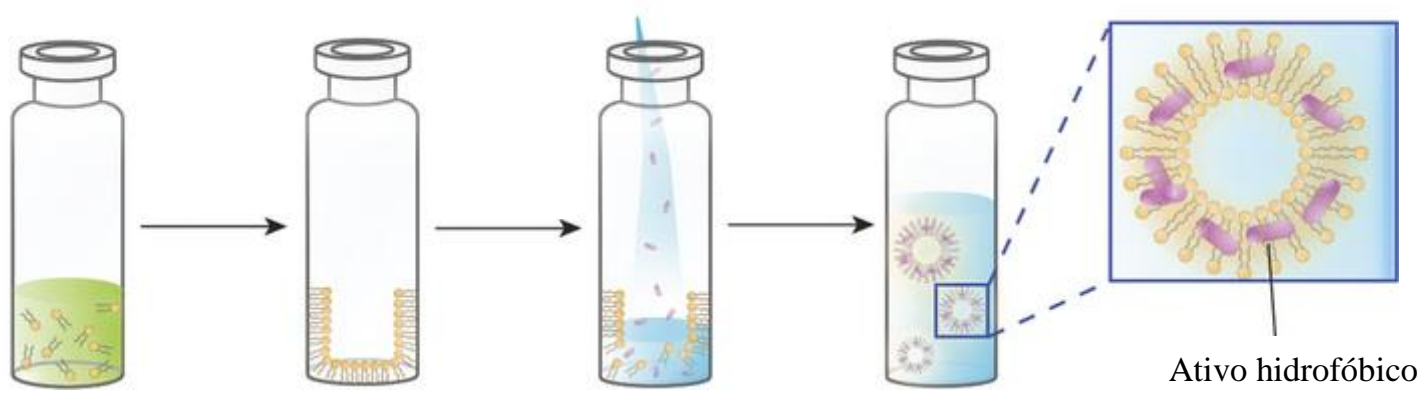

Figura 11- Esquema de preparo de vesículas pelo método de hidratação do filme lipídico.

Para formar vesículas unilamelares grandes, LUV, a suspensão de MLV foi submetida a um processo chamado de extrusão (FIGURA 12). Na extrusão, as vesículas são forçadas a passarem por uma membrana, neste caso com tamanho de poro de $100 \mathrm{~nm}$, repetidas vezes (11 passagens quando utilizadas duas membranas). Este processo foi realizado a $60^{\circ} \mathrm{C}$, temperatura acima da temperatura de transição de fase do DPPC.

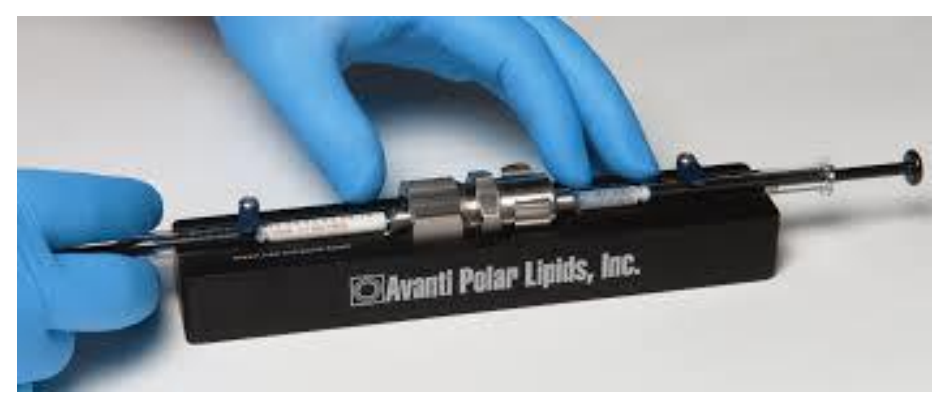

Figura 12- Extrusão de MLV para se obter vesículas unilamelares grandes, LUV.

\subsection{ESTABILIDADE DAS VESÍCULAS COM ÁCIDO LÁURICO}

O diâmetro hidrodinâmico define o diâmetro de uma esfera rígida que difunde com a mesma velocidade da partícula que está sendo examinada pelo espalhamento de luz dinâmico. 
Desta forma, o Dh representa o diâmetro médio de uma partícula dentro da sua dinâmica de difusão, considerando a camada de solvatação (ZAMARION, [s.d.]).

O índice de polidispersidade (PdI) é a razão que correlaciona a variância amostral com o quadrado do diâmetro hidrodinâmico médio das partículas em uma curva de distribuição (EQUAÇÃO 1).

$$
P d I=\left(\frac{\sigma}{d}\right)^{2} \quad(\text { Equação1) }
$$

onde $\sigma^{2}=$ variância $d=$ diâmetro hidrodinâmico médio

Partículas suspensas em um meio líquido nunca estão em estado estacionário, movimentando-se constantemente. Esse movimento, denominado movimento Browniano, ocorre devido à colisão das moléculas do líquido que circundam a partícula. Partículas maiores se movimentam mais lentamente que as menores em uma mesma temperatura (ZAMARION, [s.d.]).

A relação entre o tamanho e a velocidade do movimento Browniano da partícula é definida pela Equação de Stokes-Einstein. Essa medida é feita com a iluminação das partículas com um laser e analisa a intensidade de flutuação do espalhamento de luz. O aparelho possui um correlator que mede o grau de similaridade entre dois sinais em um período de tempo. A função de correlação varia conforme o tamanho da partícula e assim que a função de correlação é medida, essa informação é utilizada para calcular a distribuição de tamanhos (JIN et al., 1999).

As partículas, quando iluminadas, possuem a característica de espalharem luz, caracterizando o movimento Browniano (MANZINI, 2011). Assim, o espectro de luz que atravessa uma amostra será composto de áreas claras e escuras, onde não há luz detectada. As áreas claras ocorrem onde o espalhamento de luz causado pelas partículas possui a mesma fase de onda, resultando em uma interferência construtiva. As áreas escuras ocorrem onde as ondas de luz, causadas pelo espalhamento, são destrutivas e cancelam umas às outras (JIN et al., 1999). O pontilhado resultante das áreas claras e escuras causadas pelo espalhamento de luz que atravessa uma suspensão se moverá devido ao movimento das partículas variando com certa intensidade e irá caracterizar esse movimento com uma flutuação da intensidade (MANZINI, 2011). 


\subsubsection{Medidas do Diâmetro Hidrodinâmico e do Índice de Polidispersidade}

As medidas foram realizadas em um aparelho Zetasizer Nano ZS, Malvern Instruments Ltd.

Para estes ensaios foram utilizadas amostras de LUV com concentração total final de 0,5 mM de lipídios em soluções de tampão Borato pH 9,0, Tris- $\mathrm{HCl}$ pH 7,4, Acetato pH 5,0 e Formiato pH 3,0, todas na concentração $10 \mathrm{mM}$.

O Dh e o PdI dos lipossomas foi verificado por 30 dias, período no qual as amostras ficaram incubadas a $25{ }^{\circ} \mathrm{C}$ para mimetizar as condições ambientes de um produto em prateleira.

\subsection{CALORIMETRIA DIFERENCIAL DE VARREDURA}

Os fosfolipídios constituintes de uma determinada membrana são caracterizados por uma temperatura de transição da bicamada (Tm), na qual a membrana passa de uma fase gel $\left(\mathrm{L}_{\beta}\right)$, para a fase líquido-cristalina $\left(\mathrm{L}_{\alpha}\right)$. Ou seja, as cadeias hidrocarbônicas dos lipídios que antes estavam ordenadas passam para um estado de movimentos mais livres e os radicais hidrofílicos tornam-se mais hidratados, resultando em um modelo mais fluído (FIGURA 13)(LEWIS et al., 2008).

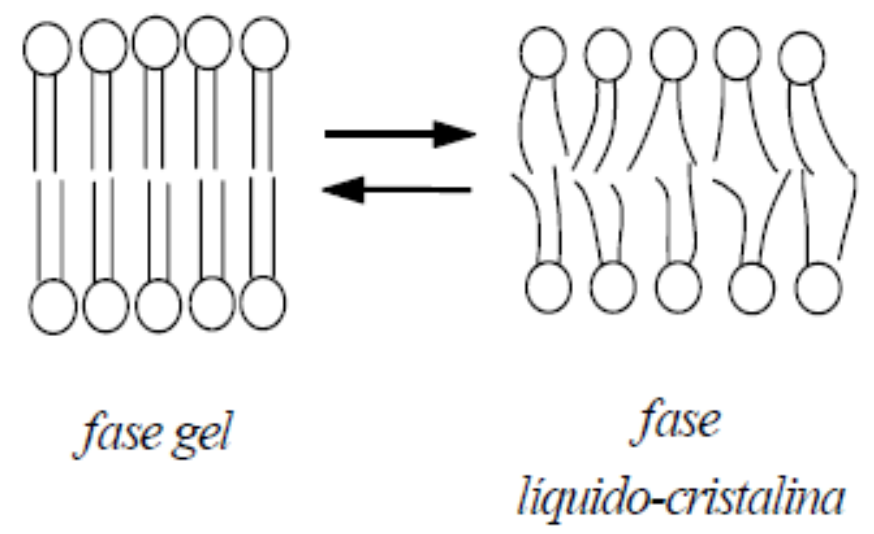

Figura 13- Membrana na fase gel e depois na fase líquido-cristalina, acima da tem0peratura de transição de fase.

A presença do ácido láurico na bicamada dos lipossomas pode causar perturbações e alterar a sua fluidez, modificando a temperatura de transição de fase do DPPC. Uma das técnicas mais utilizadas para verificar estas propriedades é a Calorimetria Diferencial de Varredura (DSC). Além da Tm, o DSC também permite obter valores de entalpia e da cooperatividade da transição de fase, que é proporcional à medida da largura a meia altura 
$\left(\Delta^{1} / 2\right)$ dos picos em curvas DSC. Uma perda na cooperatividade de um sistema, ou seja, alargamento do pico corresponde a um decréscimo na quantidade média de lipídios que transitam uniformemente de um estado a outro para um dado valor ou intervalo de temperatura (VAN EKEREN, 2003).

Um equipamento de DSC (FIGURA 14) consiste em dois pequenos compartimentos (celas) idênticos que são aquecidos eletricamente a uma taxa constante. Uma das celas é preenchida com a solução que contém a amostra de interesse (proteína, lipossoma, etc) e a outra cela é preenchida geralmente com água ou com o tampão utilizado para preparar a amostra. As celas são mantidas à pressão atmosférica ou, em alguns casos, sob pressão de gás inerte para inibir a formação de bolhas durante o processo de aquecimento. Durante o experimento, potência é fornecida pelo aquecedor principal para aumentar a temperatura das celas a uma taxa estacionária, enquanto que diferenças de temperatura entre as celas de referência e de amostra $\left(\Delta \mathrm{T}_{1}\right)$, e entre as células e a câmara adiabática $\left(\Delta \mathrm{T}_{2}\right)$ são monitoradas. Através de circuitos de resposta, um aquecedor/resfriador localizado na câmara adiabática permite a esta atingir a mesma temperatura das celas e aquecedores de resposta localizados nas celas compensam qualquer diferença de temperatura entre elas durante a varredura. Um computador controla a potência térmica dissipada nas celas e câmara adiabática e faz a aquisição dos dados (MELO, 2010).

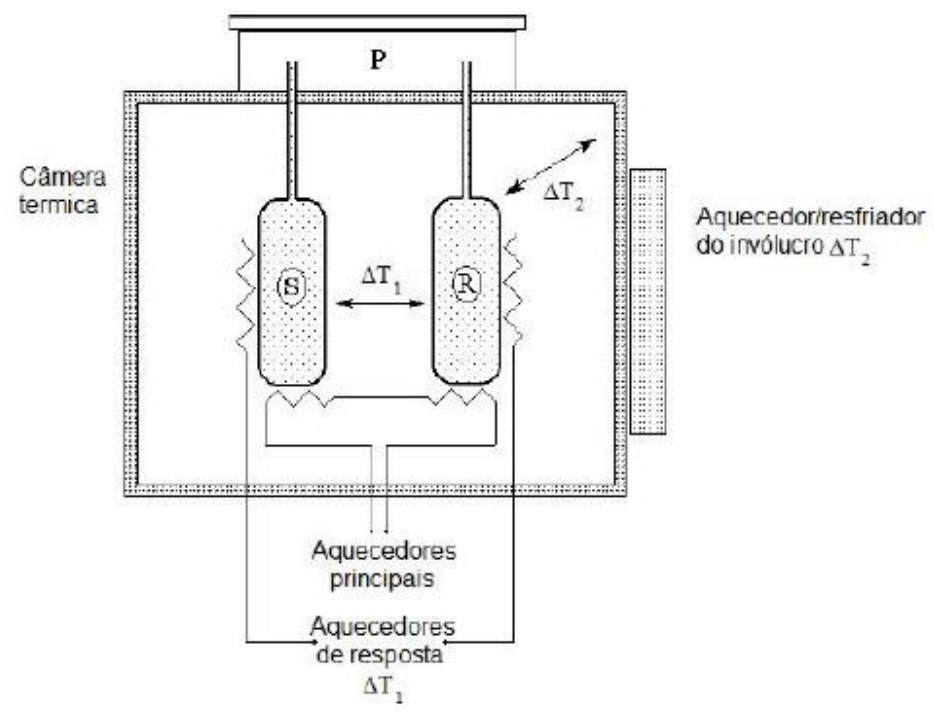

Figura 14- Calorímetro Diferencial de Varredura.

Ao longo da varredura, em um intervalo que não contém nenhuma transição de fase, as temperaturas das celas variam linearmente com o tempo na mesma taxa de aquecimento e a 
diferença de temperatura entre as celas é zero. Isso se reflete de maneira ideal em uma linha de base horizontal reta. Se ocorrer alguma mudança no sistema, a temperatura da cela com a amostra muda significativamente em relação à cela de referência e, para manter a temperatura de ambas as celas, o excesso de energia em forma de fluxo de calor deve ser compensado pelos aquecedores (LEWIS et al., 2008).

\subsubsection{Determinação da Tm e Cooperatividade por DSC}

As determinações de Tm foram realizadas em um calorímetro MicroCal VP-DSC Microcalorimeter, Malvern Instruments Ltd. As amostras de LUV tinham concentração total de $1 \mathrm{mM}$ em soluções tampão 10 mM, nos pHs 9,0 (tampão borato), 7,4 (tampão Tris-HCl), 5,0 (tampão acetato) e 3,0 (tampão formiato). As suspensões lipossomais $(0,5173 \mathrm{~mL}$ ) foram colocadas no calorímetro com auxílio de uma seringa e submetidas à variação de temperatura de 15 a $60^{\circ} \mathrm{C}$, com uma velocidade de varredura de $30^{\circ} \mathrm{C} /$ hora. Como referência foi utilizada água desmineralizada. Para o tratamento dos dados foi utilizado o programa Origin 8.5.

\subsection{ESPALHAMENTO DE RAIOS-X A BAIXO ÂNGULO (SAXS)}

O SAXS consiste num processo de espalhamento elástico que ocorre quando os raios-X de alta energia (de comprimento de onda de 1,5 ) atingem um material e interagem com os elétrons do mesmo. Quando existe alta organização a nível atômico, com todas as unidades espalhantes em fase, ocorre um espalhamento cooperativo, que produz um perfil de difração onde as chamadas reflexões de Bragg apresentam uma alta definição. Em um material que apresenta desorganização a nível atômico, as unidades espalhantes estarão fora de fase, o que resulta num espalhamento difuso, ou não-cooperativo, e de baixa intensidade, ocorrendo numa ampla faixa angular (GERBELLI, 2012).

Supondo os centros espalhantes no vácuo, a amplitude de espalhamento é proporcional ao número de moles de elétrons por unidade de volume, ou seja, à densidade eletrônica. Com os centros espalhadores imersos em outro meio, apenas a diferença de densidade eletrônica entre os meios será considerada. No caso de análise de partículas em suspensão ou solvente, o espalhamento é resultante do contraste de densidade eletrônica entre a partícula e o solvente (GONÇALVES, 2008). 


\subsubsection{Medidas de SAXS e Ajuste dos Dados Experimentais}

Para a técnica de Espalhamento de Raios X a Baixo Ângulo (SAXS) foi utilizada uma máquina convencional Nanostar Bruker (com ótica otimizada pela empresa Xenocs) (FIGURA 15) instalada no Laboratório de Cristalografia do Instituto de Física, sob orientação do Prof. Dr. Cristiano Luis Pinto de Oliveira. As medidas foram realizadas pelo aluno Pedro Oseliero.

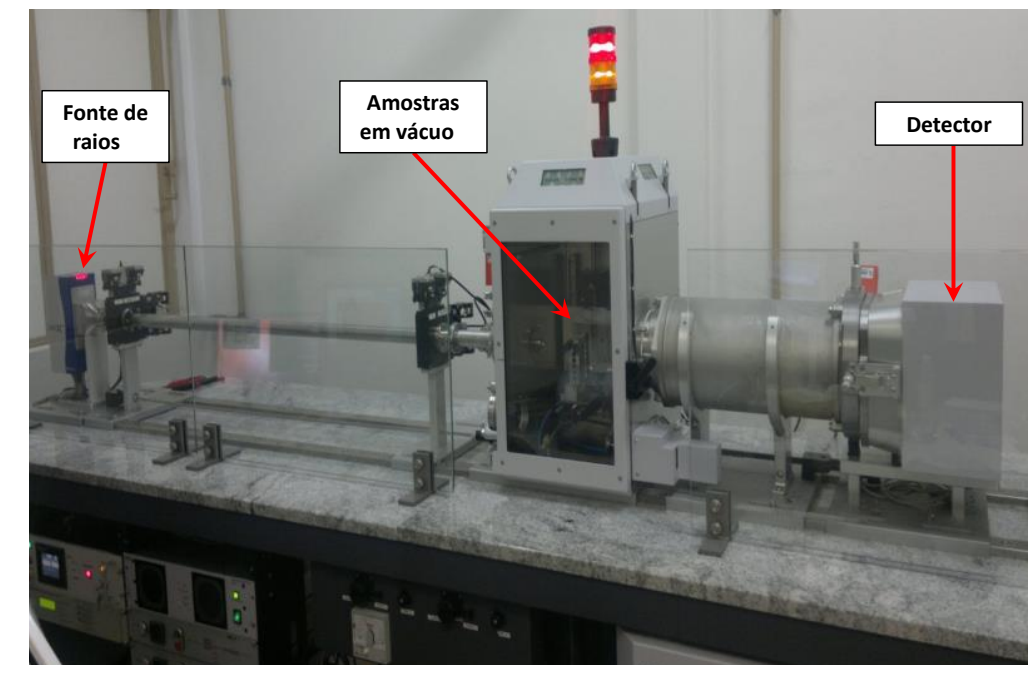

Figura 15- Equipamento Nanostar Bruker utilizado nas medidas de SAXS.

Nestes experimentos foram utilizados capilares de vidro de $1,5 \mathrm{~mm}$ de diâmetro onde foram colocadas amostras de lipossomas de DPPC:LA na concentração total de $10 \mathrm{mM}$,

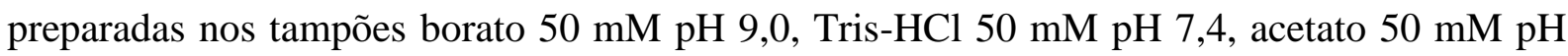
5,0 e formiato $50 \mathrm{mM} \mathrm{pH} \mathrm{3,0.}$

Na realização de experimentos de SAXS utilizou-se um porta amostra que acomodava até 3 capilares de vidro à temperatura ambiente, cerca de $25^{\circ} \mathrm{C}$. O controle das aquisições foi realizado pelo programa interno da máquina onde a cada aquisição são geradas imagens bidimensionais de formato ".gfrm". Para análise desses arquivos foi utilizado o programa SUPERSAXS que permite desde a subtração de fundo até a redução dessas imagens em curvas unidimensionais $(I(q))$ com as respectivas incertezas dos dados experimentais.

\subsubsection{Ajuste das curvas de espalhamento}

A intensidade espalhada para uma fase lamelar pode ser descrita pela Equação 2: 


$$
I(q)=\frac{S(q)\left|P(q)^{2}\right|}{q^{2}} \quad(\text { Equação2) }
$$

onde $q$ é o módulo do vetor de espalhamento de raios $\mathrm{X}, S(q)$ refere-se à função do fator de estrutura e $P(q)$ ao fator de forma.

O fator de forma depende apenas do espalhamento produzido por uma única bicamada, enquanto o fator de estrutura corresponde ao espalhamento gerado por um conjunto de bicamadas, espaçadas periodicamente com orientação aleatória. Para descrever o fator de forma foi utilizado o modelo de deconvolução de gaussianas (4 gaussianas).

\subsubsection{Fator de Estrutura}

Os parâmetros que descrevem a estrutura e flexibilidade da bicamada lipídica podem ser determinados pelos parâmetros estabelecidos no ajuste das curvas experimentais, sendo os principais: periodicidade lamelar (repetição de um padrão que é formado pela bicamada + camada aquosa), número de camadas correlatas e parâmetro de Caillé.

\subsubsection{Fator de Forma}

A densidade do contraste eletrônico da bicamada é descrita pelo fator de forma. Através do modelo de deconvolução de gaussianas, pode-se descrever a variação do contraste eletrônico de maneira mais suave, como observado na Figura 16.

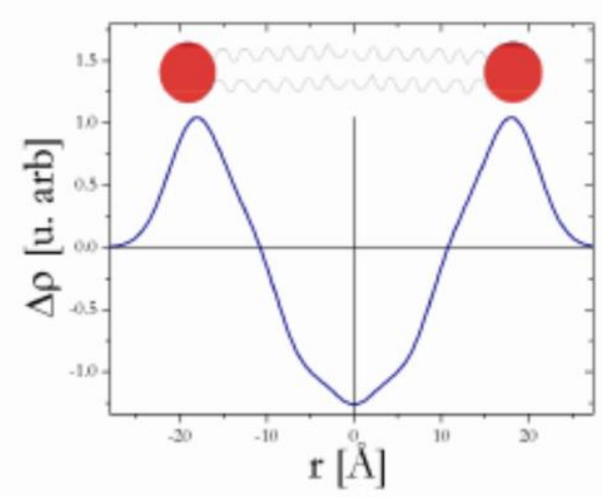

Figura 16- Modelo de deconvolução de gaussianas. 


\subsubsection{Espessura da Bicamada}

Através do ajuste dos dados experimentais de espalhamento, obtemos a periodicidade lamelar e o perfil de densidade eletrônica da bicamada. O pico representa a posição das cabeças polares e o centro corresponde ao meio da bicamada (FIGURA 17). Uma função gaussiana descreve o contraste de densidade eletrônica da região e, tomando-se a distância do centro da bicamada até o ponto que corresponde à largura a meia altura da gaussiana, obtémse a metade da espessura da bicamada (GERBELLI, 2012).

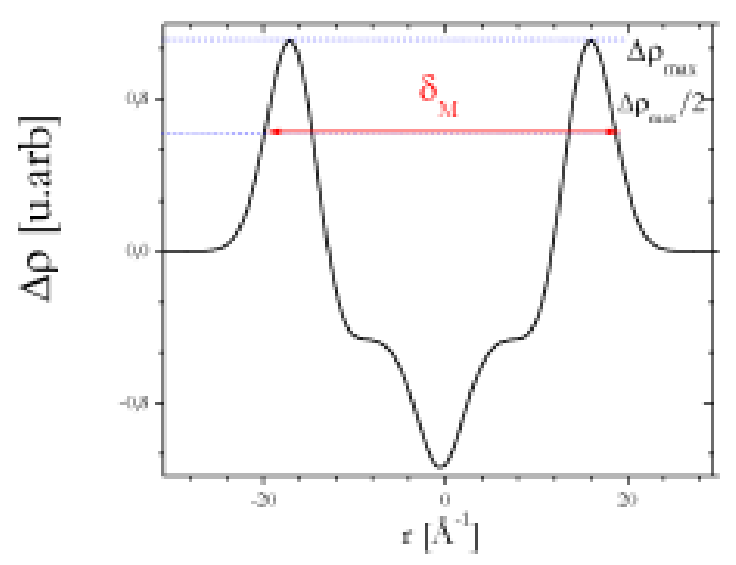

Figura 17- Perfil de densidade eletrônica da bicamada, indicando em vermelho a espessura da bicamada.

\subsection{CRIO-MICROSCOPIA ELETRÔNICA DE TRANSMISSÃO}

O microscópio eletrônico de transmissão é um microscópio de luz invertido, no qual um feixe de elétrons incide sobre a amostra. Apenas amostras em seções finas podem ser estudadas, uma vez que os elétrons não penetram profundamente na matéria (BIBI et al., 2011).

O contraste entre as vesículas e o fundo ocorre por espalhamento de elétrons pela matéria e é diretamente proporcional ao número atômico. Sendo assim, não existe emprego de agente contrastante nesta técnica. A imagem observada é a projeção em duas dimensões de um objeto de três dimensões (FIGURA 18). A mesma é obtida quando um feixe de elétrons atravessa uma vesícula tangencialmente ao seu volume (KUNTSCHE; HORST; BUNJES, 2011). 
Os elétrons interagem com as moléculas que constituem a vesícula produzindo um contraste mais elevado nas suas bordas que, consequentemente, é visualizada como um anel cinza.

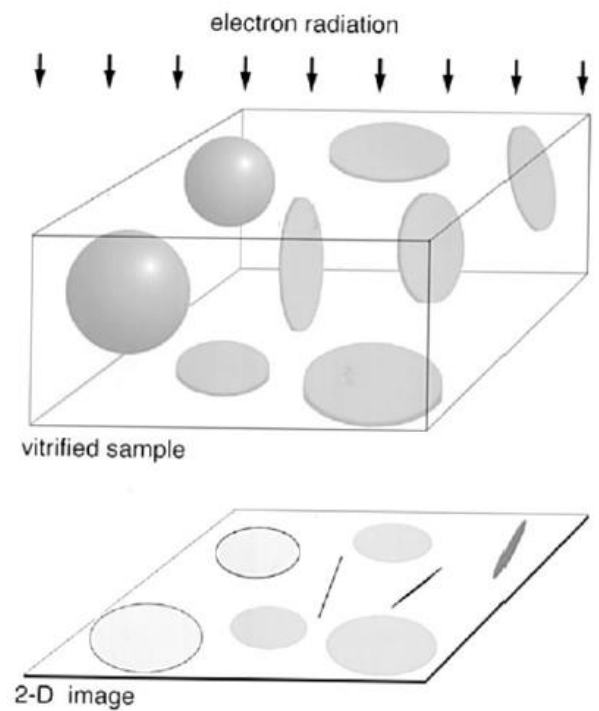

Figura 18- Exemplo de imagem 2-D para uma amostra vitrificada.

\subsubsection{Preparo das Amostras para Crio-TEM e Aquisição das Imagens}

Os estudos de Crio-Microscopia Eletrônica de Transmissão foram efetuados para a caracterização estrutural das vesículas com ácido láurico. Para a análise Crio-TEM foram utilizadas amostras de vesículas de DPPC, DPPC:LA 70:30 e DPPC:LA 50:50 com concentração total de lipídio de 2,5 mM nos tampões acetato $0,01 \mathrm{M} \mathrm{pH} \mathrm{5,0} \mathrm{e} \mathrm{tris-} \mathrm{HCl}$ 0,01M pH 7,4. Foi depositada uma gota de $3 \mu \mathrm{L}$ da amostra em grade Lacey de cobre (300 mesh) revestida por carbono (TED Pella) previamente submetida a um tratamento de descarga luminescente utilizando um sistema easiGlow (Pelco) com $15 \mathrm{~mA}$ de corrente negativa por 10 s. As amostras foram preparadas em ambiente controlado, com temperatura e umidade ajustado para $22^{\circ} \mathrm{C}$ e $100 \%$, respectivamente, num sistema de vitrificação automatizado (Vitrobot Mark IV, FEI). Os parâmetros do Vitrobot seguiram um tempo de blot de 3s, força de blot de 0 e 20 segundos de tempo de espera antes do início do blot. As amostras foram analisadas em condição de baixa dosagem, com uma gama de desfocagem de -2 a $-4 \mu \mathrm{m}$, utilizando um equipamento Jeol JEM-2100 operando a $200 \mathrm{kV}$. As imagens foram adquiridas usando uma câmera F-416 CMOS (TVIPS, Alemanha). A preparação das amostras e aquisição de dados foram realizados no Laboratório de Microscopia Eletrônica 
(LME)/Laboratório Nacional de Nanotecnologia (LNNano) pelo Dr. Alexandre Cassago (FIGURA 19).
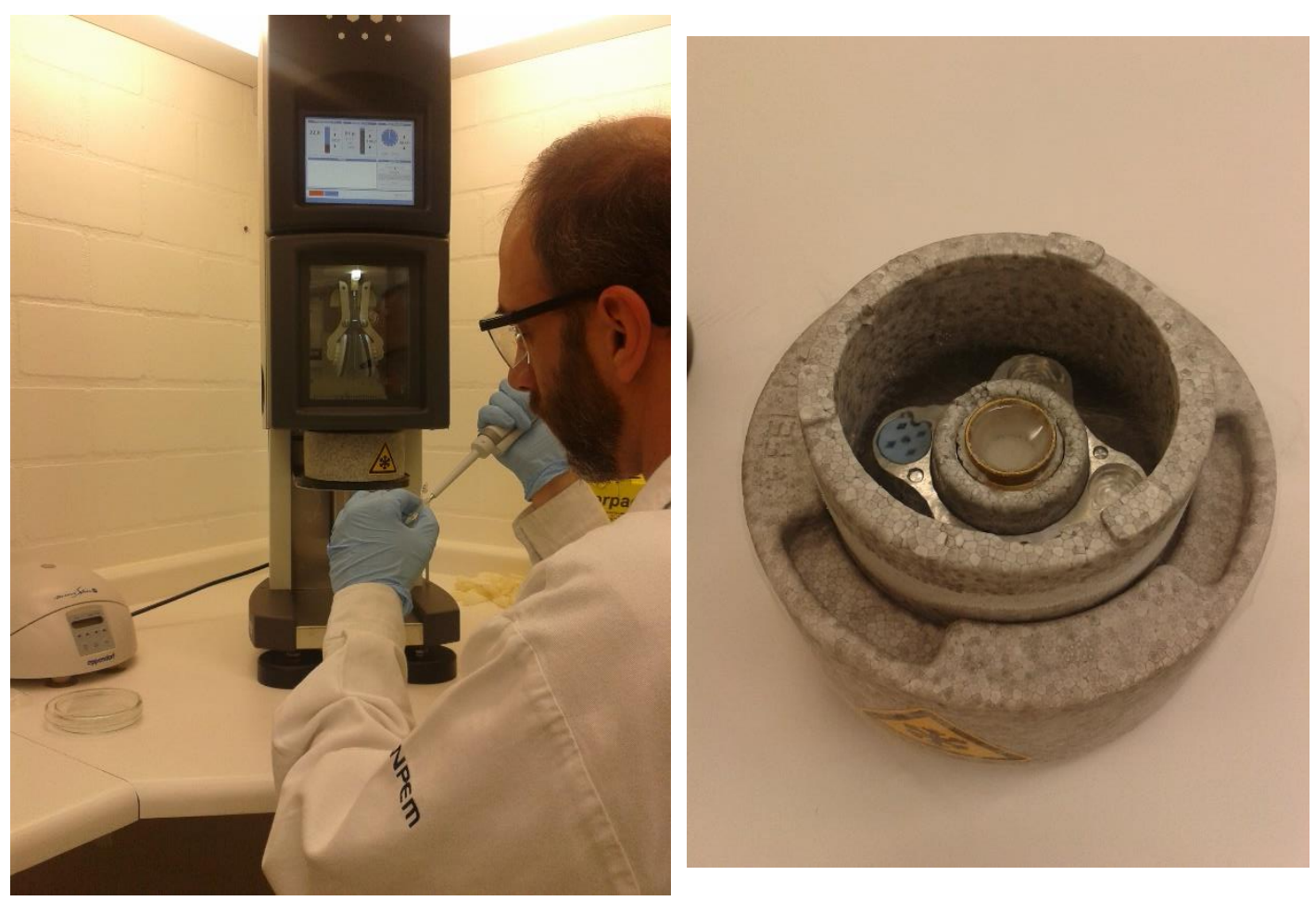

Figura 19- Preparo das amostras para Crio-TEM pelo Dr. Alexandre Cassago no LNNano- Campinas.

\subsection{ENCAPSULAMENTO DE SONDAS NO COMPARTIMENTO AQUOSO INTERNO DAS LUV}

\subsubsection{Encapsulamento de Sondas Fluorescentes}

A luminescência é caracterizada pela emissão de fótons com energia na região do UV, visível ou infravermelho de uma espécie eletronicamente excitada. Como casos particulares da luminescência, temos a fluorescência e a fosforescência. Para estes casos, a absorção de um fóton é o modo de excitação que leva a espécie que absorveu para um estado eletrônico excitado.

Na fluorescência o estado excitado é singlete, assim, o elétron no orbital excitado está pareado com o elétron que se encontra no orbital do estado fundamental. O retorno para o estado fundamental é uma transição permitida e a emissão ocorre com velocidade na ordem de $10^{8} \mathrm{~s}^{-1}$ (MANZINI, 2011). 
Os espectros de fluorescência são apresentados como espectro de emissão, que é uma curva de intensidade de fluorescência versus comprimento de onda $(\lambda)$. O espectro de emissão é sensível à estrutura química do fluoróforo e à polaridade do solvente no qual ele está dissolvido (PUC-RIO, 2006).

A CF (5(6)- carboxifluoresceína) (FIGURA 20) sofre um processo de auto-supressão da fluorescência em altas concentrações e é muito utilizada em estudos de atividade de moléculas sobre os lipossomas. Em concentrações baixas, utilizando-se um máximo de excitação em 490 nm, a CF tem um máximo de emissão em $520 \mathrm{~nm}$. Utilizamos a CF também em experimentos nos quais pretendemos verificar a porcentagem de incorporação da sonda no compartimento aquoso interno dos lipossomas. A vantagem de se utilizar a CF é que esta sonda é carregada negativamente, dependendo do $\mathrm{pH}\left(\mathrm{pka}_{1}=4,2 \pm 0,2 ; \mathrm{pka}_{2}=4,9 \pm 0,1\right.$ e $\left.\mathrm{pka}_{3}=6,7 \pm 0,1\right)$. Isto permite a incorporação em lipossomas sem que haja vazamento da sonda fluorescente encapsulada no espaço aquoso interno para o compartimento aquoso externo (ASCHI et al., 2008).

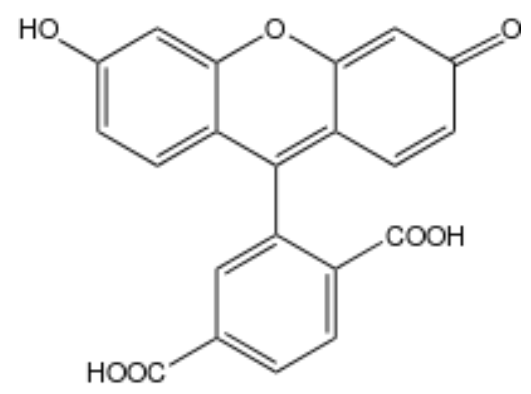

Figura 20- Estrutura da molécula de 5(6)-carboxifluoresceína.

Com a CF, para que ocorra a auto-supressão, há transferência de energia entre os monômeros de CF no estado excitado através de colisões com outros monômeros ou dímeros no estado fundamental. A concentração de CF utilizada neste trabalho foi de $2 \mathrm{mM}$ para a qual não há auto-supressão e a CF já está bastante diluída.

O PTS (Figura 21) é uma sonda fluorescente contendo quatro grupos carregados negativamente e que pode ser utilizada em vários $\mathrm{pHs}$ porque o $\mathrm{pKa}$ dos grupos sulfonatos são muito baixos (pka< 1$)$ e o PTS mantém 4 cargas negativas numa faixa de pH bastante ampla (SANTOS et al., 2007). 
<smiles>O=[N+]([O-])c1cc([O-])c2ccc3c([O-])cc([O-])c4ccc1c2c34</smiles>

Figura 21- Estrutura da molécula do Pireno Tetrasulfonato de Sódio.

\subsubsection{Vesículas com CF/PTS e Medidas de Fluorescência}

Para estes experimentos foi preparada uma solução $2 \mathrm{mM}$ de CF em tampão Tris-HCl $50 \mathrm{mM}$ pH 7,4 ou $1 \mathrm{mM}$ de PTS em tampão acetato $50 \mathrm{mM} \mathrm{pH} \mathrm{5,0,} \mathrm{dependendo} \mathrm{do} \mathrm{pH} \mathrm{que} \mathrm{se}$ pretendia estudar. Filmes lipídicos DPPC:LA $10 \mathrm{mM}$ foram ressuspendidos em $500 \mu \mathrm{L}$ destas soluções contendo CF ou PTS e as vesículas multilamelares formadas foram extrusadas. Com isso, foram obtidas LUV contendo fluoróforo em seu interior e exterior. Uma coluna de Sephadex G25 médio, com volume de aproximadamente 79,5 $\mathrm{cm}^{3}$ (diâmetro: $1,5 \mathrm{~cm}$, altura: $45 \mathrm{~cm}$ ), foi utilizada para separar os lipossomas contendo CF ou PTS do fluoróforo livre, não encapsulado. O volume de amostra colocada na coluna foi de $300 \mu \mathrm{L}$. Nesta cromatografia de exclusão as LUV, por serem maiores que a CF ou PTS livre, são eluídas primeiro, no volume morto da coluna $\left(\mathrm{V}_{0}\right)$. O fluoróforo livre por sua vez, por ser pequeno, percorre um caminho maior, pois permeia os poros do Sephadex (FIGURA 22) sendo eluído no volume interno da coluna (Vi).
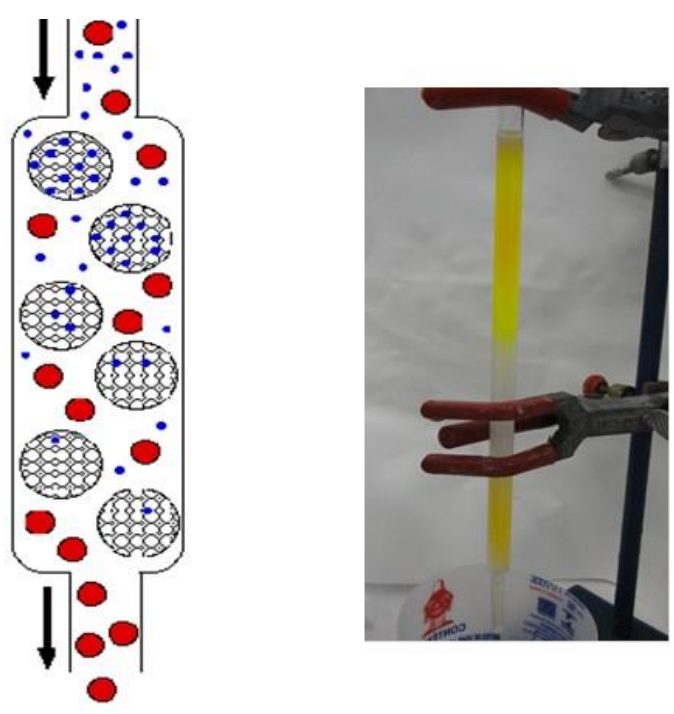

Figura 22- Cromatografia de permeação em gel por exclusão de tamanho. 
Foram coletadas todas as frações eluídas da coluna, de 1 em $1 \mathrm{~mL}$, e a fluorescência de cada fração foi detectada em um Fluorímetro Shimadzu RF-5301PC, com $\lambda$ exc: $490 \mathrm{~nm}$ e $\lambda$ em: $520 \mathrm{~nm}$ para a CF e $\lambda$ exc: $355 \mathrm{~nm}$ e $\lambda \mathrm{em}$ : $405 \mathrm{~nm}$ para o PTS. Para as frações coletadas contendo LUV as medidas de fluorescência foram feitas após a adição de 25 $\mu \mathrm{L}$ de uma solução $10 \%$ de Polidocanol à amostra para evitar dispersão da luz.

Foram feitos gráficos de Fluorescência vs. Volume $(\mathrm{mL})$ eluído para identificar os tubos contendo vesículas (eluídas no Vo) e aqueles com CF ou PTS livre e determinar a porcentagem de encapsulamento nos lipossomas com relação ao total de CF ou PTS (FIGURA 23).

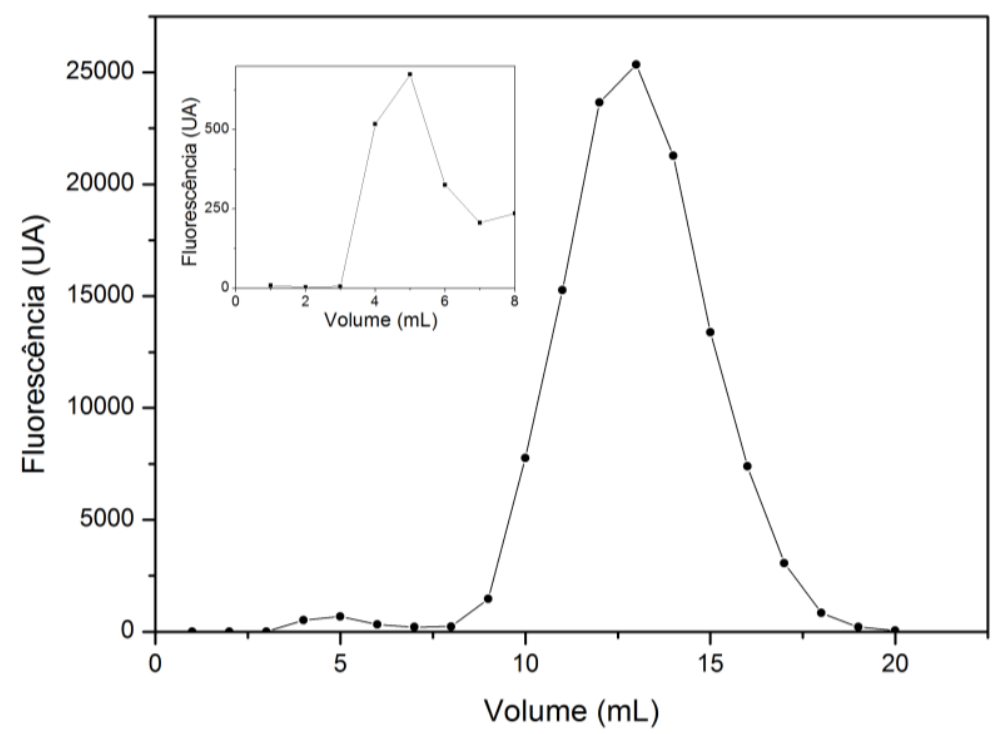

Figura 23- Cromatograma obtido para o encapsulamento de sonda fluorescente. O primeiro e menor pico corresponde às vesículas contendo fluoróforo em seu interior e o pico maior, ao fluoróforo não encapsulado. No inserto é mostrada a fluorescencia das amostras contendo as LUV com CF.

No cromatograma acima são observados dois picos, o primeiro contendo LUV com CF ou PTS (as amostras são turvas) e um segundo pico contendo apenas o fluoróforo livre. Calculamos o número de mols de CF ou PTS em todos os tubos. A porcentagem de encapsulamento (\%) é a razão entre o número de mols do primeiro pico (Vo) dividido pelo número total de mols de CF ou PTS (moles no Vo + moles Vi) multiplicado por 100 (Equação 3).

$$
\% \text { encapsulamento }=\frac{\text { mols } V_{0}}{\text { mols } V_{0}+\text { mols } V_{i}} \times 100
$$


Para cada uma das formulações foi determinada a \% CF $(\mathrm{pH} 7,4)$ ou \% PTS $(\mathrm{pH} 5,0)$ no interior aquoso das vesículas.

\subsubsection{Encapsulamento de Marcador de Spin}

A técnica de EPR é muito específica em suas aplicações, pois depende da presença de centros paramagnéticos (elétron desemparelhados) nos sistemas estudados. Somente moléculas que possuem ao menos um elétron desemparelhado podem ser detectadas por EPR. A técnica se baseia na aplicação de um campo magnético $(\mathrm{H})$, sob a ação do qual os níveis de energia do momento magnético de spin do elétron $(\mathrm{mS}= \pm 1 / 2)$ se tornam divergentes. Aplicando na amostra contendo uma sonda com elétron desemparelhado, e sob a ação de um campo magnético, uma energia adequada na forma de radiação eletromagnética (hv), é possível induzir a transição entre os níveis de energia do momento magnético de spin, que nessa condição não são degenerados $(\mathrm{mS}=+1 / 2 \mathrm{e} \mathrm{mS}=-1 / 2)$ (FIGURA 24) (SCHREIER, 1979). A quantidade de absorção da microonda é proporcional à concentração do marcador na amostra.

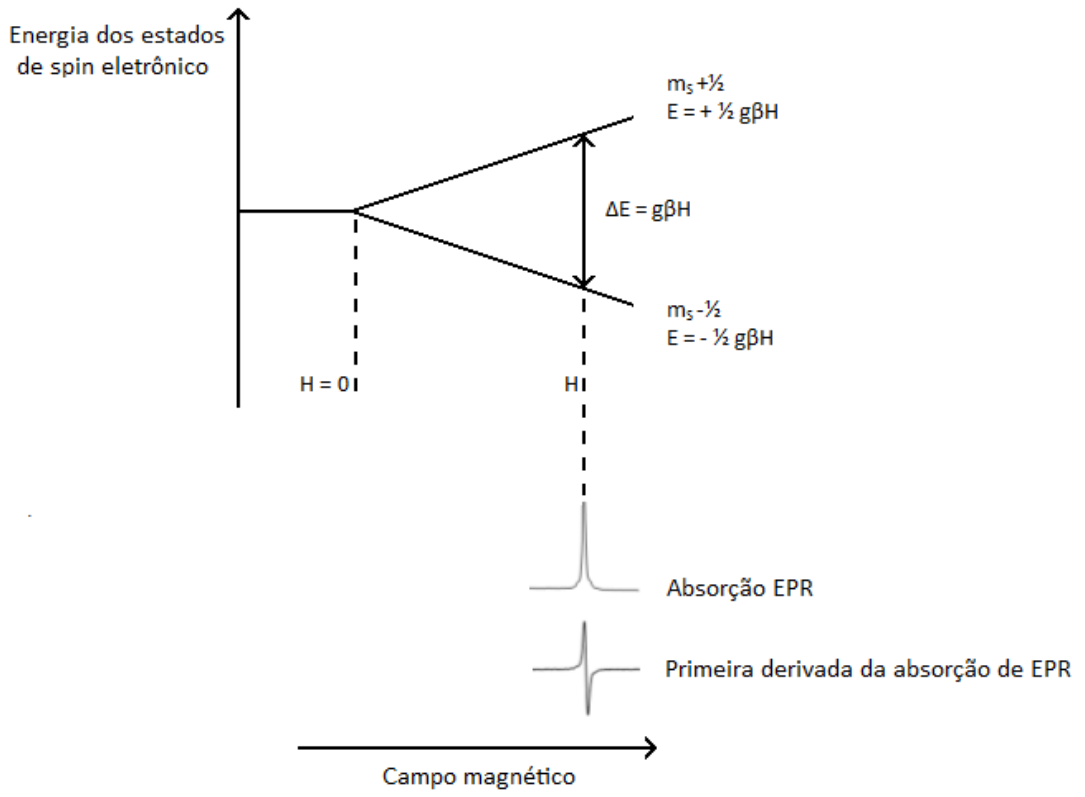

Figura 24- Esquema mostrando o príncipio da técnica de EPR com a transição entre os níveis de energia do momento magnético de spin. 
Os radicais livres mais utilizados como marcadores de spin são os radicais nitróxido. O uso dessas espécies deve-se ao fato de serem estáveis em solventes com diferentes propriedades físico-químicas, em uma ampla faixa de $\mathrm{pH}$ e de temperatura. A estabilização desses radicais deve-se à presença de grupos metila, ligados aos átomos de carbonos vizinhos ao átomo de nitrogênio que estabilizam o radical (SCHREIER, 1979).

Quando um marcador de spin com grupamento N-O está em meio aquoso juntamente com ascorbato (FIGURA 25), ocorre uma rápida redução da espécie paramagnética (FIGURA 26) e o sinal da sonda desaparece.
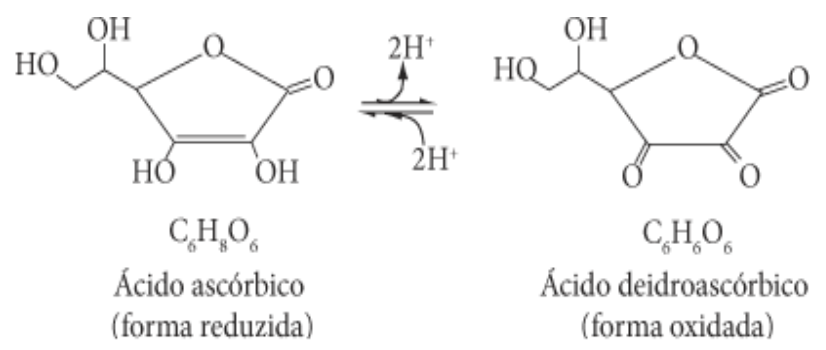

Figura 25- Redução da molécula de ascorbato.

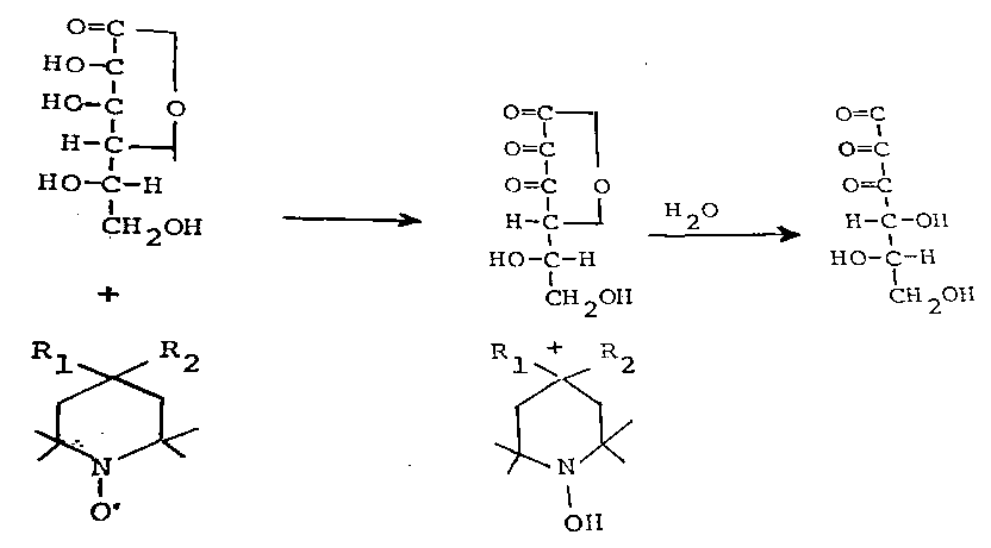

Figura 26- Reação entre o marcador de spin CAT1 e o ascorbato.

\subsubsection{Vesículas com CAT1 e Medidas de EPR}

Para confirmar os resultados obtidos por fluorescência, os experimentos de \% de encapsulamento foram repetidos, por EPR, sob orientação da Profa Dra Shirley Schreier e auxílio do aluno de doutorado Gustavo Battesini, usando como sonda o CAT1 (FIGURA 27) nos pHs 7,4 e 5,0. 


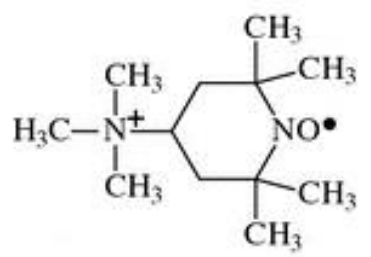

Figura 27- Estrutura molecular do CAT1.

Foram preparadas soluções de CAT1 3,75 mM nos tampões Tris-HCl 50 mM pH 7,4 e Acetato $50 \mathrm{mM}$ pH 5,0. As concentrações de CAT1 em solução foram determinadas usando Tempol como padrão. Também foram preparadas soluções de ácido ascórbico 0,04 M, nestes mesmos tampões, para suprimir o sinal do CAT1 através de uma reação de óxido-redução (Figura 25). Filmes lipídicos de DPPC:LA $10 \mathrm{mM}$ foram preparados, ressuspendidos nas soluções de CAT1, vortexados e extrusados.

Os espectros de EPR foram adquiridos a temperatura ambiente em um espectrômetro Bruker EMX-200 com potência de $5 \mathrm{~mW}$, amplitude de modulação de $1 \mathrm{G}$, varrendo o campo de 16 G centrado em 3455 G. O ganho foi ajustado de acordo com a concentração do marcador na amostra. Para as amostras sem adição de ascorbato, o ganho foi de $2,83 \times 10^{2}$ e após adição de ascorbato, $2,83 \times 10^{3}$.

As amostras de lipossomas contendo CAT1 $(170 \mu \mathrm{L})$ foram colocadas em celas de quartzo planos (Wilmad, EUA) e os espectros de EPR foram registrados; em seguida, adicionou-se $10 \mu \mathrm{L}$ do ácido ascórbico, para reagir com o CAT1 não encapsulado, como mostrado na Figura 26. O ascorbato não deve atravessar a bicamada dos lipossomas por ser muito hidrofílico.

Os espectros foram posteriormente analisados com o software WINEPR (Bruker). A linha obtida foi integrada duas vezes para obtenção do valor de absorção da microonda, proporcional à concentração de CAT1 na amostra, e os valores obtidos normalizados pelo ganho. O volume interno foi calculado pela Equação 4, onde, o sinal total refere-se ao valor normalizado obtido sem a adição do ascorbato, e o sinal final após a adição de ascorbato, com seu valor corrigido de acordo com a diluição.

$$
\text { VEncapsulado }(\mu L)=170 \mu L \times \frac{\text { Sinal Final }}{\text { Sinal Inicial }} \quad \text { (Equaçâo4) }
$$

Conhecendo-se o volume de CAT1 encapsulado foi calculada a porcentagem de encapsulamento (Equação 5): 
$\%$ Encapsulamento $=100 \times \frac{\text { VEncapsulado }(\mu L)}{170 \mu L}$

Os experimentos a seguir, descritos nos itens 3.8 e 3.9 foram realizados durante um estágio realizado na Faculdade de Farmácia da Universidade do Porto em Portugal, juntamente ao grupo de Biotecnologia e Biofísica Molecular, sob a supervisão da Profa. Dra. Salette Reis e da Dra. Cláudia Nunes.

\subsection{LIBERAÇÃO DO ÁCIDO LÁURICO MEDIDA POR DIÁLISE}

Para verificar a cinética de liberação do LA incorporado nas vesículas de DPPC (T $25^{\circ} \mathrm{C}$, condições de prateleira) foram feitos experimentos de diálise. Neste experimento é esperado que apenas o ácido láurico passe pela membrana de diálise e os lipossomas, que são maiores $(100 \mathrm{~nm})$ fiquem em seu interior (FIGURA 28).

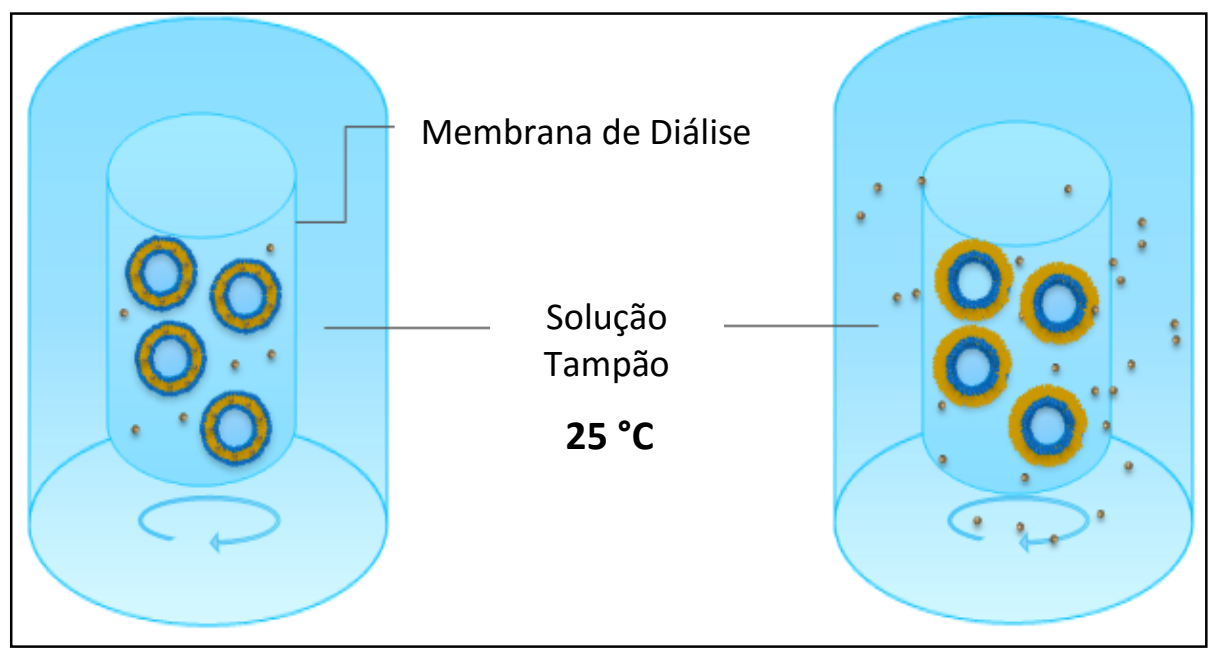

Figura 28- Esquema do experimento de liberação do LA.

Foram preparadas LUV DPPC:LA 0,5 mM nos tampões Tris-HCl $10 \mathrm{mM} \mathrm{pH} \mathrm{7,4} \mathrm{e}$ Acetato $10 \mathrm{mM}$ pH 5,0. Foi colocado $1 \mathrm{~mL}$ de amostra no interior de dispositivos de diálise (Spectra/Por Float-A Lyzer G2 (Spectrum)) (FIGURA 29) com tamanho de poro 3,5 kD e, na parte externa do dispositivo, $6 \mathrm{~mL}$ da mesma solução tampão em que foi preparada a amostra, sob agitação. Para calcular o volume de solução tampão que se deve adicionar na parte externa do dispositivo, foi considerada a solubilidade do LA em água (0,0183 mg/L), uma vez que deve-se garantir que a concentração de LA no sistema seja pelo menos 3 vezes menor ou 
igual $(0,0183 \mathrm{mg} / \mathrm{mL})$ ao seu máximo de solubilidade em água para evitar sua precipitação na fase aquosa.

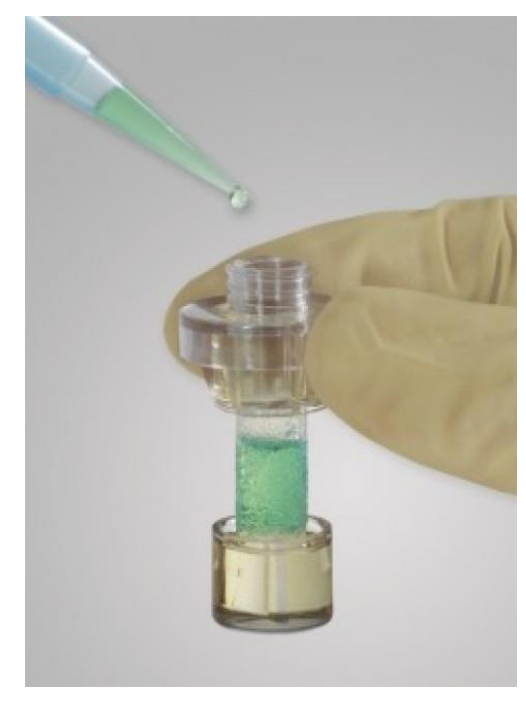

Figura 29- Dispositivo de diálise.

A cada 1 hora, $1 \mathrm{~mL}$ da fração externa foi coletada e colocada em um eppendorf. Para manter as condições de sink, o mesmo volume retirado foi reposto com solução tampão. A coleta foi feita por um período de 3 dias e a quantificação do LA liberado foi feita por espectrometria de massas.

\subsection{DIFUSÃO DO ÁCIDO LÁURICO POR CÉLULA DE FRANZ}

A célula de difusão de Franz (FIGURA 30) é uma célula de difusão estática, de dose finita, onde a pele é montada e a derme fica em contato com uma solução doadora, mimetizando as condições in vivo. A temperatura do sistema deve ser controlada e mantida por um banho termostatizado que envolve a câmara receptora; a distribuição homogênea da temperatura na solução é alcançada pelo emprego de barras magnéticas controladas por agitadores magnéticos externos.

Como membrana para difusão das LUV com LA foi utilizada a pele de orelha de porco, que foi limpa e armazenada em freezer até seu uso.

Antes de realizar os experimentos com as LUV, foi realizado um ensaio piloto, apenas com solução tampão, para verificar a quantidade de LA presente na pele de orelha de porco. 
Os experimentos foram realizados nos $\mathrm{pHs}$ 7,4 e 5,0, usando os tampões Tris- $\mathrm{HCl}$ e Acetato, respectivamente, ambos na concentração de $10 \mathrm{mM}$.

Foram colocados $5 \mathrm{~mL}$ da solução tampão na câmara receptora e $500 \mu \mathrm{L}$ de amostra ou solução tampão na câmara doadora. A célula de Franz foi colocada dentro de um béquer com água a $37{ }^{\circ} \mathrm{C}$. A temperatura se estabilizou em 15 minutos e o tempo de incubação foi de 8 horas, que é considerado o tempo máximo de permanência de um produto na pele. A cada 1 hora foi retirada uma alíquota de $500 \mu \mathrm{L}$ de solução da câmara receptora para quantificar o LA e verificar sua permeação sobre a pele. Para manter as condições de sink, estes mesmos $500 \mu \mathrm{L}$ foram repostos, utilizando as soluções tampão.

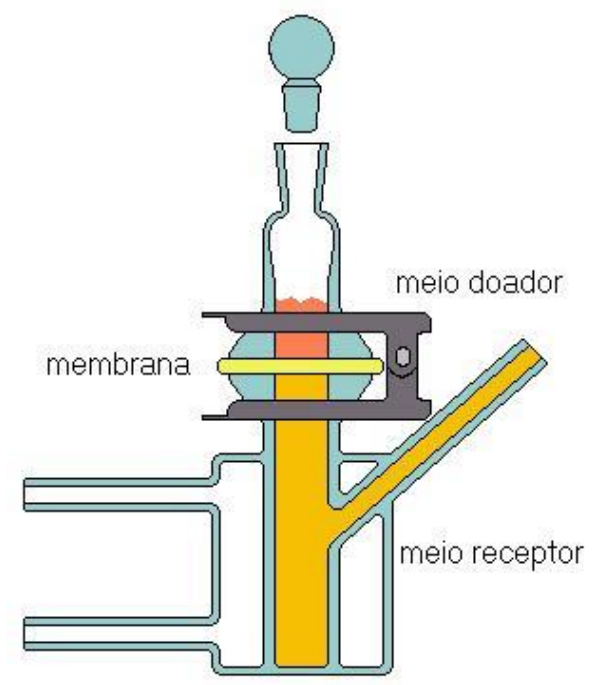

Figura 30- Sistema de difusão de Franz

\subsection{QUANTIFICAÇÃO DOS FOSFOLIPÍDIOS}

Alíquotas das amostras de LUV de DPPC:LA foram adicionadas a tubos de ensaio previamente tratados com $\mathrm{HCl}$ concentrado e foram secas em estufa a $120^{\circ} \mathrm{C}$. Após secagem adicionou-se $0,4 \mathrm{~mL}$ de ácido perclórico $70 \%$ a cada alíquota. Os tubos foram mantidos por 1 hora em um digestor a $180{ }^{\circ} \mathrm{C}$, tempo necessário para mineralizar os lipídios. Após resfriamento à temperatura ambiente, adicionou-se $1 \mathrm{~mL}$ de água e $0,4 \mathrm{~mL}$ de molibdato de amônio $1,25 \%(\mathrm{p} / \mathrm{v})$ às amostras. Os tubos foram agitados num vórtex imediatamente após cada adição. Em seguida, adicionou-se às amostras $0,4 \mathrm{~mL}$ de uma solução de ácido ascórbico $3 \%(\mathrm{p} / \mathrm{v})$, agitaram-se os tubos em um vórtex novamente e as amostras foram mantidas em banho fervente por cerca de 10 minutos. Após esse período os tubos foram resfriados em água 
corrente e a absorbância foi lida em $797 \mathrm{~nm}$. A curva padrão foi feita utilizando como padrão uma solução de $\mathrm{KH}_{2} \mathrm{PO}_{4}$ 0,001 M.

\subsection{QUANTIFICAÇÃO DO ÁCIDO LÁURICO}

Para a quantificação do LA referente aos experimentos de liberação de LA e difusão por célula de Franz foi utilizada a técnica de cromatografia líquida acoplada ao espectrômetro de massas (LC-MS). A análise foi realizada em um sistema Nexera X2 UPLC, consistindo de duas bombas LC-30AD, um degassificador DGU-20A5R, coletor de amostras SIL-30AC e forno CTO-20AC (Shimadzu Corporation, Kyoto, Japão). O sistema de MS era um LCMS8040 triplo quadripolo equipado com fonte de ionização eletrospray (ESI) (Shimadzu Corporation, Kyoto, Japão).

Antes da quantificação, foi necessária extração do LA das amostras de lipossomas. As amostras estavam armazenadas em eppendorfs de 1,5 mL, nos quais foram colocados $200 \mu \mathrm{L}$ de clorofórmio com uma seringa de vidro. Agitaram-se os eppendorfs e a fase orgânica foi retirada e transferida para tubos limpos. A extração foi feita 3 vezes para cada uma das amostras. Em seguida os tubos foram levados a um banho seco a $45{ }^{\circ} \mathrm{C}$ com nitrogênio para que o clorofórmio fosse evaporado e restasse apenas a fase orgânica seca para ser ressuspendida em $500 \mu \mathrm{L}$ de uma mistura acetonitrila:água 80:20 (v/v).

A separação por cromatografia foi realizada utilizando uma coluna C8 de fase reversa Kinetex core-shell (150 x $2.1 \mathrm{~mm} ; 2.6 \mu \mathrm{m}$ particle size; $100 \AA$ ) (Phenomenex, Torrance, CA, USA). A temperatura da coluna foi mantida a $30^{\circ} \mathrm{C}$. A eluição foi realizada no modo isocrático, usando-se acetonitrila:água 80:20 (v/v) em um fluxo de $0.2 \mathrm{~mL} \mathrm{~min}^{-1}$. O volume de injeção foi de $2 \mu \mathrm{L}$ e o tempo total da análise foi de 12 minutos. Como padrão interno, foi utilizado o ácido mirístico, um C14.

O espectrômetro de massas foi operado no modo de ionização negativa (ESI-) e os dados foram adquiridos usando o modo de monitoramento múltiplas reações (MRM) para melhorar a seletividade.

Através de MRM, um íon precursor é selecionado na primeira fase do detector MS (Q1) entre os outros vários íons gerados na fonte de ionização. Este íon específico é destruído através de processo de dissociação induzida por colisão na célula Q2, chamada também de câmara de colisão. Na segunda fase do MS (Q3) um íon produzido é detectado entre os fragmentos deste íon destruído. 
Em análises de amostras cujo composto alvo está presente em quantidades pouco significativas, o uso do LCMS é por vezes inadequado e os níveis de ruído são elevados. Através de LCMS/MS, a análise pode ser realizada sem nenhuma interferência dos íons de fundo presentes devido à seletividade de duas etapas de isolamento de massas.

Em LCMS/MS (MRM) a intensidade do pico do analito é baixa quando comparada a uma análise LCMS no modo SIM (Single Ion Monitoring), porém o LCMS/MS possibilita uma maior sensibilidade devido à melhora dos níveis de ruído e consequente aumento da relação sinal ruído.

Os parâmetros para as análises foram: fluxo de gás de nebulização $\left(\mathrm{N}_{2}\right) 3 \mathrm{~L} \mathrm{~min}^{-1}$, temperatura de dessolvatação $250{ }^{\circ} \mathrm{C}$, temperatura do cone de $400{ }^{\circ} \mathrm{C}$, detector de voltagem $1,76 \mathrm{kV}$, gás de colisão (argônio) $230 \mathrm{kPa}$. A transição m/z 199.30>181.25, correspondente a perda de uma molécula de água do ácido láurico, foi usada para a quantificação. 


\section{RESULTADOS E DISCUSSÃO}

\subsection{ESTABILIDADE DAS VESÍCULAS COM ÁCIDO LÁURICO}

Uma das análises físico-químicas sugeridas para estudar alterações que nem sempre são perceptíveis visualmente em uma formulação é a análise de tamanho de partícula. A análise do perfil da curva de distribuição de partículas, durante um determinado período, permite acompanhar o comportamento das partículas em suspensão, evidenciando fenômenos de instabilidade (AGÊNCIA NACIONAL DE VIGILÂNCIA SANITÁRIA, 2004).

De um ponto de vista terapêutico, é importante demonstrar que as LUV contendo o ativo de interesse são suficientemente estáveis para serem armazenados por um determinado período de tempo e preservarem sua eficácia. A decomposição química dos fosfolipídios (hidrólise ou oxidação) pode levar à instabilidade física das LUV, interferindo no seu uso. Os fosfolipídios podem ser hidrolisados originando os liso-fosfolipídios e ácidos graxos. Os lisofosfolipídios também são alvos de posterior hidrólise (CROWE; MCKERSIE; CROWE, 1989). O método de preparo das vesículas, sua composição e o pH do meio estão diretamente relacionados a sua estabilidade.

Para avaliar a estabilidade das LUV contendo ácido láurico em condições de prateleira $\left(\mathrm{T}=25^{\circ} \mathrm{C}\right)$, seu diâmetro hidrodinâmico $(\mathrm{Dh})$, assim como a polidispersidade $(\mathrm{PdI})$, foram avaliados por um período de 30 dias de incubação com medidas realizadas a cada 5 dias.

Um PdI com valor igual ou abaixo de 0,2 indica uma faixa estreita de distribuição dos tamanhos de partícula, indicando maior estabilidade. Valores menores que 0,05 são geralmente obtidos com amostras muito monodispersas. Valores maiores que 0,7 indicam que a amostra tem uma distribuição de tamanho muito ampla e provavelmente não é adequada para medidas de DLS. Se tanto o PdI quanto o Dh mantiverem seus valores durante um determinado período de tempo, a formulação geralmente é considerada fisicamente estável (KLANG et al., 2012). Desta forma, estabilidade física das LUV foi expressa como o período de tempo no qual o tamanho das vesículas se manteve próximo a $100 \mathrm{~nm}$ (tamanho inicial da preparação), com um aumento máximo do PdI de 0,2 (JIN et al., 1999). Para LUV DPPC:LA em pH 9,0 foram obtidos os resultados mostrados na Figura 31. 
DPPC

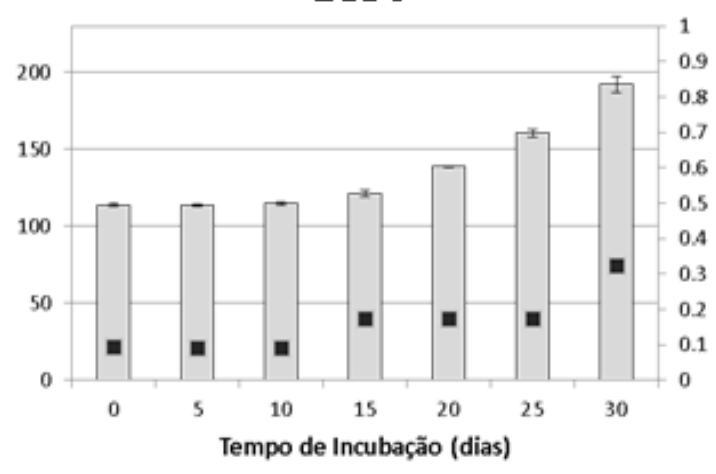

DPPC:LA 80:20

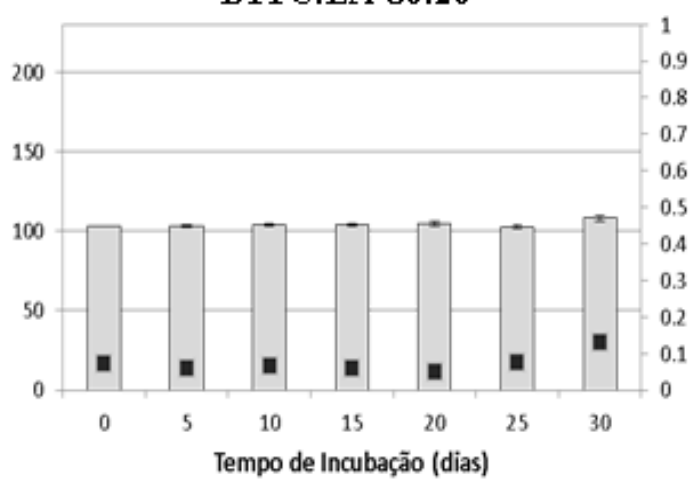

DPPC:LA 60:40

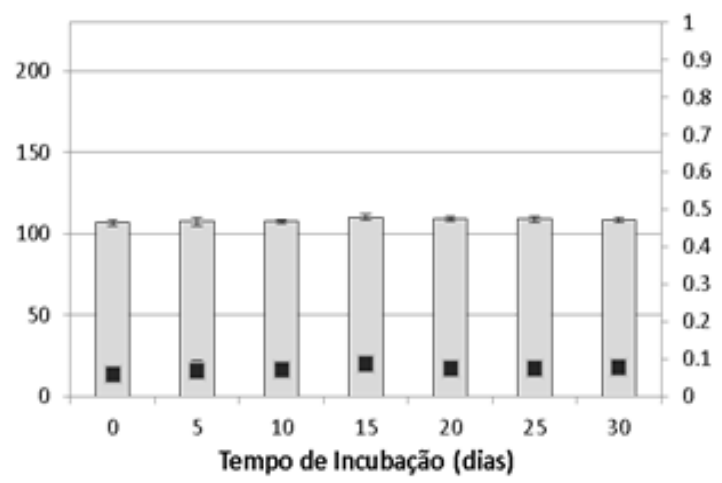

DPPC:LA 90:10

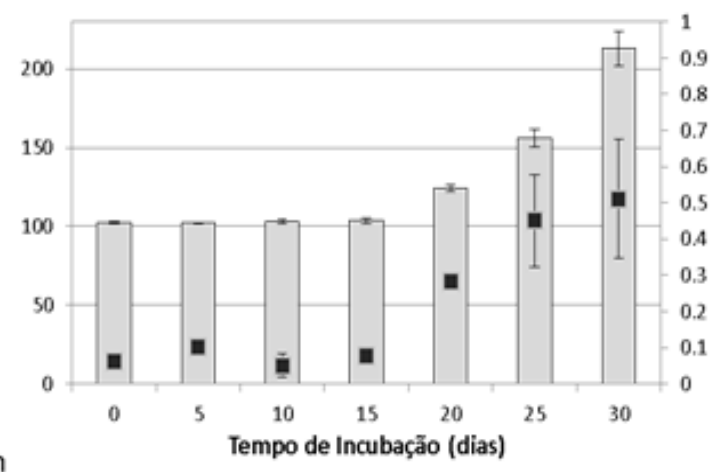

DPPC:LA 70:30

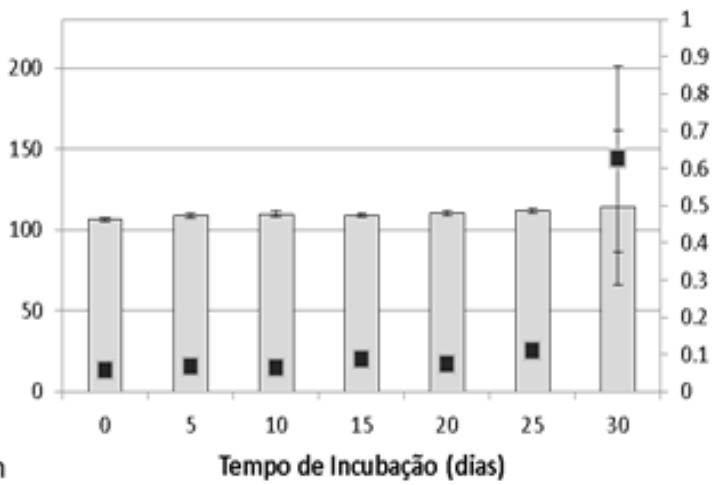

DPPC:LA 50:50

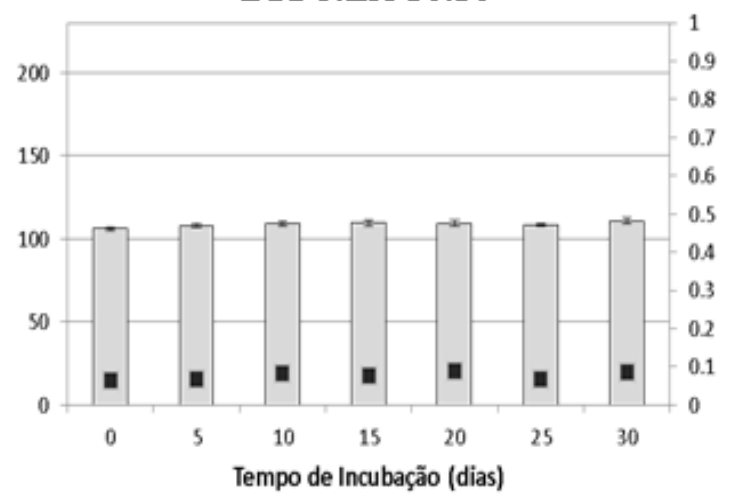

Figura 31- Variação nos valores de Dh e PdI em função do tempo para LUV diferentes concentrações de LA em tampão borato $10 \mathrm{mM}, \mathrm{pH} 9,0$.

Os resultados obtidos em pH 9,0 mostram que a presença do LA nas LUV favoreceu sua estabilidade física. No período avaliado, as formulações com concentrações a partir de $20 \%$ de LA mantiveram seu tamanho próximo àquele do dia inicial da medida e a polidispersidade se manteve abaixo de 0,2 após um mês. As amostras com LA apresentaram melhores resultados do que os obtidos para a amostra contendo apenas DPPC, que teve aumento no Dh e no PdI principalmente após o $15^{\circ}$ dia de incubação.

Os resultados mostrados na Figura 31 estão de acordo com trabalhos descritos na literatura que mostram que a presença de carga na membrana favorece sua estabilidade física, 
uma vez que evita fusão e agregação devido às interações eletrostáticas. Por isso as amostras com maiores concentrações de LA se mostraram mais estáveis nesta condição de pH. O pKa do ácido láurico em água é $\approx 5,3$ e seu pKa aparente na membrana é $\approx 7,5$ (MORROW; KOENIG; SHEN, 2012). Em pH 9,0 a maior parte das moléculas de LA encontram-se desprotonadas, com carga negativa, o que leva à maior estabilização das partículas.

Na Figura 32 estão os resultados de Dh e PdI obtidos em pH 7,4 em função do tempo.
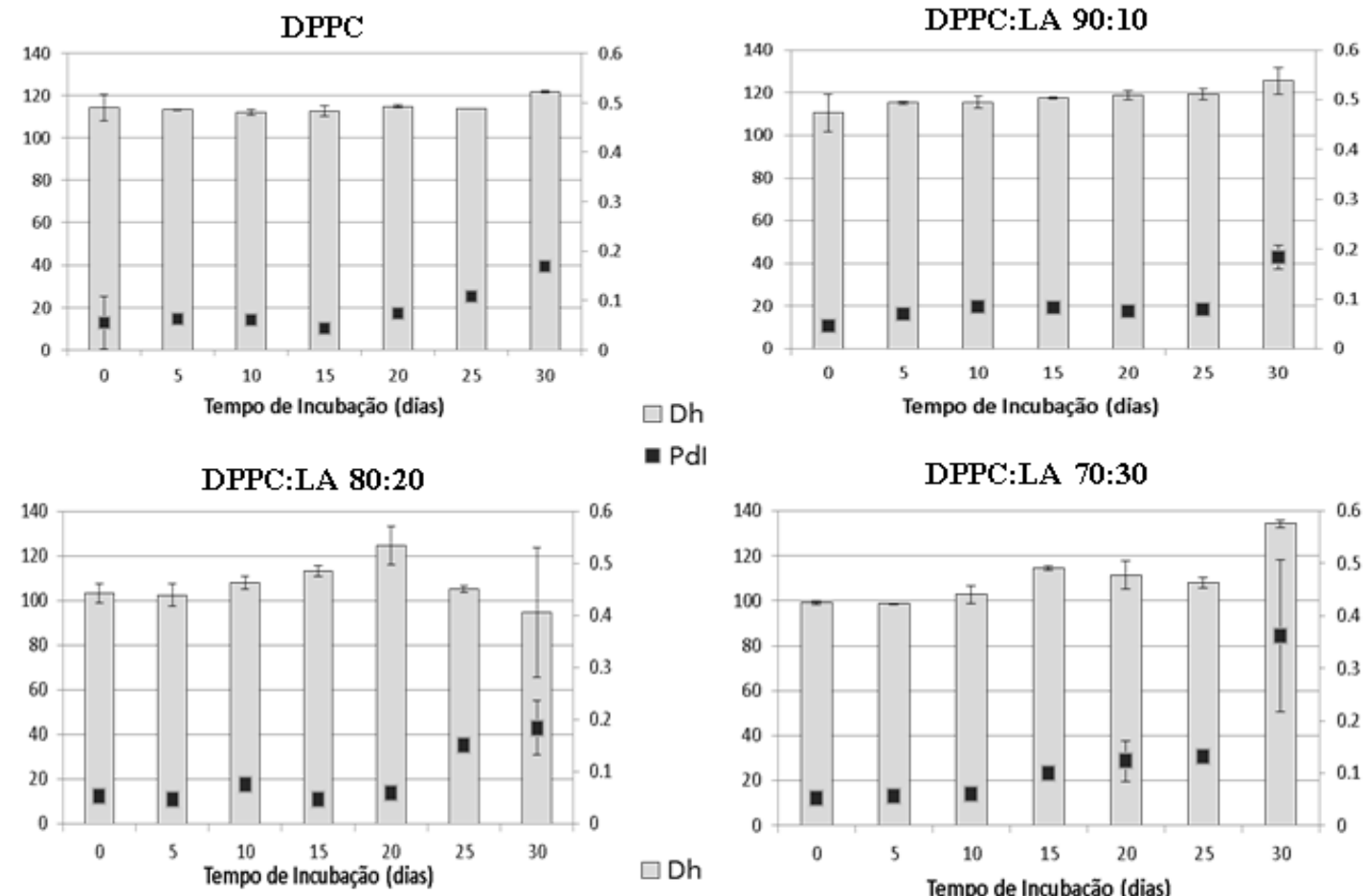

adl
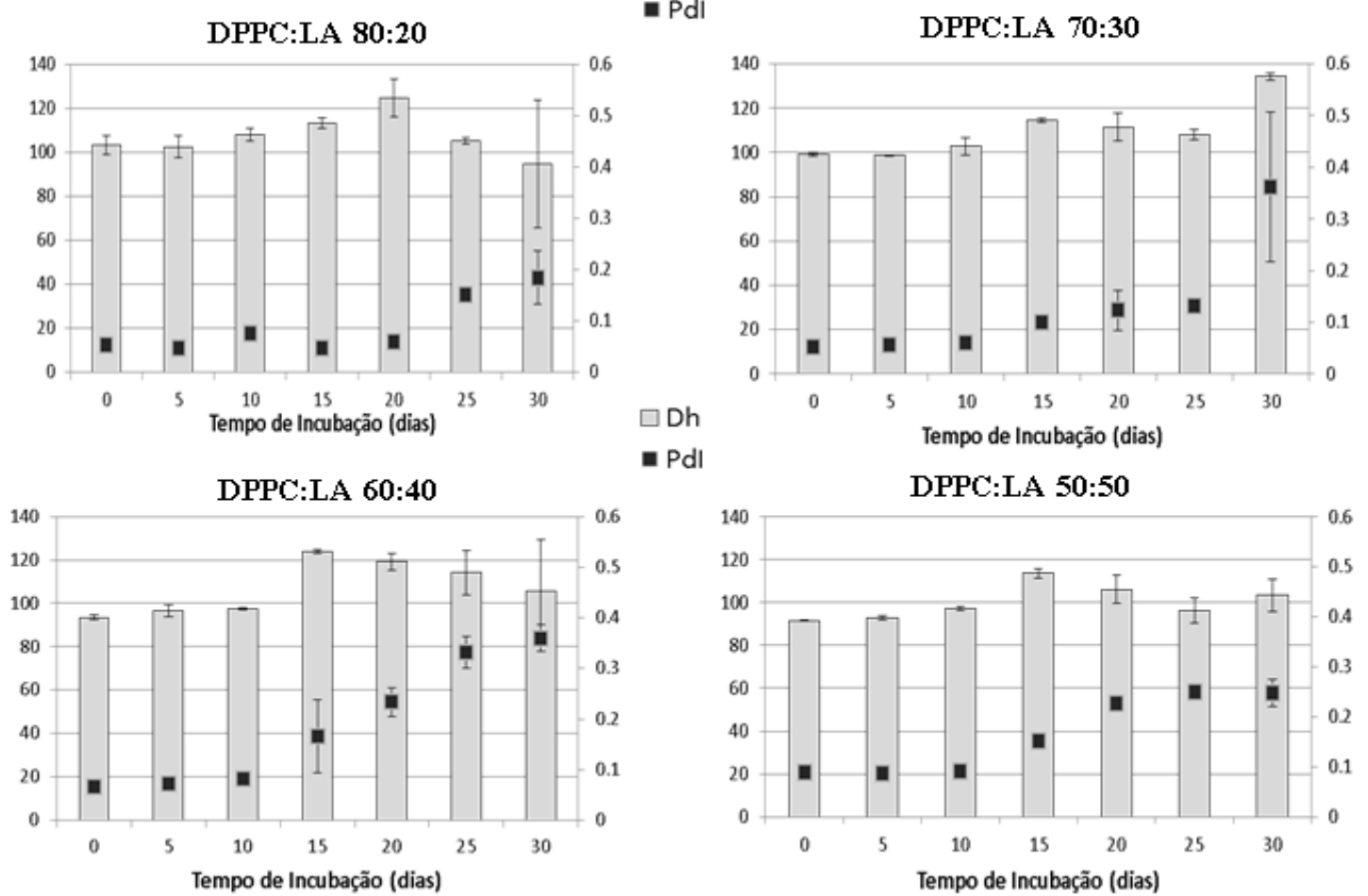

Figura 32- Variação nos valores de Dh e PdI ao em função do tempo para LUV com diferentes concentrações de LA em tampão tris-HCl $10 \mathrm{mM} \mathrm{pH} \mathrm{7,4.}$

Em pH 7,4 também se observa uma diminuição do diâmetro das LUV em função do aumento da \% LA. Em pH 7,4, que é próximo ao pKa aparente do LA na membrana, ainda há moléculas carregadas negativamente nas vesículas, o que também favorece sua estabilidade em relação a manutenção do Dh. Diferentemente dos resultados apresentados para o pH 9,0, 
houve um aumento mais acentuado dos valores de PdI, que atingiu valores superiores a 0,2 para as amostras com concentração igual ou maior a 30\% de LA.

Outro fator que deve ser levado em consideração para se explicar a diminuição do Dh com o aumento de LA é que a área da cabeça do LA é menor que a do DPPC e que o LA possui apenas uma cadeia alquílica com número de carbonos menor que o do ácido palmítico do DPPC. Assim, um aumento na concentração de LA pode resultar em LUV de menor diâmetro como observado na Figura 32.

Para verificar o efeito da protonação do LA no Dh e PdI preparamos as LUV em pH 5,0 e determinamos esses parâmetros em função do tempo (Figura 34). A Figura 33 mostra os valores de Dh encontrados para as amostras com diferentes concentrações de LA em pH 5,0, medidas no dia de preparo das amostras.

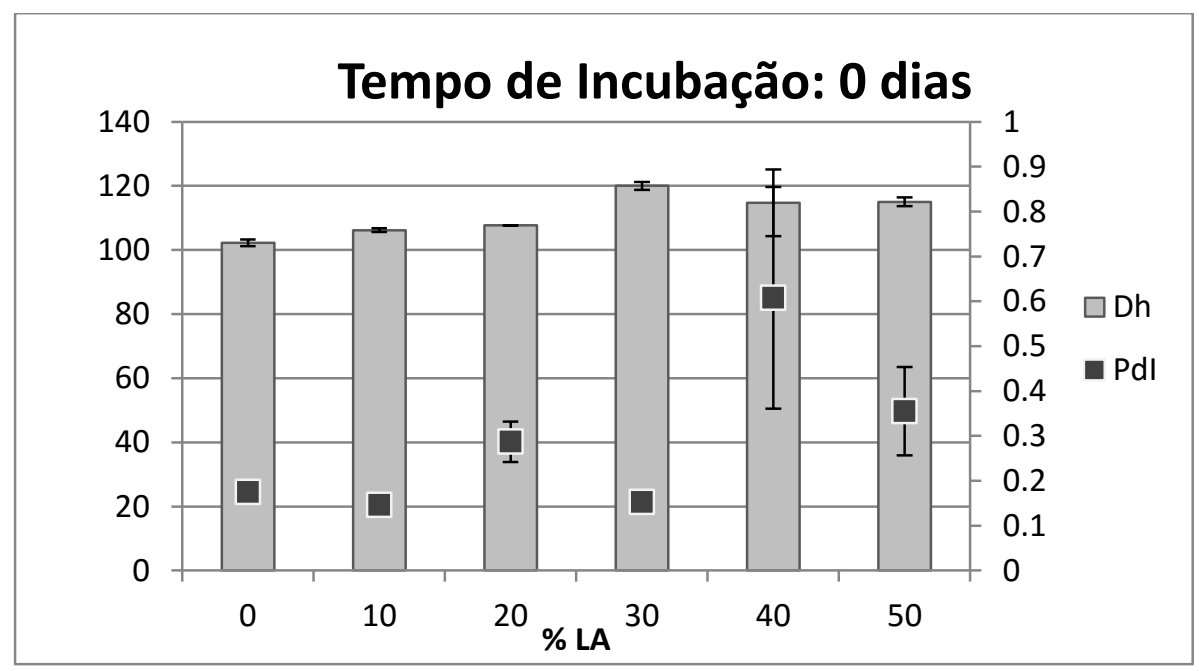

Figura 33- Valores de Dh e PdI para LUV com diferentes \%de LA em tampão acetato 10 mM, pH 5,0.

$\mathrm{O} \mathrm{pH}$ da pele do rosto varia entre 4,5 e 6,0, dependendo do tipo de pele (PURDY; DE BERKER, 2011). Esse pH é próximo do pKa do LA em água. Neste $\mathrm{pH}$ a maioria das moléculas de LA na bicamada se encontram protonadas, com carga zero; isso favorece ainda mais a sua partição nas vesículas e aumenta sua interação com os fosfolipídios componentes da membrana.

Na Figura 33 observamos que não há diminuição do Dh com o aumento da \%LA, como mostrado anteriormente para o $\mathrm{pH}$ 7,4 no dia em que as amostras foram preparadas (tempo de incubação 0). Além disso, foi possível confirmar que no dia inicial do ensaio todas as amostras em pH 5,0 apresentaram Dh próximo a $100 \mathrm{~nm}$. 


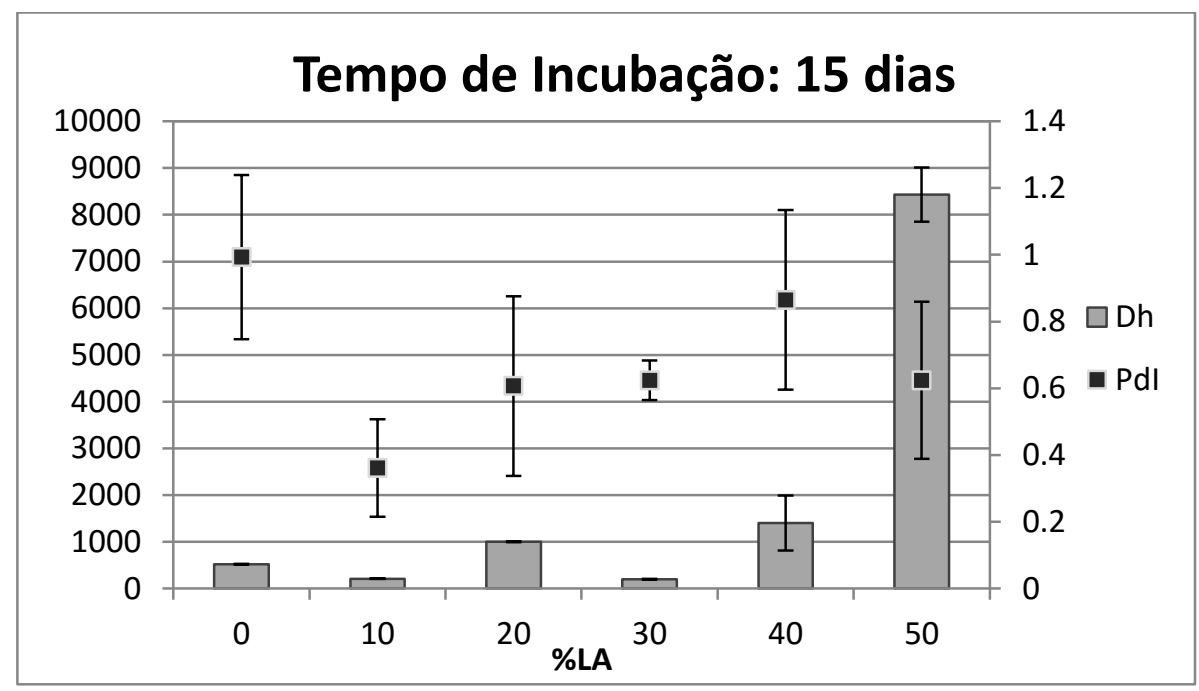

Figura 34- Efeito do tempo de incubação nos valores de Dh e PdI para LUV com diferentes concentrações de LA em tampão acetato $10 \mathrm{mM} \mathrm{pH} \mathrm{5,0.}$

Como se pode observar nos dados da Figura 34, em pH 5,0 a estabilidade física das LUV foi bastante diferente dos resultados obtidos em $\mathrm{pHs}$ maiores. As vesículas não se mantiveram estáveis com relação ao tamanho durante todo o período de 30 dias e o aumento da concentração de LA, [LA], levou a um aumento mais pronunciado do Dh em função do tempo do que nos pHs mais altos. As amostras com [LA] a partir de 40\% se mostraram instáveis, com altos valores de Dh e PdI logo após uma semana de incubação. Em pH 5,0 só foi possível acompanhar a estabilidade física das amostras por 15 dias, pois a partir deste dia todas as amostras já apresentavam precipitados depositados no fundo dos tubos de ensaio (Figura 37a).

As medidas de Dh para as amostras de LUV com LA em pH 3,0 no dia inicial estão na Figura 35. O efeito de tempo de incubação no Dh e PDI das LUV preparadas em pH 3,0 estão na Figura 36. 


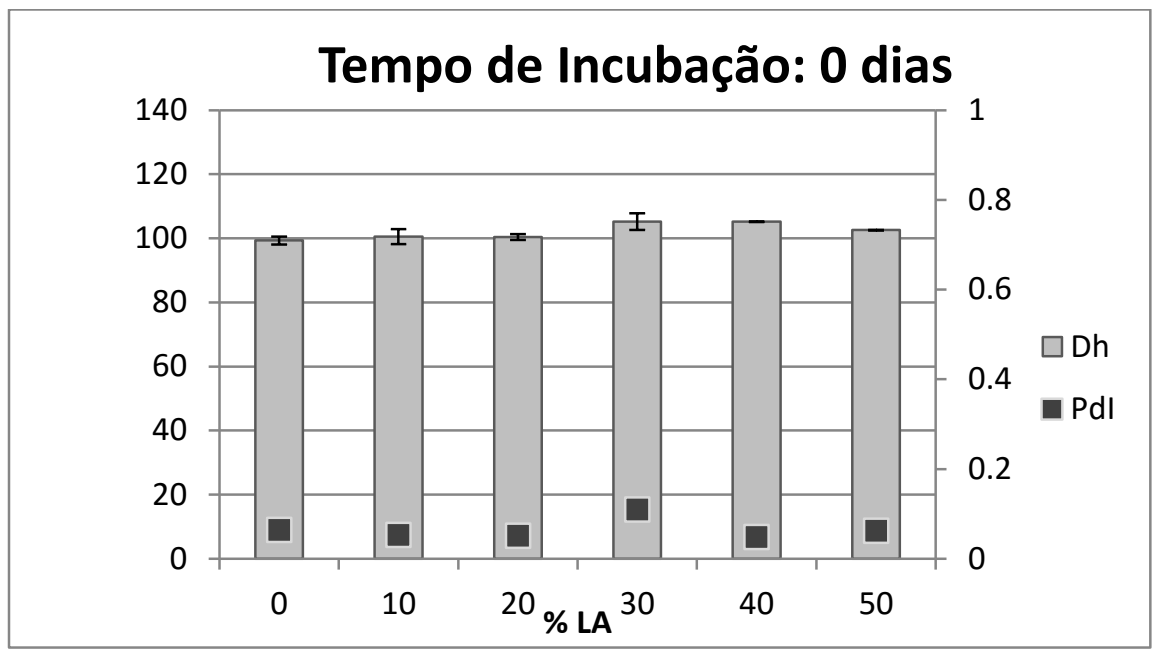

Figura 35- Valores de Dh e PdI para LUV com diferentes \% de LA em tampão formiato 10 mM, pH 3,0

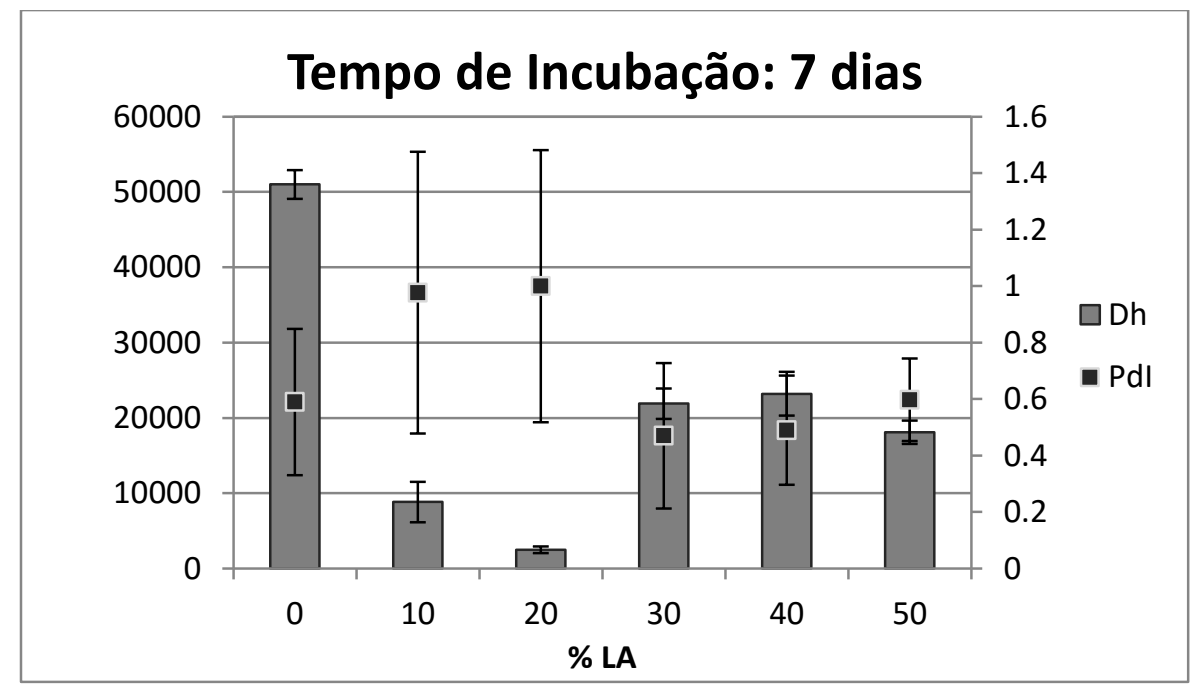

Figura 36- Efeito do tempo de incubação nos valores de Dh e PdI para LUV com diferentes concentrações de LA em tampão formiato $10 \mathrm{mM}, \mathrm{pH} 3,0$.

No dia inicial da medida todas as amostras de vesículas em pH 3,0 possuíam tamanho próximo a $100 \mathrm{~nm}$ e PdI abaixo de 0,2. Após 7 dias todas as amostras apresentaram Dh e PdI bem maiores que os determinados logo após o preparo das amostras (Figura 36).

Em pH 3,0 observamos que as amostras apresentaram uma instabilidade ainda maior do que em $\mathrm{pH} 5,0$, sendo possível realizar as medidas apenas por uma semana quando algumas amostras apresentaram precipitados (Figura 37b). 
(a)

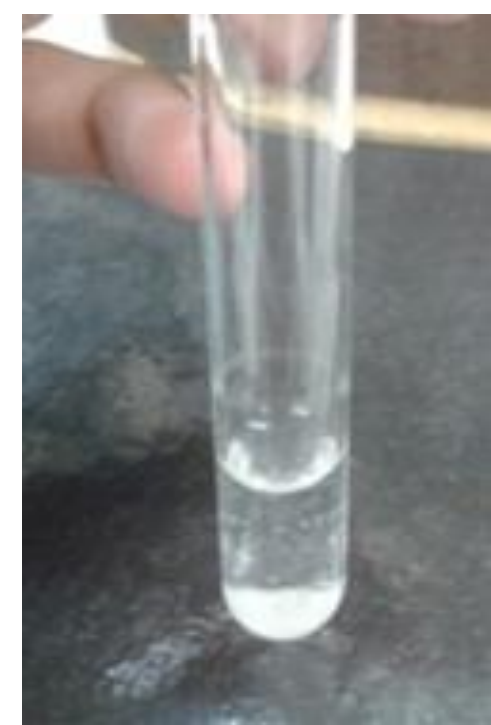

(b)

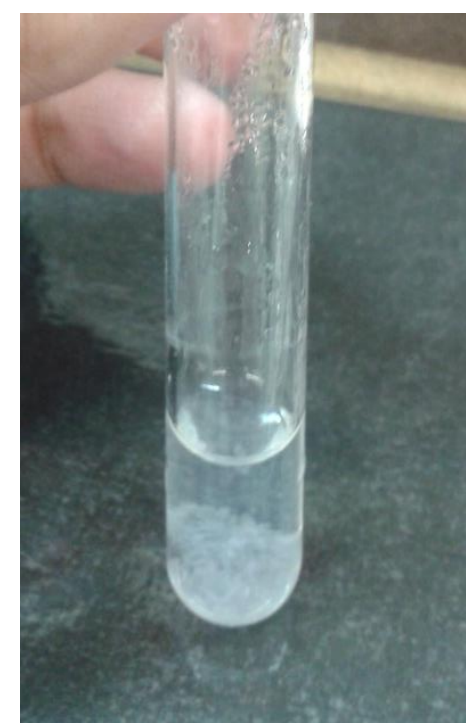

Figura 37- Amostra de LUV com formação de precipitados em: a) Tampão acetato, $10 \mathrm{mM}, \mathrm{pH} 5,0$; b) Tampão formiato $10 \mathrm{mM}, \mathrm{pH} 3,0$.

Em pH 3,0 quase a totalidade das moléculas de LA encontram-se protonadas e sua interação com os fosfolipídios pode ocorrer através da formação de pontes de hidrogênio entre o grupo carboxílico protonado e o fosfato das cabeças do DPPC. Em pH 3 ocorre também a protonação do grupo fosfato do fosfolipídio, cujo pKa é 2,86. Ocorre, portanto, uma diminuição das cargas na interface da bicamada devido ao aumento de LA e consequentemente diminuição da \% de DPPC nas LUV. Isto dificulta a interação com a água na interface das bicamadas o que explica a diminuição da estabilidade.

\subsection{CALORIMETRIA DIFERENCIAL DE VARREDURA}

A presença de LA na bicamada das LUV pode alterar sua fluidez dificultando ou facilitando a sua passagem da fase gel para a fase líquido-cristalina. A calorimetria diferencial de varredura permitiu verificar alterações que o LA causa nos parâmetros de transição de fase das vesículas de DPPC.

Na Figura 38 apresentamos os gráficos de $\mathrm{Cp}\left(\mathrm{kcal} / \mathrm{mol} /{ }^{0} \mathrm{C}\right)$ vs temperatura $\left({ }^{0} \mathrm{C}\right)$ de LUV variando-se a \% de LA nas vesículas de DPPC. Observa-se com o aumento de temperatura ocorre uma variação de $\mathrm{Cp}$ e, em uma temperatura especifica, observa-se um máximo de em Cp para cada preparação de LUV. A temperatura aonde ocorre o máximo de $\mathrm{Cp}$ corresponde a temperatura de transição de fase. A largura a meia altura do pico da transição corresponde a cooperatividade do processo. 

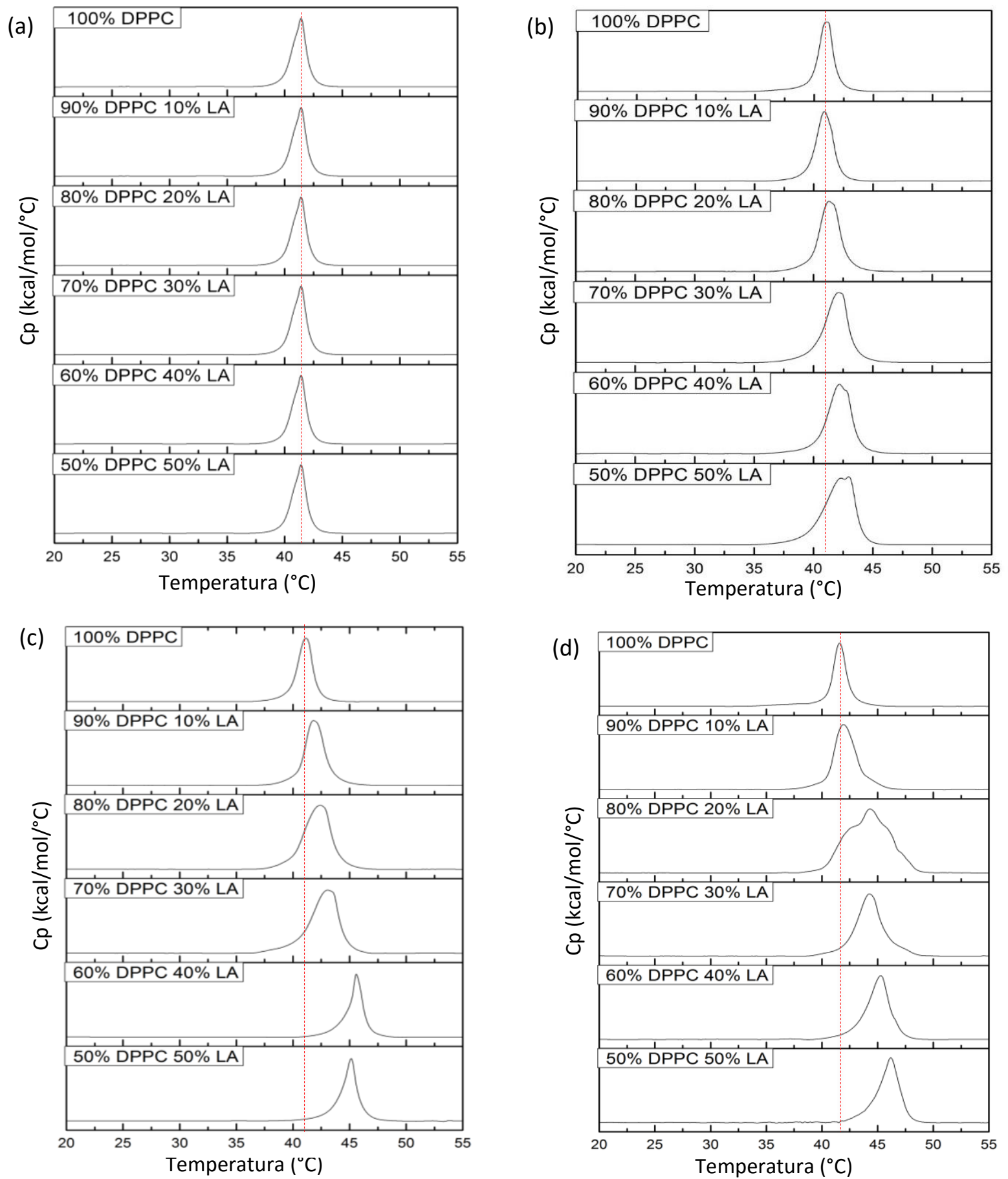

Figura 38- Termogramas das LUV de DPPC/LA nos tampões (a)borato $10 \mathrm{mM} \mathrm{pH} \mathrm{9,0,} \mathrm{(b)} \mathrm{tris-HCl}$ $10 \mathrm{mM} \mathrm{pH} \mathrm{7,4,} \mathrm{(c)} \mathrm{acetato} 10 \mathrm{mM} \mathrm{pH} \mathrm{5,0} \mathrm{e} \mathrm{(d)} \mathrm{formiato} 10 \mathrm{mM} \mathrm{pH} \mathrm{3,0.}$

Na Figura 38 observamos que LUV de DPPC não apresentaram pré-transição. Isso acontece pelo fato das análises terem sido realizadas com LUV. Ao utilizarmos MLV aparece a pre-transição (resultado não mostrado), uma melhor definição dos picos devido à presença de mais lamelas nos lipossomas e, consequentemente, maior cooperatividade (MARIA; ALVES; COIMBRA, 2013). Na Figura 39 mostra-se o gráfico de Tm vs \%LA para LUV de 
DPPC:LA em todos os pHs. Como se pode observar, para o DPPC sem LA a variação de Tm é muito pequena, variando de 41 até 41,6 quando o $\mathrm{pH}$ varia entre 9,0 e 3,0.

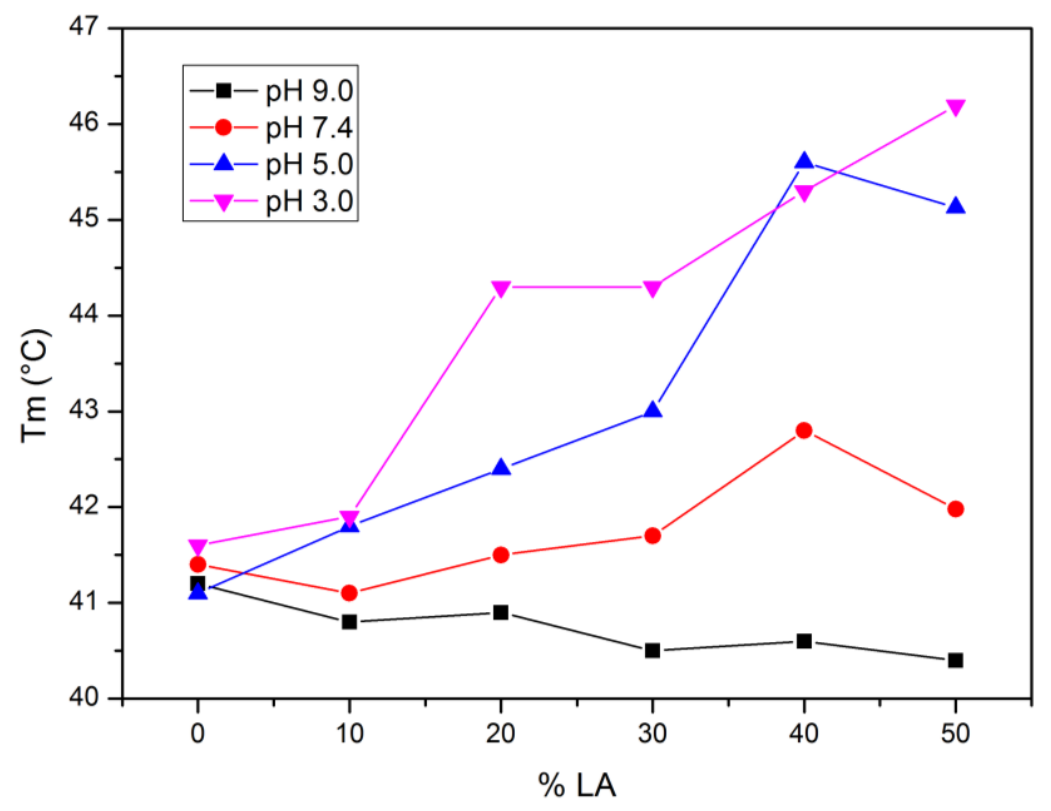

Figura 39- Valores de Tm de LUV de DPPC:LA obtidos para cada concentração de LA em diferentes pHs.

Na Tabela 1 estão os valores para a cooperatividade $\left(\Delta^{1} / 2\right)$ obtidos para todas as LUV com e sem [LA] nas quatro condições de pH estudadas.

Tabela 1- Valores da cooperatividade para as LUV de DPPC:LA nos pHs 9,0, 7,4, 5,0 e 3,0.

\begin{tabular}{ccccc}
\hline Amostra & $\Delta^{\mathbf{1} / \mathbf{2}} \mathbf{p H} \mathbf{9 , 0}$ & $\Delta^{\mathbf{1} / \mathbf{2}} \mathbf{p H} \mathbf{7 , 4}$ & $\Delta^{\mathbf{1} / \mathbf{2}} \mathbf{p H} \mathbf{5 , 0}$ & $\Delta^{\mathbf{1} / \mathbf{2}} \mathbf{p H ~ 3 , 0}$ \\
\hline DPPC & 1.37 & 1.35 & 1.49 & 1.30 \\
DPPC:LA 90:10 & 1.34 & 1.53 & 1.89 & 2.16 \\
DPPC:LA 80:20 & 1.40 & 1.80 & 2.65 & 4.81 \\
DPPC:LA 70:30 & 1.38 & 2.43 & 2.65 & 2.38 \\
DPPC:LA 60:40 & 1.42 & 2.13 & 1.18 & 2.11 \\
DPPC:LA 50:50 & 1.43 & 1.85 & 1.35 & 2.01 \\
\hline
\end{tabular}

Para as LUV em pH 9,0 verificamos que a Tm das misturas de DPPC/LA diminuiu quando comparada com a do DPPC sem LA e a variação é maior quanto maior é a \% de LA na mistura (Figura 39). Em pH 9,0 a concentração de íons laurato é maior do que de ácido láurico protonado. Os íons laurato incorporados nas LUV criam um ambiente com cargas negativas próximo das cabeças polares, favorecendo interações eletrostáticas repulsivas nesta 
região. A entalpia envolvida no processo de transição de fase depende das interações envolvidas entre as cadeias hidrofóbicas e entre as cabeças polares (BARROSO, 2011). Uma pequena diminuição da Tm pode estar relacionada às forças repulsivas ocasionadas pela presença de LA, que também aumentam a hidratação da região das cabeças polares das LUV, facilitando sua passagem para a fase líquida cristalina. Por outro lado, a partição do LA na forma negativa deve ser menor em $\mathrm{pH}$ 9,0 do que em pHs menores já que o laurato é muito mais solúvel em água do que o ácido láurico e talvez por isso a diminuição de Tm é pequena. A cooperatividade da transição praticamente não mudou em pH 9,0 (Tabela 1) e os picos apresentaram larguras parecidas.

Em pH 7,4 observamos um aumento da Tm em mais de $1{ }^{\circ} \mathrm{C}$ para a amostra com $40 \%$ de LA quando comparada a Tm do DPPC (Figura 39). As amostras com 40 e 50\% de LA apresentaram uma divisão no pico da transição de fase principal, indicando o início de uma separação de fase com domínios lipídicos mais ricos e outros possivelmente mais pobres em LA. Além disso, com a presença do LA os picos se tornaram mais largos, indicando uma diminuição da cooperatividade, que também é observada pelos valores da Tabela 1.

Para as LUV preparadas em $\mathrm{pH}$ 5,0 observou-se um aumento de Tm em função do aumento da $\%$ de LA. Nas amostras com $50 \%$ de LA houve um aumento de cerca de $4{ }^{0} \mathrm{C}$ na Tm em comparação com as LUV de DPPC e uma diminuição da cooperatividade, maior do que a observada em pH 7,4. Em pH 5,0 a largura a meia altura dos picos aumenta até a amostra contendo $30 \%$ de LA e em maiores concentrações de LA o perfil dos picos volta a ser semelhante ao do DPPC (Figura 38, Tabela 1), sendo aparentemente uma amostra mais homogênea, com uma transição de fase de primeira ordem.

Em pH 3,0 observa-se também que Tm aumenta com a \% LA chegando-se a uma variação de $5{ }^{\circ} \mathrm{C}$ nas amostras com $50 \%$ de LA, quando comparadas com amostras de DPPC (Figura 39). Até as amostras com $20 \%$ de LA observou-se um pico bastante alargado e com diferentes regiões. Acima de $20 \%$ de LA a mistura se torna mais homogênea e o perfil dos termogramas fica mais estreito ("sharp").

Conforme o $\mathrm{pH}$ vai diminuindo, aumenta a concentração de LA protonado, o que favorece a sua partição nas bicamadas e interação com as moléculas de DPPC. Desta forma, faz-se necessária uma maior energia para que as membranas passem para uma fase mais fluida. Isso indica que nestas condições de $\mathrm{pH}$ a transição da fase gel para a fase líquido cristalina foi dificultada com a presença do LA e comprova que a carga do ácido láurico está bastante relacionada com seu efeito sobre as membranas e não apenas a sua cadeia alquilica. 
Por outro lado, a cooperatividade diminui. Isto pode ser devido à diminuição da interação entre as moléculas de DPPC devido à presença de do LA protonado que impede que as cadeias do DPPC se acomodem tão bem como na sua ausência.

\subsection{ESPALHAMENTO DE RAIOS-X A BAIXO ÂNGULO (SAXS)}

O SAXS representa uma das técnicas mais adequadas para estudos estruturais a nível atômico e molecular. No caso deste trabalho, a técnica foi empregada para uma avaliação criteriosa das modificações provocadas pela presença do ácido láurico junto às LUV em diferentes $\mathrm{pHs}$.

A seguir, nas Figuras 40 e 42 estão apresentados os dados obtidos apenas para o pH 7,4, a fim de servir como exemplo ilustrativo da análise, que foi realizada da mesma maneira para todos os pHs. Serão apresentados os dados tratados, para os quais foram feitas correções e calibrações necessárias comentadas anteriormente. Para uma melhor visualização gráfica, as curvas foram espaçadas vertical e logaritmicamente. Os dados foram ajustados usando-se o modelo de 4 gaussianas, descrito anteriormente, e em todos os casos nota-se que o ajuste é satisfatório, conseguindo descrever bem os dados experimentais.

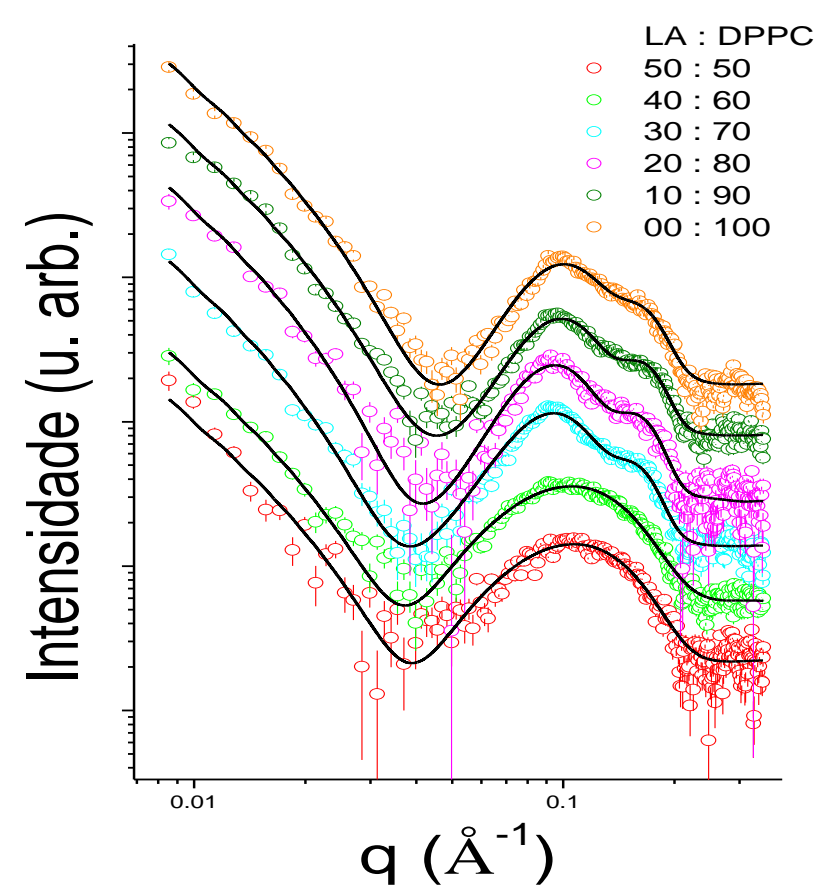

Figura 40- Dados experimentais de SAXS (círculos abertos) e ajuste com o modelo (linha cheia). Os ajustes são bastante satisfatórios em toda a região de q considerada. As LUV de DPPC:LA foram preparadas em tampão Tris-HCl, 10 mM, pH 7,4. A concentração das LUV era 10 mM. 
Com o perfil das curvas de espalhamento pode-se obter informações sobre a lamelaridade das vesículas, como mostrado abaixo na Figura 41.

A)

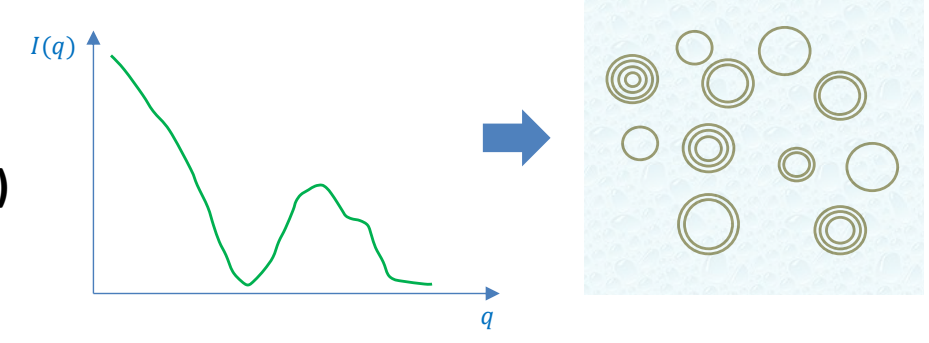

B)

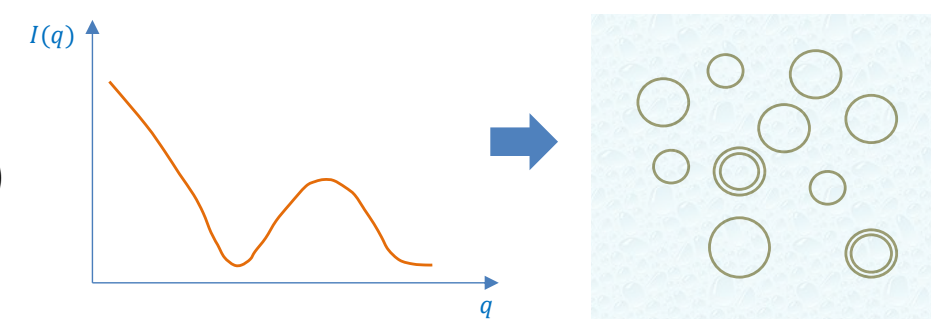

Figura 41- A curva experimental de SAXS mostrando vesículas A) multilamelares e B) unilamelares.

O perfil mostrado na Figura 41A é característico de uma amostra com MLV e o perfil da Figura 41B característico de amostra contendo predominantemente LUV.

Como comentado na seção "Materiais e Métodos", o fator de forma é calculado a partir da modelagem do perfil de contraste de densidade eletrônica da bicamada lipídica, $\Delta \rho(r)$. Portanto, uma das informações provenientes do ajuste é o perfil $\Delta \rho(r)$. Logo, seria possível, em princípio, detectar mudanças na bicamada devido à presença do ácido láurico, seja em contraste eletrônico, seja no aumento da espessura da bicamada.

Os perfis de contraste de densidade eletrônica usados para modelar o fator de forma $P(q)$ das bicamadas estão representados abaixo (FIGURA 42). 


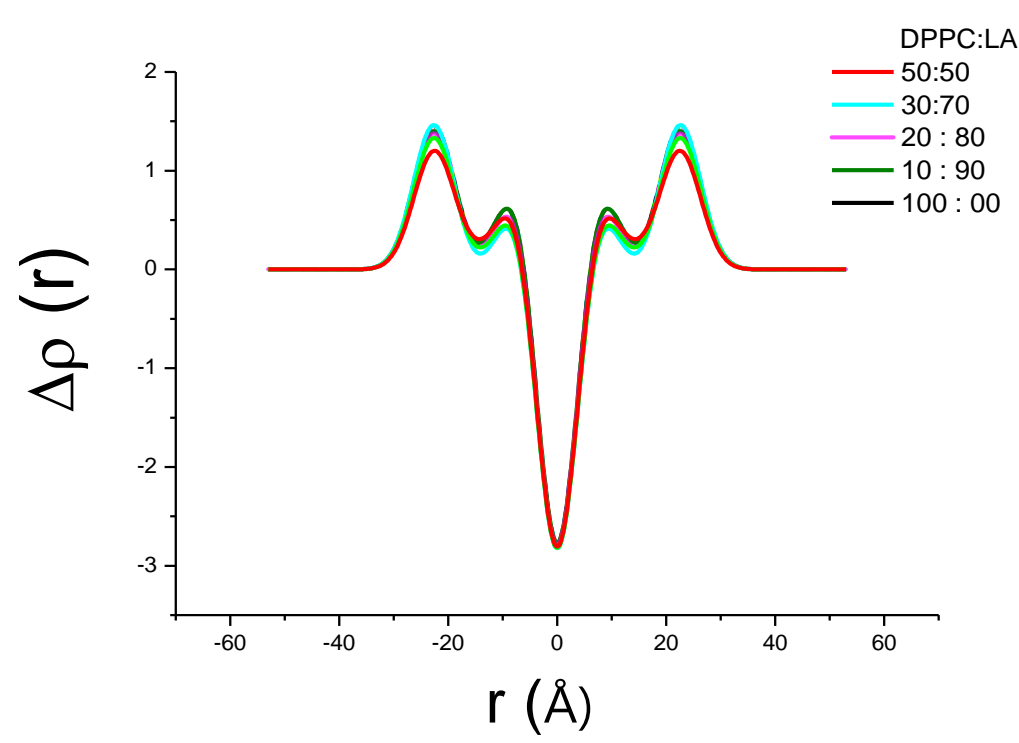

Figura 42- Perfil de contraste de densidade eletrônico da bicamada lipídica de LUV em pH 7,4 contendo diferentes razões DPPC:LA obtido a partir do ajuste dos dados experimentais de SAXS.

No caso deste trabalho foi possível constatar mudanças principalmente no contraste eletrônico no que se refere à região correspondente às cabeças polares (Figura 42) em todas as condições de $\mathrm{pH}$ na presença do LA, mesmo nas menores concentrações. Portanto, o ácido láurico interage predominantemente com as cabeças polares do lipídeo.

Através dos parâmetros determinados no ajuste das curvas experimentais foram obtidos os parâmetros que descrevem a flexibilidade e a estrutura das bicamadas. Na Tabela 2, estão representados os valores para a espessura da bicamada lipídica, $\delta(\AA)$, a periodicidade lamelar, D $(\AA ̊)$, o parâmetro de Caillé ( $\eta)$ e o número de bicamadas correlatas $(\mathrm{N})$.

É importante ressaltar que para as amostras com $\mathrm{N}=1$ (amostras com vesículas predominantemente unilamelares) não se aplicam valores para a periodicidade lamelar e para o parâmetro de Caillè, pois eles não apresentam estrutura e por isso não estão representados na Tabela 2. 
Tabela 2- Valores dos parâmetros do modelo obtido a partir do ajuste dos dados experimentais de SAXS.

\begin{tabular}{|c|c|c|c|c|c|c|c|c|c|c|c|c|}
\hline \multicolumn{13}{|c|}{ Parâmetro $\delta(\AA)$} \\
\hline Razão LA: DPPC & \multicolumn{3}{|c|}{$\mathrm{pH} 3,0$} & \multicolumn{3}{|c|}{$\mathrm{pH} 5,0$} & \multicolumn{3}{|c|}{$\mathrm{pH} 7,4$} & \multicolumn{3}{|c|}{$\mathrm{pH} 9,0$} \\
\hline 1.0 & 51.0 & \pm & 1.2 & 50.7 & \pm & 5.9 & 51.3 & \pm & 5.1 & 52.0 & \pm & 2.9 \\
\hline 0.7 & 50.5 & \pm & 1.1 & 52.0 & \pm & 1.9 & 50.9 & \pm & 0.7 & 51.2 & \pm & 2.9 \\
\hline 0.4 & 52.1 & \pm & 1.4 & 51.4 & \pm & 6.9 & 50.8 & \pm & 3.7 & 52.1 & \pm & 6.9 \\
\hline 0.3 & 51.9 & \pm & 3.2 & 52.5 & \pm & 9.2 & 52.6 & \pm & 2.7 & 52.1 & \pm & 2.2 \\
\hline 0.1 & 51.7 & \pm & 2.9 & 50.8 & \pm & 5.1 & 52.0 & \pm & 6.9 & 50.9 & \pm & 6.4 \\
\hline 0.0 & 50.8 & \pm & 2.6 & 51.2 & \pm & 4.9 & 52.1 & \pm & 3.2 & 50.7 & \pm & 3.2 \\
\hline \multicolumn{13}{|c|}{ Parâmetro $\mathbf{D}(\AA)$} \\
\hline Razão LA: DPPC & \multicolumn{3}{|c|}{$\mathrm{pH} 3,0$} & \multicolumn{3}{|c|}{$\mathrm{pH} 5,0$} & \multicolumn{3}{|c|}{$\mathrm{pH} 7,4$} & \multicolumn{3}{|c|}{$\mathrm{pH} 9,0$} \\
\hline 1.0 & 69.2 & \pm & 2.4 & \multicolumn{3}{|c|}{ NA } & 74.0 & \pm & 7.1 & \multicolumn{3}{|c|}{ NA } \\
\hline 0.7 & 70.0 & \pm & 3.2 & 71.0 & \pm & 0.9 & 72.0 & \pm & 4.3 & \multicolumn{3}{|c|}{ NA } \\
\hline 0.4 & 73,0 & \pm & 5.4 & 69.9 & \pm & 9.1 & \multicolumn{3}{|c|}{ NA } & \multicolumn{3}{|c|}{ NA } \\
\hline 0.3 & 68.7 & \pm & 2.3 & 70.3 & \pm & 0.2 & \multicolumn{3}{|c|}{ NA } & \multicolumn{3}{|c|}{ NA } \\
\hline 0.1 & \multicolumn{3}{|c|}{ NA } & 68.9 & \pm & 1.1 & 73.6 & \pm & 7.1 & \multicolumn{3}{|c|}{ NA } \\
\hline 0.0 & \multicolumn{3}{|c|}{ NA } & 68.0 & \pm & 9.1 & 67.7 & \pm & 7.8 & 66.6 & \pm & 1.9 \\
\hline \multicolumn{13}{|c|}{ Parâmetro $\eta$} \\
\hline Razão LA: DPPC & \multicolumn{3}{|c|}{$\mathrm{pH} 3,0$} & \multicolumn{3}{|c|}{$\mathrm{pH} 5,0$} & & $\mathrm{OH7}$ & & \multicolumn{3}{|c|}{$\mathrm{pH} 9,0$} \\
\hline 1.0 & 0.60 & \pm & 0.05 & \multicolumn{3}{|c|}{ NA } & 0.60 & \pm & 0.10 & \multicolumn{3}{|c|}{ NA } \\
\hline 0.7 & 0.40 & \pm & 0.11 & 0.22 & \pm & 0.04 & 0.50 & \pm & 0.10 & & NA & \\
\hline 0.4 & 0.30 & \pm & 0.05 & 0.23 & \pm & 0.03 & & NA & & & NA & \\
\hline 0.3 & 0.12 & \pm & 0.05 & 0.26 & \pm & 0.10 & & NA & & & NA & \\
\hline 0.1 & & NA & & 0.02 & \pm & 0.01 & 0.02 & \pm & 0.01 & & NA & \\
\hline 0.0 & & NA & & 0.04 & \pm & 0.05 & 0.08 & \pm & 0.02 & 0.04 & \pm & 0.03 \\
\hline & & & & Parâ & netr & & & & & & & \\
\hline Razão LA: DPPC & & $\mathrm{pH} 3$, & & & H5, & & & H7, & & & $\mathrm{OH} 9, \mathrm{C}$ & \\
\hline 1.0 & 1.3 & \pm & 0.1 & 1.0 & \pm & 0.1 & 1.1 & \pm & 0.1 & 1.0 & \pm & 0.1 \\
\hline 0.7 & 1.8 & \pm & 0.1 & 1.3 & \pm & 0.1 & 2.0 & \pm & 0.2 & 1.0 & \pm & 0.1 \\
\hline 0.4 & 1.5 & \pm & 0.2 & 2.1 & \pm & 0.2 & 1.0 & \pm & 0.1 & 1.0 & \pm & 0.1 \\
\hline 0.3 & 1.1 & \pm & 0.1 & 2.4 & \pm & 0.1 & 1.0 & \pm & 0.1 & 1.0 & \pm & 0.1 \\
\hline 0.1 & 1.0 & \pm & 0.1 & 1.3 & \pm & 0.1 & 1.1 & \pm & 0.1 & 1.0 & \pm & 0.1 \\
\hline 0.0 & 1.0 & \pm & 0.1 & 1.3 & \pm & 0.1 & 1.3 & \pm & 0.2 & 1.5 & \pm & 0.1 \\
\hline
\end{tabular}




\subsubsection{Espessura da Bicamada}

Como foi descrito na seção 3.5.1 o pico do perfil de densidade eletrônica descrito por uma função gaussiana representa a posição das cabeças polares e o centro corresponde ao meio da bicamada. Com a distância do centro da bicamada até o ponto correspondente a meia altura da gaussiana foram obtidos os valores da metade da espessura da bicamada para todas as preparações de LUV.

A partir da Tabela 2 construiu-se o gráfico do comportamento de $\delta(\AA)$ para as LUV em função da \% de LA.

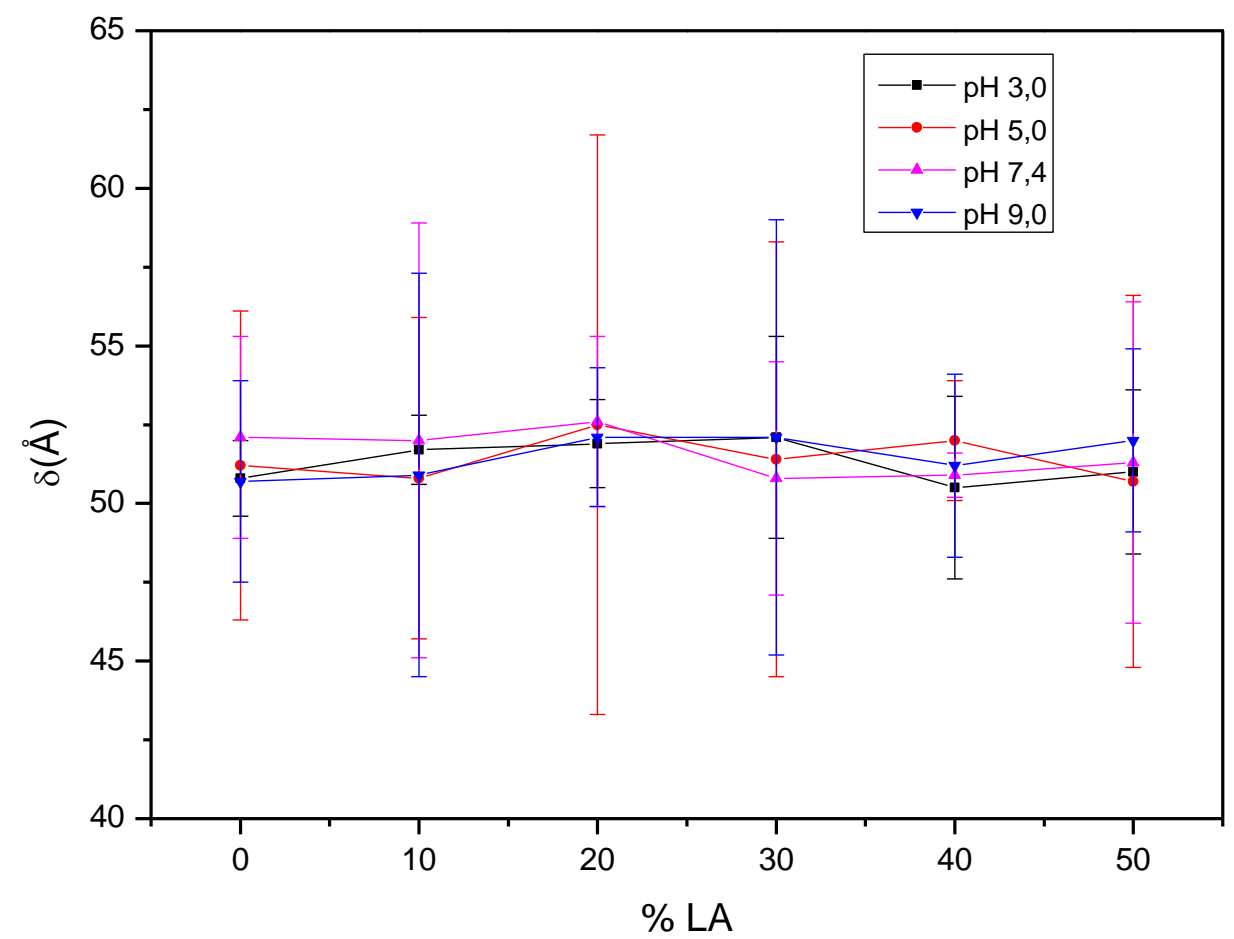

Figura 43- Comportamento da espessura da bicamada em função da \% de LA nas LUV em vários pHs; barras de erros com desvio padrão estão representadas verticalmente.

No que se refere à espessura $\delta$ da bicamada (Figura 43) é possível concluir que ela é praticamente constante em todos os casos (incluindo amostras constituídas apenas puramente por DPPC), e possui um valor médio da ordem de $\delta \cong 50 \AA$. Apesar da significativa barra de erros que aparece no gráfico indicando o desvio padrão, isso mostra que a variação no valor do $\mathrm{pH}$ e da concentração de LA não altera significativamente a espessura da bicamada. 


\subsubsection{Periodicidade Lamelar}

Na Figura 44 são apresentados os dados para o comportamento da periodicidade lamelar D (Å) em função da \% de LA. O comportamento de D é inversamente proporcional ao vetor de onda, sendo possível verificar como a periodicidade lamelar modifica I(q). A periodicidade lamelar pode ser determinada pela lei de Bragg através da equação $q_{1}=\frac{2 \pi}{D}$, onde $\mathrm{q}_{1}$ é o vetor de onda do pico de primeira ordem.

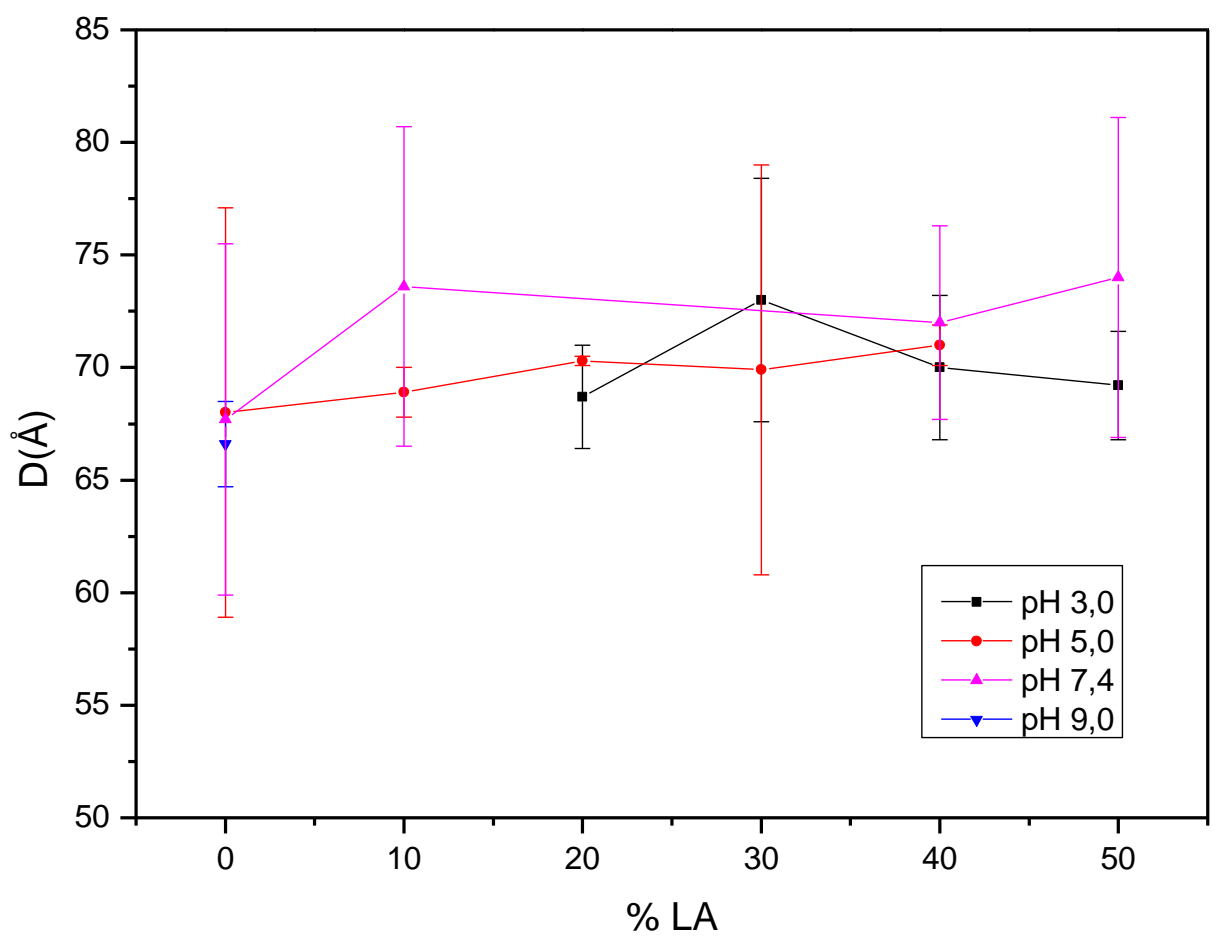

Figura 44- Comportamento da periodicidade lamelar em função da \% de LA das LUV; barras de erros com desvio padrão estão representadas verticalmente.

Na Figura 44 observamos que o parâmetro periodicidade lamelar $D$ também apresenta pouca alteração mesmo com a variação do $\mathrm{pH}$ e aumento da [LA] e varia em torno de $D \cong$ $70 \AA ̊$.

\subsubsection{Parâmetro de Caillè}

O parâmetro de Caillè relaciona as constantes elásticas que caracterizam a flexibilidade do sistema lamelar e pode ser descrito pela Equação 6: 


$$
\eta=\frac{q_{0}{ }^{2} k_{B} T}{8 \pi \sqrt{K \bar{B}}} \quad \text { (Equação 6) }
$$

onde $\mathrm{K}$ é o módulo de curvatura e $\bar{B}$ o modo de compressibilidade a potencial químico constante.

Alterações nas propriedades elásticas da fase lamelar são caracterizadas a partir do parâmetro de Caillè e da amplitude de flutuações das membranas. Quando a distância de separação entre as membranas diminui, o parâmetro de Caillè tende a decrescer, diminuindo a amplitude de flutuação das membranas (GERBELLI, 2012). Como $\eta$ é inversamente proporcional a $(\mathrm{K} \bar{B})$, sua diminuição corresponde ao aumento da rigidez da membrana.

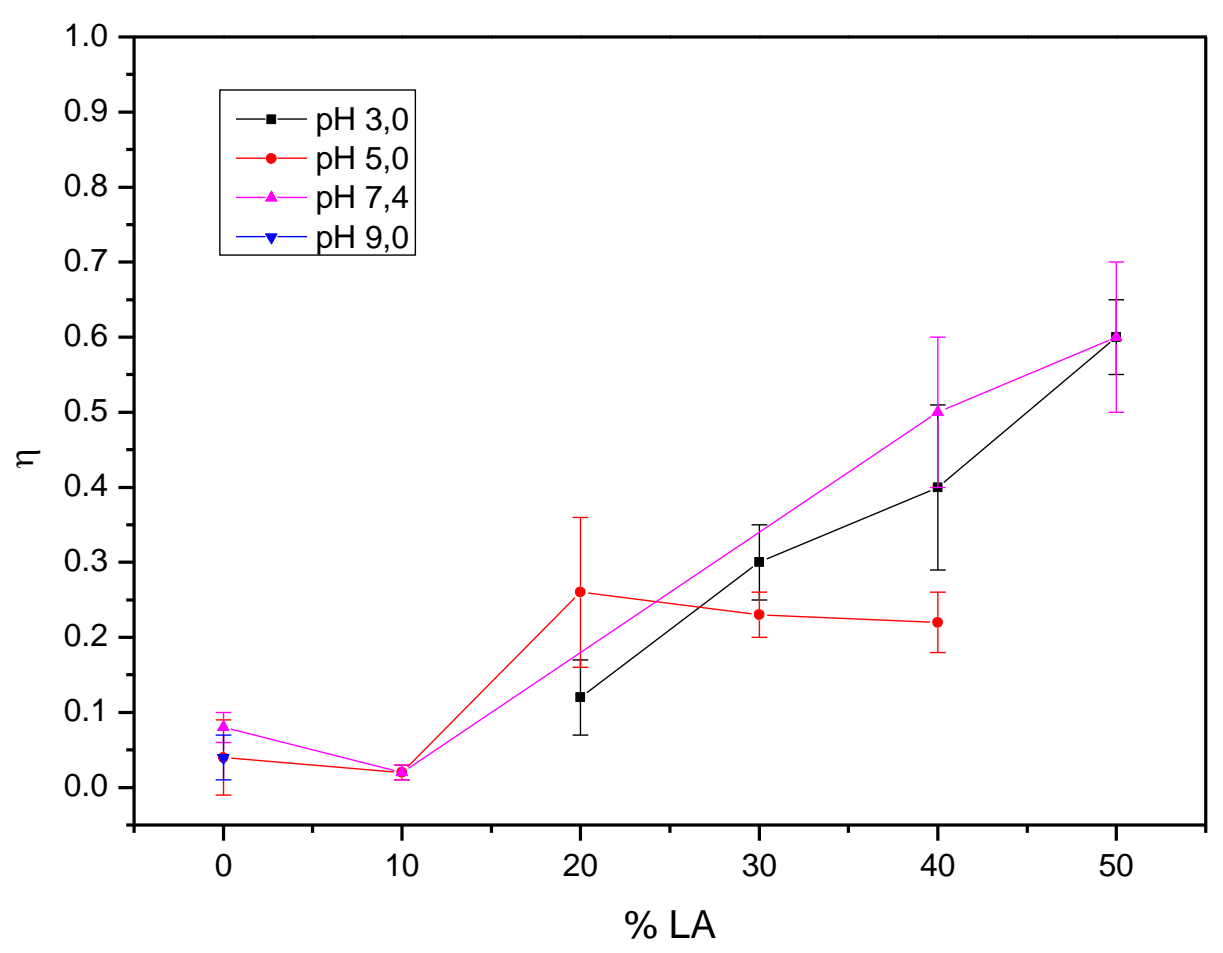

Figura 45- Comportamento do Parâmetro de Caillè em função da \% LA de LUV de DPPC:LA da amostra; barras de erros com desvio padrão estão representadas verticalmente.

Como podemos observar na Figura 45, o parâmetro de Caillè tende a aumentar conforme a \% de LA aumenta em todos os pHs. Isto significa que o LA deixa a membrana mais flexível independentemente de seu estado de protonação e carga. É importante ressaltar que este ensaio foi realizado a $25^{\circ} \mathrm{C}$, temperatura abaixo da Tm do DPPC. Sendo assim, abaixo da Tm, a presença do LA aumentou a flexibilidade das membranas. 


\subsubsection{Número Médio de Camadas Correlatas}

Nas curvas de SAXS para o pH 7,4, mostradas inicialmente na Figura 40, observamos que elas se diferenciaram principalmente pela forma do(s) pico(s) $\operatorname{largo(s)}$ entre $q \cong 0,04 \mathrm{e}$ $q \cong 0,2 \AA^{-1}$. Como comentado anteriormente, a forma desses picos indica se as vesículas são unilamelares ou multilamelares ou mesmo a predominância de uma estrutura sobre outra. No modelo de ajuste, essa informação está intimamente relacionada ao número médio de camadas correlatas da vesícula, $N$. Se $N \approx 1$, então existe predominância de vesículas unilamelares. Se $N>1$, então existem vesículas unilamelares e multilamelares, com predominância dessa segunda estrutura.

O Gráfico mostrado na Figura abaixo (Figura 46) mostra os valores obtidos para o número médio de camadas correlatas.

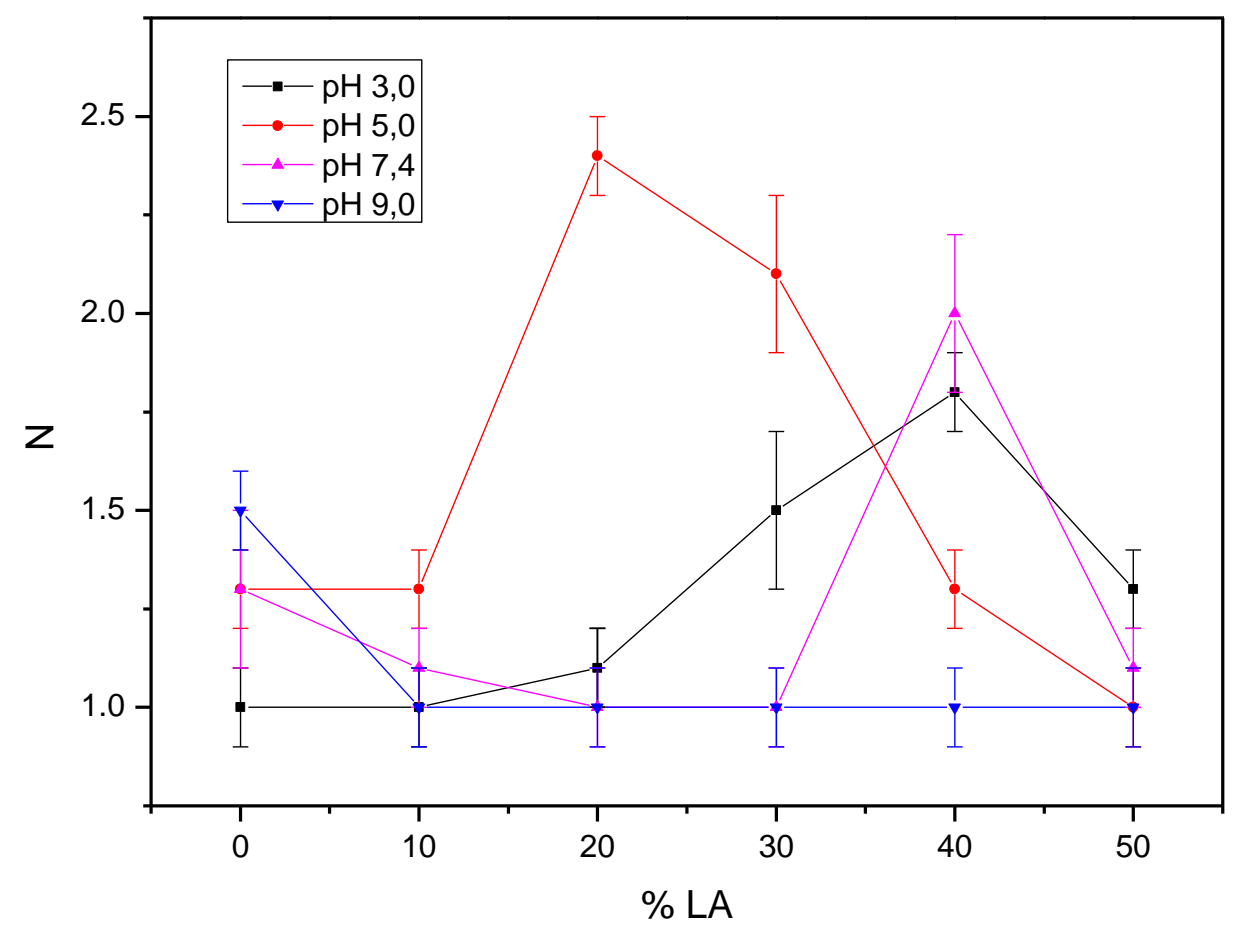

Figura 46- Comportamento do número médio de bicamadas correlatas, N, em função \%de LA das LUV; barras de erros com desvio padrão estão representadas verticalmente.

No gráfico mostrado na Figura 46 observamos que o número médio $N$ de bicamadas correlatas varia de maneira não previsível conforme se altera a quantidade de ácido láurico nas vesículas. O pH 9,0 é a única condição na qual as vesículas se mantem predominantemente unilamelares em todas as composições, exceto pela amostra contendo 
apenas DPPC. Neste pH o LA está desprotonado e com carga negativa; a sua presença na membrana, mesmo nas menores concentrações, parece ter favorecido a formação de LUV devido a forças eletrostáticas repulsivas que podem ter contribuído para a formação de apenas uma bicamada. Em pH 7,4, comportamento semelhante ao obtido para as amostras em pH 9,0 é observado, exceto pela amostra contendo $40 \%$ de LA. Seguindo este mesmo raciocínio, em pH 5,0 grande parte do LA já se encontra protonado e com carga líquida zero. Por isso, uma concentração maior de LA é necessária para favorecer a formação das LUV. O pH 3,0 foi a única condição em que a amostra contendo DPPC, sem LA, apresentou predominantemente vesículas unilamelares. A presença do LA, por outro lado, pareceu induzir a formação de MLV. Vale lembrar que o pH 3,0, como já dito anteriormente, afeta o pKa do grupo fosfato do DPPC, o que pode explicar os resultados encontrados para as amostras nesta condição.

\subsection{CRIOMICROSCOPIA ELETRÔNICA DE TRANSMISSÃO}

Com o objetivo de confirmar se as vesículas de DPPC/LA eram majoritariamente unilamelares e visualizar como a presença de LA afeta a estrutura da bicamada realizamos uma série de experimentos tentando visualizar e quantificar esses parâmetros.

Para caracterizar a morfologia das vesículas e verificar o efeito do $\mathrm{pH}$ e da concentração de LA nas LUV, seis amostras foram estudadas: DPPC, DPPC:LA 70:30 e DPPC:LA 50:50, cada uma delas nos pHs 7,4 e 5,0. Os ensaios de Criomicroscopia Eletrônica das amostras de LUV foram realizados no LNNano, localizado no CNPEM, sob a supervisão do Dr. Rodrigo Portugal.

As imagens obtidas para as amostras contendo apenas LUV de DPPC, nas duas condições de pH estão na Figura 47. 

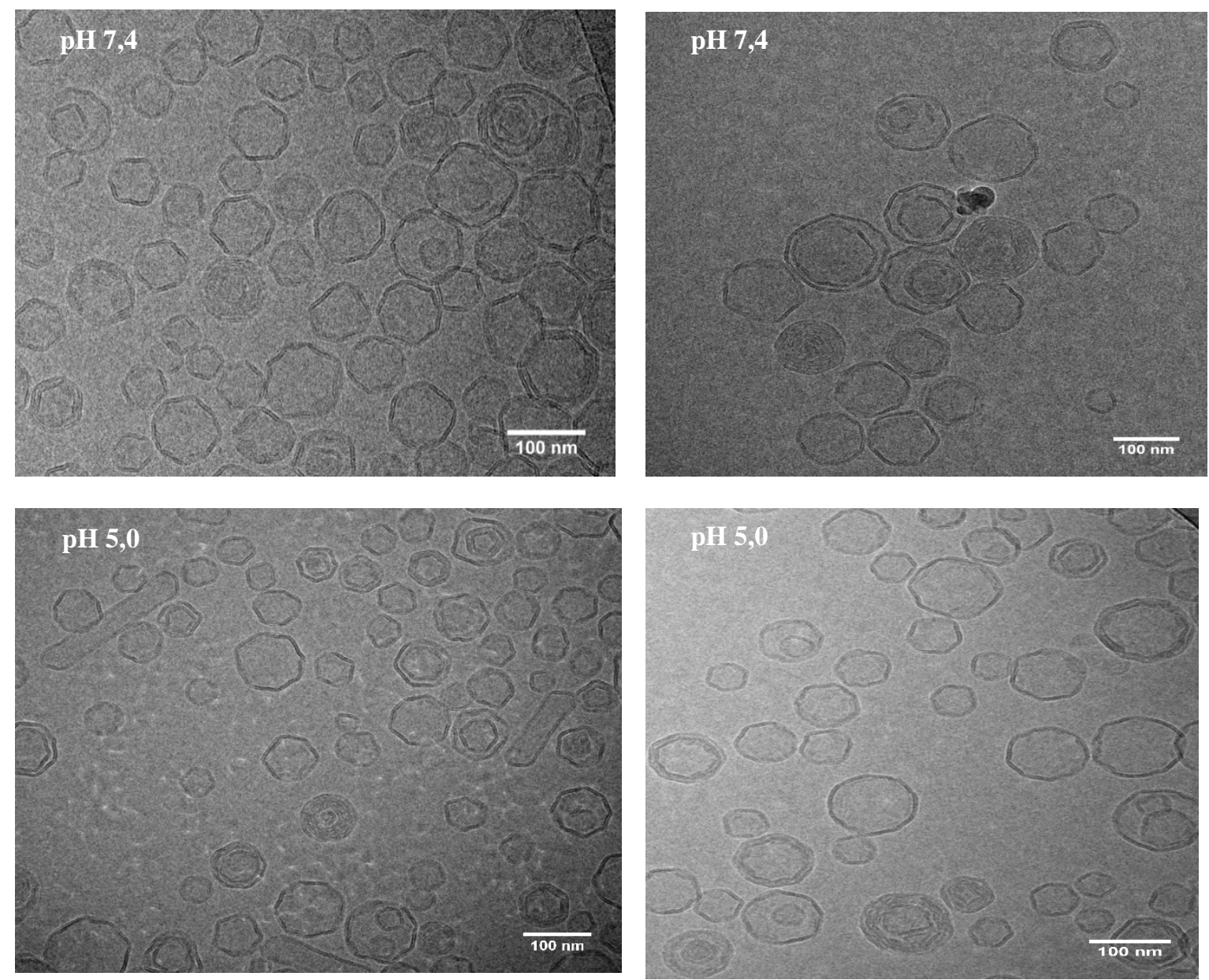

Figura 47- Imagens de Crio-EM de LUV de DPPC em pH 7,4 (acima) e pH 5,0 (abaixo).

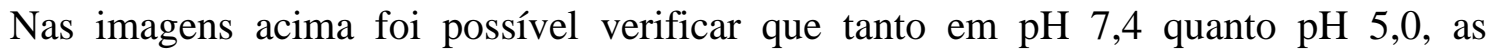
vesículas de DPPC apresentaram um aspecto "multifacetado", semelhante ao apresentado no trabalho de $\mathrm{Wu}$ et. Al, que realizou ensaios de criomicroscopia para uma amostra de DMPC (dimiristoilfosfatidilcolina).

Mesmo tendo sido extrusados com membrana com tamanho de poro de $100 \mathrm{~nm}$, foi observada uma quantidade significativa de vesículas oligolamelares. Nas imagens também foram visualizadas vesículas pequenas, menores que $100 \mathrm{~nm}$. A seguir, na Figura 48 estão as imagens obtidas para as amostras contendo $30 \%$ de LA, nos pHs 7,4 e 5,0. 

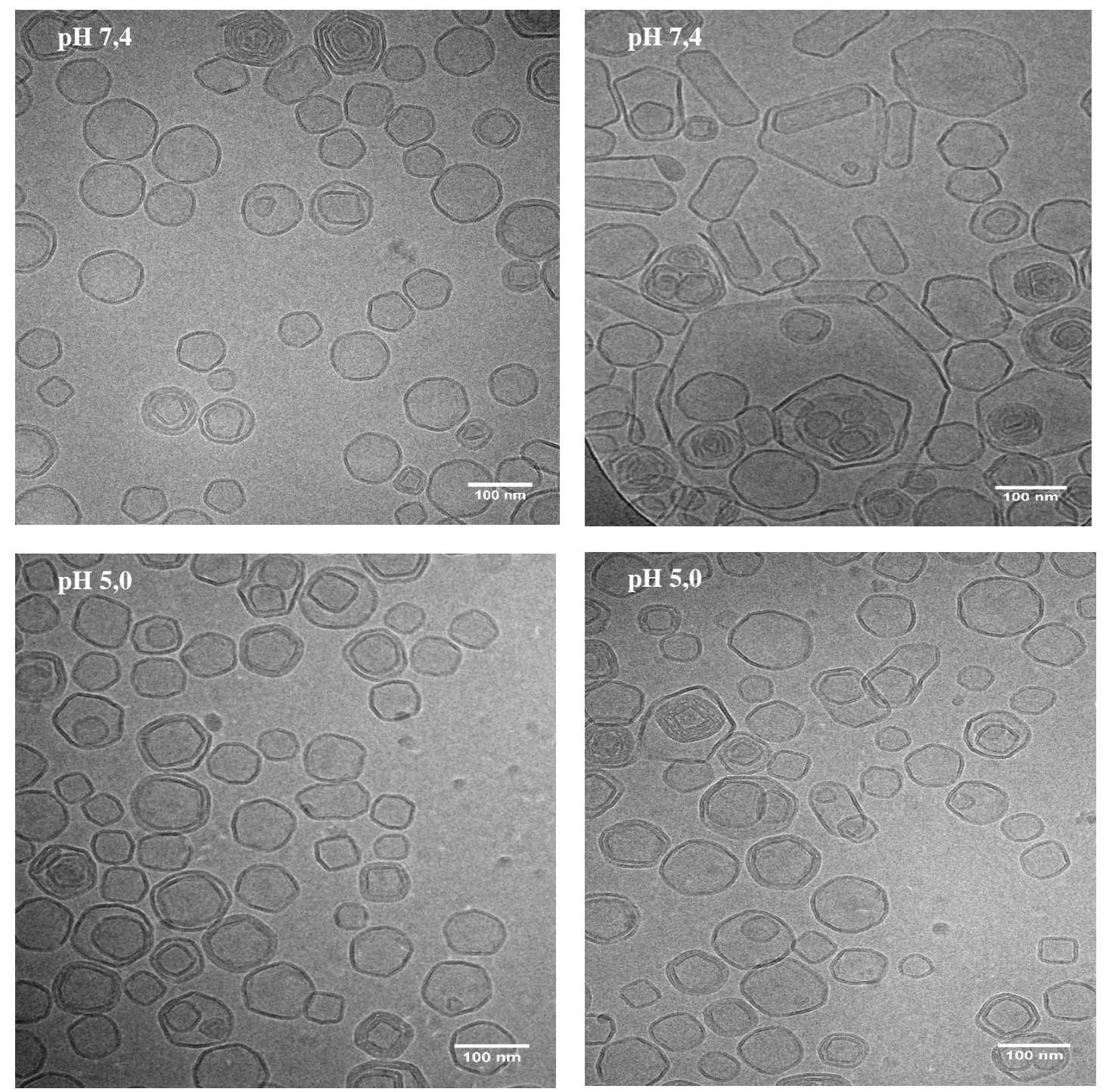

Figura 48- Imagens de Crio-EM de LUV de DPPC:LA 70:30 em pH 7,4 (acima) e pH 5,0 (abaixo).

Comparando as imagens das LUV com 30\% de LA com as amostras contendo apenas DPPC, observamos que a morfologia das vesículas sofreu alterações significativas. Kuntsche (2011) mostrou que a composição da bicamada e o método de preparo dos lipossomas estão diretamente relacionados ao seu aspecto morfológico (KUNTSCHE; HORST; BUNJES, 2011).

$\mathrm{Na}$ Figura 48 observamos, em ambas as condições de $\mathrm{pH}$, vesículas com duas bicamadas e menor quantidade de vesículas multilamelares, o que condiz com os dados apresentados de SAXS, em que o aumento da concentração de LA favorece a formação de vesículas unilamelares (Seção 4.5). Além disso, algumas vesículas com um formato semelhante a um quadrado e outras estruturas não esféricas foram observadas. Alguns desses formatos podem ser atribuídos a regiões da membrana com maior concentração de LA, formando domínios. 
Abaixo, na Figura 49, estão as imagens das amostras contendo 50\% de LA:
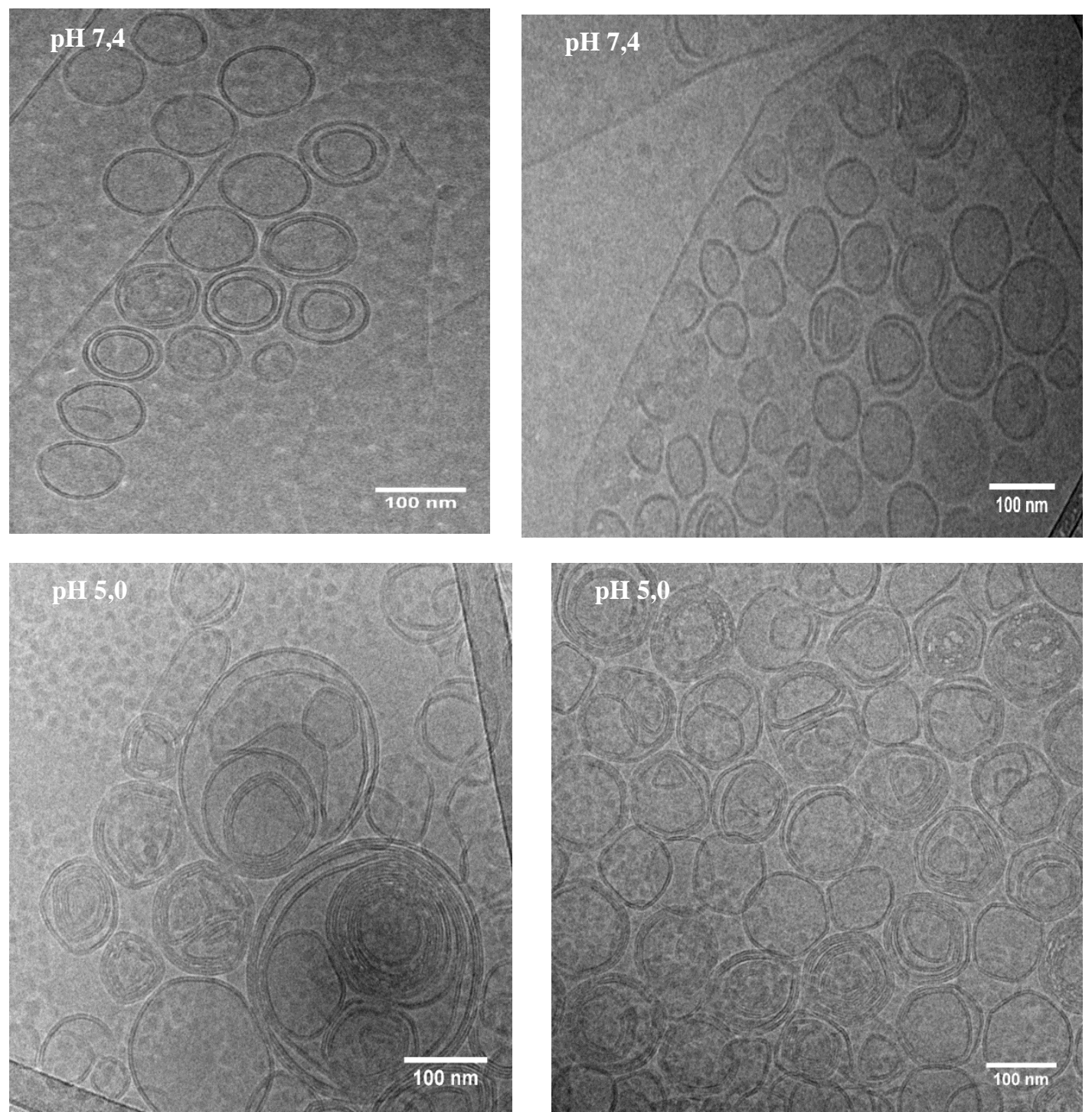

Figura 49- Imagens de Crio-EM de LUV de DPPC:LA 50:50 em pH 7,4 (acima) e pH 5,0 (abaixo).

As amostras contendo $50 \%$ de LA apresentaram vesículas com formato mais arredondado do que o observado nas imagens anteriores. Além disso, foram observados também alguns fragmentos de membrana, característicos de vesículas que se romperam devido à instabilidade.

Aparentemente quando a \% de LA é baixa, ele é segregado nas LUV pelo DPPC e ocorrem regiões heterogêneas na bicamada, formando domínios ricos em LA. Quando a \% de LA é alta, a bicamada fica mais homogênea e o DPPC não consegue se segregar devido a sua pequena quantidade na bicamada com relação ao LA. 


\subsection{ENCAPSULAMENTO DE SONDAS NO COMPARTIMENTO AQUOSO INTERNO DAS LUV}

O objetivo desses experimentos foi verificar se LUV contendo LA possuem um compartimento aquoso e se, existindo esse compartimento, a sua bicamada é permeável à passagem dos fluoróforos. Para isso determinamos a porcentagem de encapsulamento de $\mathrm{CF}$ nas LUV de DPPC com diferentes proporções de LA.

\subsubsection{Encapsulamento de CF em pH 7,4}

Vesículas de DPPC:LA (volume da amostra e concentração de lipídio) contendo CF 2 mM em tampão Tris/HCl 50 mM, pH 7,4, foram passadas em coluna de Sephadex e frações de $1 \mathrm{~mL}$ cada foram recolhidas em tubos de ensaio. As frações recolhidas no volume morto da coluna, Vo, continham vesículas com CF (ou PTS) e as frações finais (Vi) o fluoróforo não encapsulado. Em seguida, mediu-se a fluorescência do conteúdo de cada tubo. Quando necessário, diluiu-se a amostra para que a fluorescência obtida estivesse dentro da região linear da curva de calibração de Fluorescência vs [fluoróforo].

Este experimento foi repetido preparando-se LUV em diferentes proporções de DPPC/LA e calculou-se a porcentagem de encapsulamento para cada preparação (Tabela 5) utilizando a Equação 2. Os valores calculados da \% de encapsulamento de $\mathrm{CF}$ em pH 7,4 obtida experimentalmente estão na Tabela 3:

Tabela 3- Encapsulamento de CF em LUV 10 mM em Tampão Tris-HCl 50 mM pH 7,4.

\begin{tabular}{rc}
\hline Amostra & Encapsulamento CF (\%) \\
\hline DPPC & 0.43 \\
DPPC:LA 90:10 & 0.56 \\
DPPC:LA 80:20 & 0.89 \\
DPPC:LA 70:30 & 1.42 \\
DPPC:LA 60:40 & 1.41 \\
DPPC:LA 50:50 & 0.47 \\
\hline
\end{tabular}

Observa-se na Tabela 3 que LUV com até 50\% de DPPC/LA são capazes de reter CF e que, portanto, deve existir um compartimento aquoso que retém a CF. Curiosamente, em $\mathrm{pH}$ 
7,4 as amostras contendo ácido láurico incorporam uma porcentagem maior de CF do que as preparadas apenas com DPPC. A maior incorporação de CF se deu nas amostras contendo $30 \%$ e $40 \%$ de LA, o que pode indicar maior impermeabilidade das LUV devido à concentração de LA. A amostra com 50\% de LA também apresentou incorporação semelhante a 100\% DPPC o que mostra que mesmo nessa alta porcentagem de LA as LUV ainda mantêm a bicamada da com certa impermeabilidade, impedindo a livre passagem da $\mathrm{CF}$ para fora das vesículas.

\subsubsection{Encapsulamento de PTS em pH 5,0}

$\mathrm{O}$ mesmo procedimento utilizado para calcular a \% de encapsulamento de $\mathrm{CF}$ em $\mathrm{pH}$ 7,4 foi realizado em tampão acetato $50 \mathrm{mM}, \mathrm{pH}$ 5,0 incorporando-se PTS $1 \mathrm{mM}$ nas LUV. Calculou-se a \% de incorporação de PTS nas LUV usando-se a Equação 2.

Os resultados estão na Tabela 4.

Tabela 4- Encapsulamento de PTS em LUV 10 mM em tampão acetato 50 mM, pH 5,0.

\begin{tabular}{cc}
\hline Amostra & Encapsulamento PTS (\%) \\
\hline DPPC & 1.05 \\
DPPC:LA 90:10 & 0.97 \\
DPPC:LA 80:20 & 0.79 \\
DPPC:LA 70:30 & 0.57 \\
DPPC:LA 60:40 & 0.62 \\
DPPC:LA 50:50 & 0.61 \\
\hline
\end{tabular}

Em pH 5,0 observa-se que o maior encapsulamento se dá na amostra contendo apenas DPPC e conforme se aumenta a concentração de LA, menor é o encapsulamento de PTS, diferentemente do observado com a $\mathrm{CF}$ em $\mathrm{pH}$ 7,4. O valor da \% de encapsulamento usandose PTS como sonda nas LUV de DPPC foi maior do que o obtido usando CF. Isto pode significar que a bicamada das LUV de DPPC é mais permeável à CF do que ao PTS. Para verificar se as diferenças de encapsulamento encontradas são específicas para cada sonda os mesmos ensaios de incorporação foram repetidos utilizando a sonda CAT1 que foi monitorada por EPR. 


\subsubsection{Encapsulamento de CAT1 nas LUV}

A fim de estudar mais detalhadamente o encapsulamento pelas vesículas contendo LA nos $\mathrm{pHs}$ 7,4 e 5,0, os experimentos foram repetidos usando agora uma sonda carregada positivamente, o CAT1. Desta forma, também foi possível verificar se o encapsulamento observado anteriormente por fluorescência estava relacionado com interações eletrostáticas entre os fluoróforos e a bicamada das vesículas.

Neste método não houve necessidade de se eliminar a sonda externa à vesícula através de coluna de cromatografia. Para suprimir o sinal do CAT1 não incorporado nas LUV adicionou-se, após o registro do sinal de EPR da sonda, um volume de ácido ascórbico suficiente para eliminar a sonda não incorporada. Apenas a sonda que estava dentro das vesículas remanesceu devido à impossibilidade do ascorbato de atravessar a bicamada e reagir com o CAT1 dentro das LUV. Antes de realizar os experimentos com as LUV, foram feitos testes com controles sem as vesículas nas duas condições de $\mathrm{pH}$ estudadas para garantir que a concentração de ascorbato adicionada na cela era capaz de suprimir todo o sinal do CAT1 presente nas amostras.

Abaixo, na Tabela 5 estão os resultados obtidos para o experimento de encapsulamento com CAT1 em pH 7,4.

Tabela 5- Encapsulamento de CAT1 em LUV 10 mM em Tampão Tris-HCl 50 mM pH 7,4.

\begin{tabular}{cc}
\hline Amostra & Encapsulamento CAT1 (\%) \\
\hline DPPC & 1.13 \\
DPPC:LA 90:10 & 1.35 \\
DPPC:LA 80:20 & 1.44 \\
DPPC:LA 70:30 & 1.67 \\
DPPC:LA 60:40 & 1.39 \\
DPPC:LA 50:50 & 1.09 \\
\hline
\end{tabular}

Os resultados obtidos de \% de incorporação do CAT 1 (Tabela 5) se assemelham aos obtidos com $\mathrm{CF}$, mesmo que os valores absolutos sejam diferentes. Da mesma forma que para a CF, um máximo de incorporação da sonda foi alcançado em $30 \%$ de LA. Apesar de neste $\mathrm{pH}$ as vesículas com LA possuírem carga negativa, a carga da sonda utilizada não interferiu 
no encapsulamento já que esta não foi muito diferente da obtida com $\mathrm{CF}$, seguindo uma mesma tendência. Além disso, provavelmente a alta força iônica do tampão utilizado compete com o CAT1 pelos sítios negativos das vesículas e dificulta a ligação do CAT1 por forças eletrostáticas às membranas restando apenas as sondas incorporadas no compartimento aquoso interno das vesículas.

As LUV contendo CAT1 também foram preparadas em pH 5,0 e os dados encontramse na Tabela 6.

Tabela 6- Encapsulamento de CAT1 em LUV 10 mM em tampão acetato 50 mM pH 5,0

\begin{tabular}{cc}
\hline Amostra & Encapsulamento CAT1 (\%) \\
\hline DPPC & 1.14 \\
DPPC:LA 90:10 & 0.99 \\
DPPC:LA 80:20 & 0.85 \\
DPPC:LA 70:30 & 0.82 \\
DPPC:LA 60:40 & 0.78 \\
DPPC:LA 50:50 & 1.67 \\
\hline
\end{tabular}

Comparando-se o encapsulamento de CAT1 em pH 5,0 com os resultados obtidos com PTS, observa-se que, usando o CAT1, a maior \% de encapsulamento ocorreu na amostra com $50 \%$ de LA enquanto que com PTS o máximo de encapsulamento foi obtido para amostra sem LA.

Para uma melhor visualização, nas Figuras 50 e 51 estão dois gráficos, que comparam os resultados obtidos por fluorescência com aqueles obtidos por EPR. 
Encapsulamento CF e CAT1 em pH 7.4

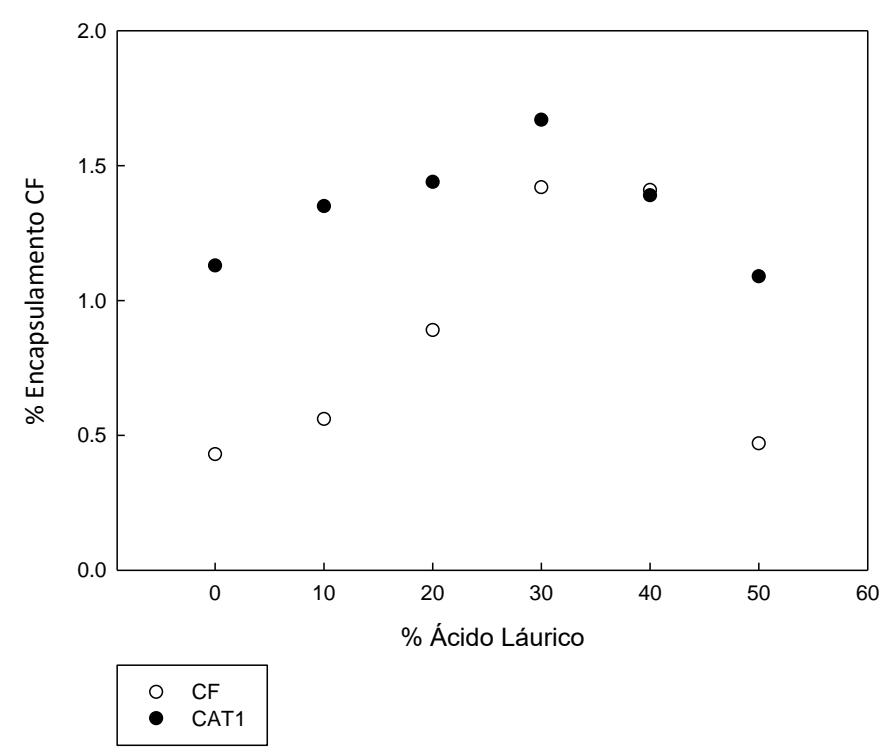

Figura 50- Comparação da porcentagem de encapsulamento de CF com o obtido usando CAT1 em LUV de DPPC:LA, ambos em tampão Tris-HCl 50 mM, pH 7,4.

Encapsulamento PTS e CAT1 em pH 5.0

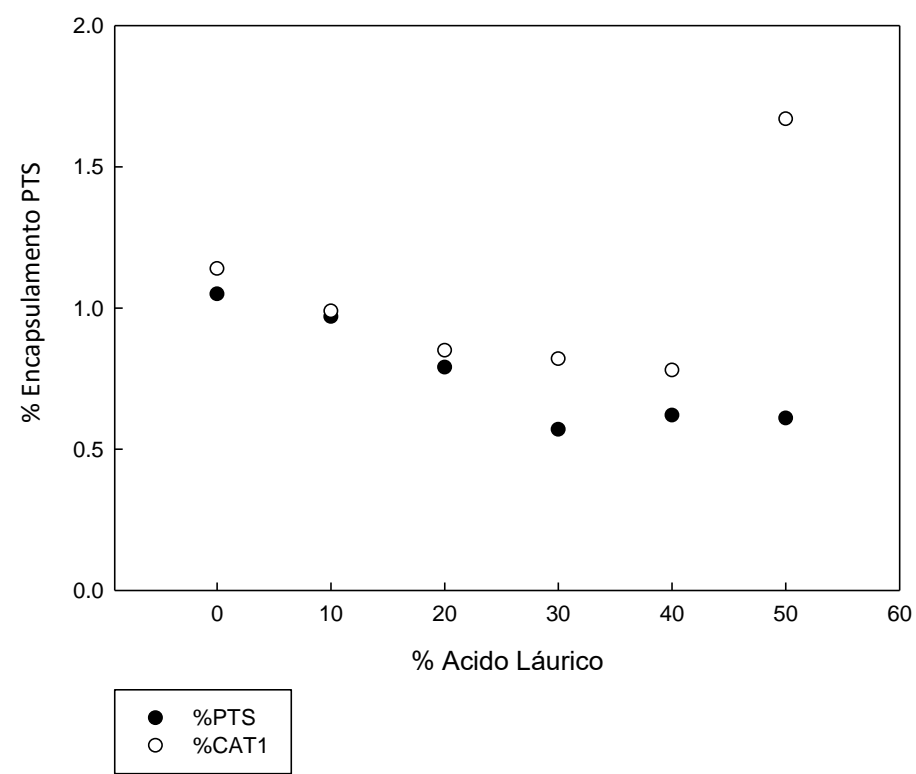

Figura 51- Comparação da porcentagem de encapsulamento de PTS com o obtido usando CAT1 em LUV de DPPC:LA, ambos em tampão acetato $50 \mathrm{mM}, \mathrm{pH}$ 5,0.

Na Figura 50 podemos observar que uma mesma tendência no encapsulamento ocorre tanto para o experimento de fluorescência com CF quanto para o com CAT1 por EPR em pH 7,4, apesar dos valores absolutos serem diferentes . Já em pH 5,0, como mostrado na Figura 51, os resultados obtidos com CAT 1 e PTS são muito semelhantes, à exceção da amostra 
com $50 \%$ de LA, que apresentou valores de \% de incorporação bastante diferentes entre as duas técnicas

\subsection{LIBERAÇÃO DO ÁCIDO LÁURICO MEDIDA POR DIÁLISE}

Para as LUV serem efetivas contra o microrganismo $P$. acnes, o LA deve permanecer incorporado nas vesículas. Desta forma, no desenvolvimento de lipossomas com a finalidade de drug delivery deve ser caracterizada a retenção e liberação do ativo in vitro. Conhecendo melhor estas propriedades, a formulação pode ser otimizada de forma a alcançar as melhores condições.

Neste ensaio estudamos a liberação de LA em função do tempo, a $25^{\circ} \mathrm{C}$ (temperatura próxima a ambiente), de forma a mimetizar as condições de prateleira e garantir que o ativo permanecerá incorporado nas vesículas até o seu uso.

Preparou-se amostras de LUV a vários pHs e cada amostra foi colocada numdispositivo de diálise (ver Métodos) e alíquotas da preparação foram retiradas a cada $1 \mathrm{~h}$. Na Figura 52 estão os resultados de \% de LA medido no compartimento aquoso externo para três amostras de DPPC:LA (90:10; 70:30 e 50:50) nos pHs 5,0 e 7,4, tampão acetato e tris-HCl, respectivamente, ambos na concentração de $10 \mathrm{mM}$. 
(a) DPPC:LA 90:10

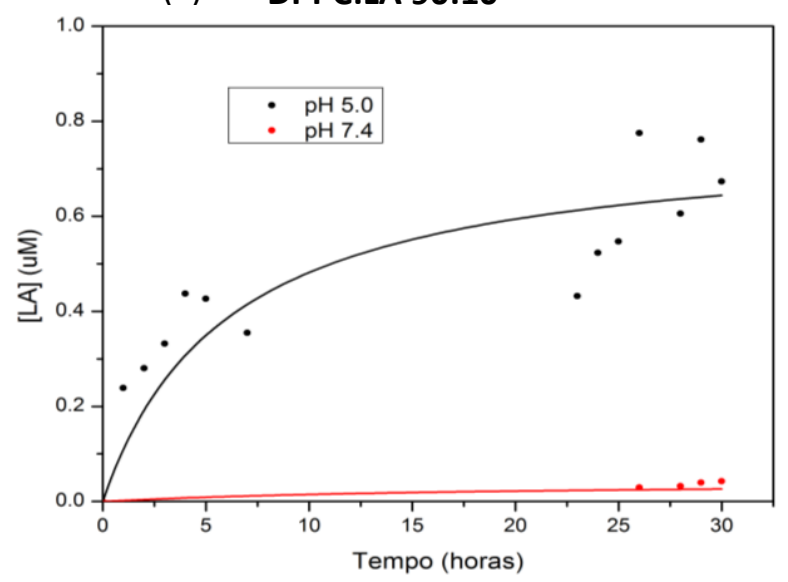

(b) DPPC:LA 70:30

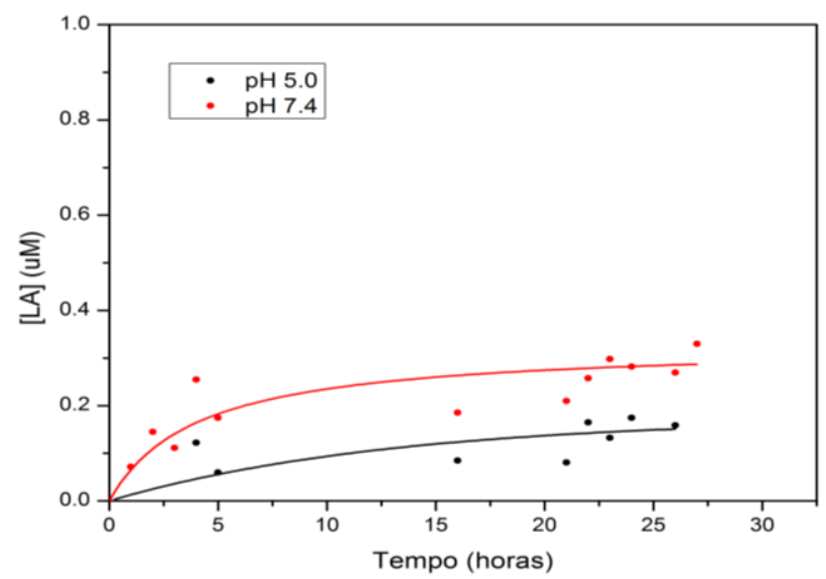

(c) DPPC:LA 50:50

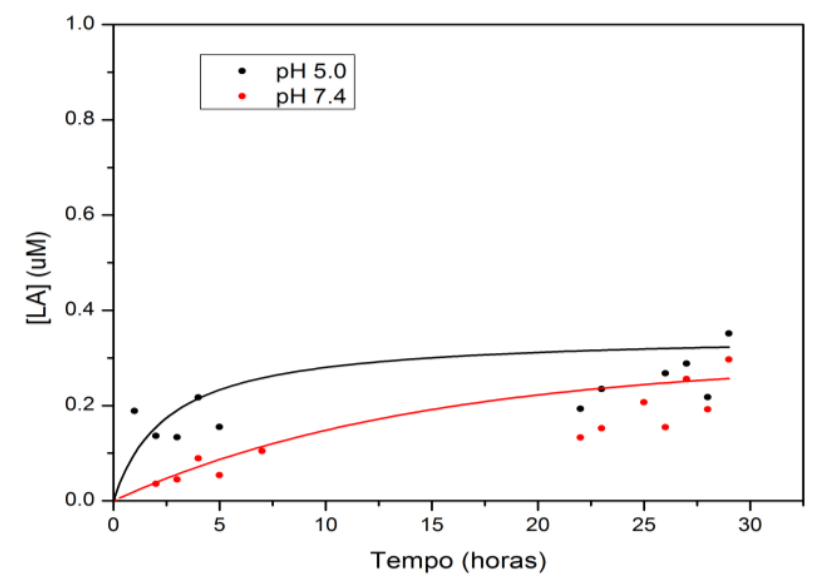

Figura 52- Concentração de LA liberado com o tempo das LUV de (a) DPPC:LA 90:10; (b) DPPC:LA 70:30 e (c) DPPC:LA 50:50 nos tampões acetato, 0.01 M pH 5,0 e tampão Tris-HCl 0.01 M 7,4. A concentração de LUV é 0.5 mM.

Era esperado que os lipossomas não passassem pelo poro da membrana de diálise, e apenas o LA fosse liberado, devido ao seu tamanho; sendo assim, esse ensaio não foi feito para uma amostra sem LA, uma vez que apenas o LA é quantificado.

Analisando os dados da Figura 52 podemos perceber que a amostra que mais libera ácido láurico em todas as condições de pH é aquela com apenas $10 \%$ de LA; porém, a liberação foi ainda mais favorecida em pH 5,0. Para a amostra com 30\% de LA, a liberação foi maior em $\mathrm{pH}$ 7,4 e com 50\% de LA os resultados obtidos foram semelhantes para ambas as condições. Observamos que quanto maior a porcentagem de LA, menor é a sua liberação. Em pHs maiores há maior concentração de laurato, carregado negativamente, que pode estar adsorvido na membrana de diálise, criando uma barreira com carga negativa, que impede a passagem de LA pela membrana nestas condições. Além do pH, quanto maior a concentração 
de LA nas LUV, maior é a possibilidade de que ele esteja criando esta barreira. Ainda estamos buscando entender melhor a relação entre as concentrações de LA e sua liberação.

\subsection{DIFUSÃO DO ÁCIDO LÁURICO POR CÉLULA DE FRANZ}

Estudamos também a permeação dos lipossomas contendo ácido láurico na pele, utilizando a Célula de Difusão de Franz. Os ensaios foram realizados nos pHs 7,4 e 5,0, com formulações contendo diferentes concentrações de LA.

Até o momento sabe-se que, independentemente do mecanismo de interação pele/LUV, as propriedades físico-químicas das vesículas como sua composição e carga afetam diretamente esta interação.

$\mathrm{Na}$ Figura 53 estão os resultados obtidos para as formulações em tampão tris- $\mathrm{HCl} 10$ mM, pH 7,4 e na Figura 54 em tampão acetato 10 mM, pH 5,0.

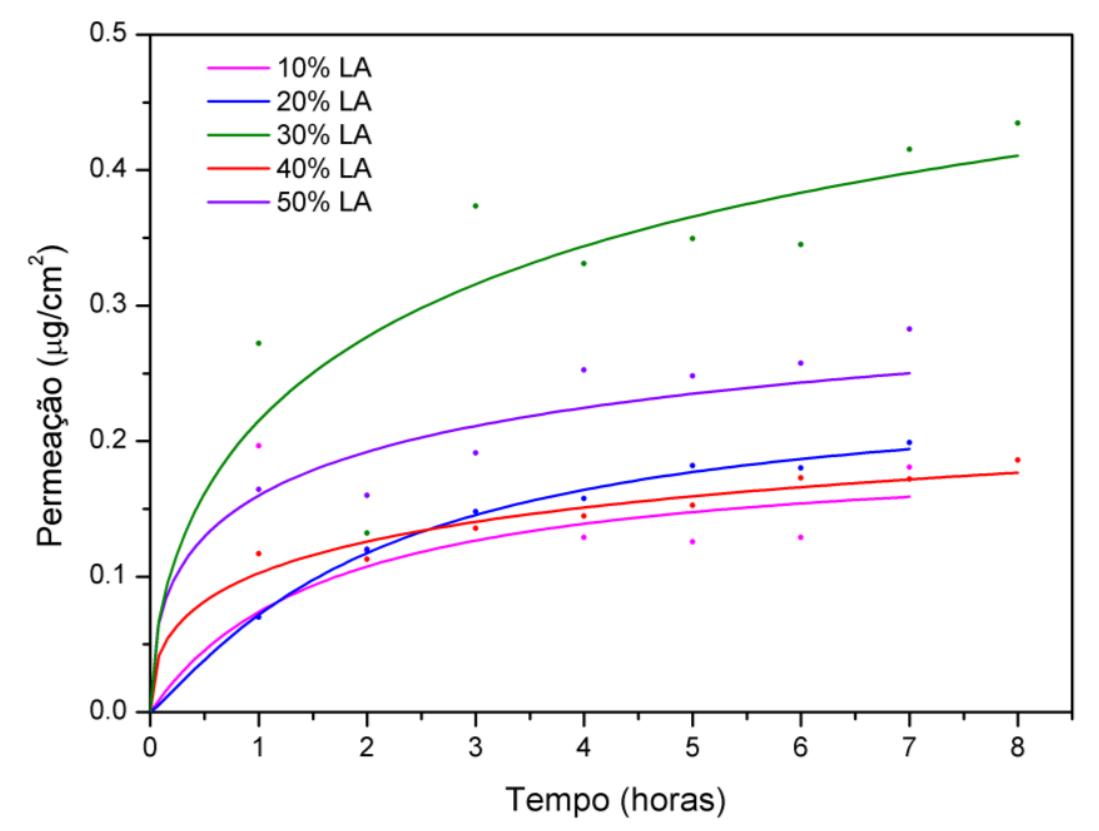

Figura 53- Porcentagem de permeação de LA com o tempo de LUV de DPPC:LA em tampão Tris-HCl $10 \mathrm{mM}$, $\mathrm{pH} 7,4$. [LUV] $=0.5 \mathrm{mM}$. 


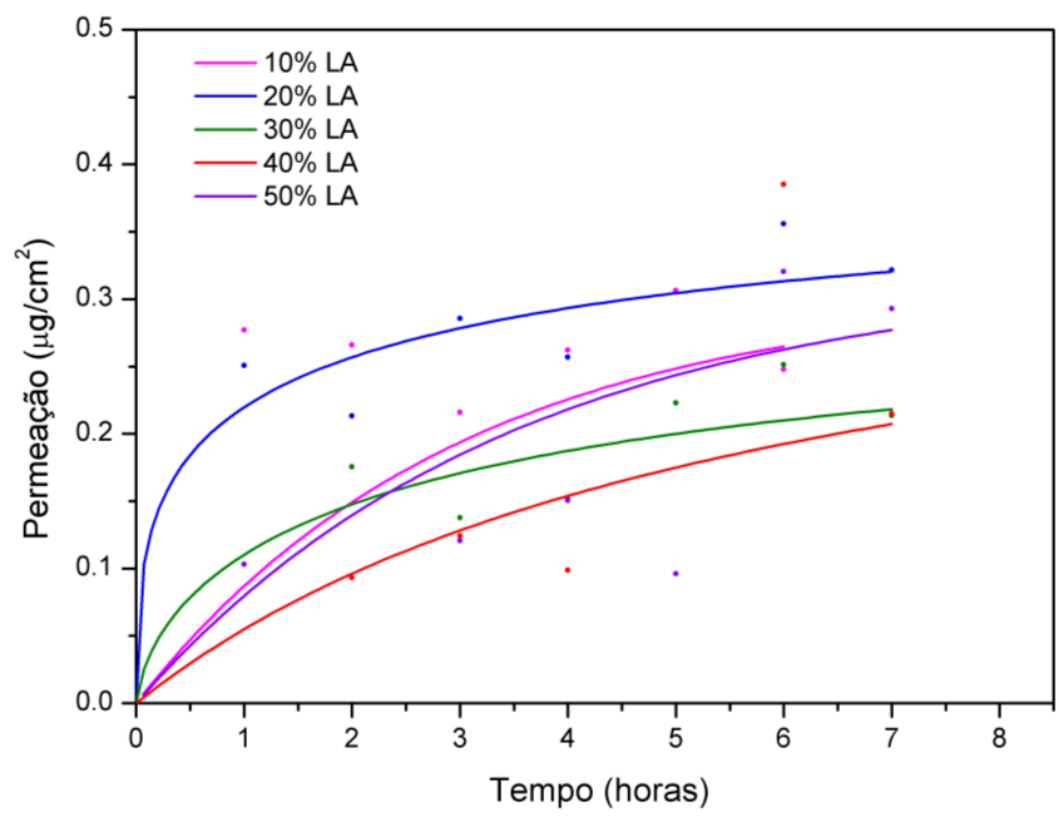

Figura 54- Porcentagem de permeação de LA com o tempo de LUV de DPPC:LA em tampão acetato $10 \mathrm{mM}$, pH 5,0. [LUV] $=0.5 \mathrm{mM}$.

Observa-se nas figuras que o LA atravessa a pele com o aumento do tempo e chega a um valor máximo e aproximadamente constante após $2 \mathrm{~h}$.

Em pH 7,4 observamos que a amostra que melhor permeou a pele foi aquela contendo $30 \%$ de LA e a que menos permeou foi a com 10\% de LA, a menor concentração estudada. Já em pH 5,0 a maior taxa de permeação foi obtida com a amostra contendo apenas $20 \%$ de LA.

Desta forma, observamos que as amostras com concentrações mais altas de LA não foram as que mostraram maior permeação. É sabido que a pele age como uma barreira negativamente carregada e que vesículas carregadas negativamente geralmente difundem melhor do que aquelas carregadas positivamente. As vesículas carregadas positivamente se acumulam na camada mais superficial da pele e não atingem o sítio de interesse (EGBARIA; WEINER, 1990). Porém, se a concentração de LA nas LUV for muito alta (principalmente no pH 7,4), a difusão das LUV através da pele pode ser dificultada. Isso explicaria por que as amostras com 50\% de LA não tiveram maior permeação do que as LUV contendo menor porcentagem de LA.

Os resultados de um trabalho realizado com lipossomas contendo Tretinoína (SINICO et al., 2005) mostraram que o tamanho das vesículas, e a sua lamelaridade, não afeta significativamente a liberação de ativos sobre pele de porco, porém os melhores resultados obtidos em termos de permeação foram alcançados com formulação de lipossomas pequenos, negativamente carregados e com uma Tm menor do que a temperatura da superfície da pele. 
Bouwstra et al. (2003) mostrou que o estado termodinâmico das vesículas tem um papel importante na liberação de ativos sobre a pele. A incorporação de ativos em LUV no estado gel parece resultar em uma permeação mais lenta do que no estado fluido.

Além da carga das vesículas contendo LA, é provável que as alterações que o ácido láurico causa na Tm do DPPC e, consequentemente, a alteração da fluidez das LUV também esteja relacionada à taxa de permeação. Nos ensaios de DSC, verificamos que quanto mais baixo o pH, mais o LA influenciou na Tm, aumentando o seu valor. Possivelmente em pH 5,0 esse efeito foi ainda mais acentuado. 


\section{CONCLUSÕES}

Os lipossomas contendo ácido láurico se mantiveram estáveis a $25^{\circ} \mathrm{C}$ durante o período de 30 dias nos pHs 9,0 e 7,4, que apresentaram diâmetro hidrodinâmico estável e menor polidispersidade. Nos pHs 5,0 e 3,0 a estabilidade física dos lipossomas não se manteve durante esse mesmo período de tempo. Mesmo que o $\mathrm{pH}$ 5,0 seja o valor de $\mathrm{pH}$ que melhor representa a condição de $\mathrm{pH}$ da pele, $\mathrm{pHs}$ mais altos favoreceram a estabilidade da formulação.

O LA se manteve dentro das vesículas por quase 30 horas, quando se acompanhou a sua liberação a $25^{\circ} \mathrm{C}$ nos pHs 7,4 e 5,0. As amostras com concentração maior de LA foram as que apresentaram menores \% de liberação com o tempo.

Os resultados de DSC mostraram que a presença do LA nas bicamadas aumenta a sua temperatura de transição de fase e diminui a cooperatividade, principalmente em valores de $\mathrm{pH}$ mais baixos, quando grande parte do LA está protonado e com carga líquida zero. Por outro lado, os experimentos de SAXS mostraram que, abaixo da Tm, a $25^{\circ} \mathrm{C}$, o LA parece deixar a membrana menos flexível em todos os pHs, mesmo em pequenas concentrações de LA.

Os ensaios de encapsulamento de CF e PTS por fluorescência e de CAT1 por EPR mostraram que o LA favorece o encapsulamento de compostos hidrofílicos no compartimento interno aquoso das vesículas, principalmente em $\mathrm{pH}$ 7,4. Em pH 5,0 foram encontrados resultados semelhantes de incorporação de PTS e CAT1, com exceção das LUV com 50\% LA. Provavelmente o baixo encapsulamento encontrado para ambas as condições de $\mathrm{pH}$ se deve a uma diferença de permeabilidade da membrana das vesículas e também à lamelaridade. Observou-se nas imagens de crio-TEM que muitas amostras apresentaram vesículas multilamelares e multivesiculares, o que diminui o encapsulamento de sondas hidrofílicas no compartimento interno aquoso das vesículas.

A morfologia das vesículas apresentou diferenças consideráveis dependendo do $\mathrm{pH}$ e da concentração de LA. Como observamos por SAXS, a espessura da bicamada não variou muito entre as diferentes amostras, mas o número de camadas correlatas variou bastante. Isso foi confirmado pelas imagens de crio-TEM que mostrou vesículas com mais de uma bicamada e morfologias muito diferentes daquelas esperadas e encontradas na literatura. É possível que até uma determinada concentração de LA ele forme domínios na membrana (regiões pontuais 
com maior concentração de LA) e que a partir desta concentração a mistura se torne mais homogênea com o LA distribuído uniformemente.

As vesículas contendo LA em $\mathrm{pH}$ 7,4 e pH 5,0 foram capazes de permear a pele de orelha de porco no período de aproximadamente $8 \mathrm{~h}$. As amostras com maior concentração de LA liberaram menos LA do que as LUV com $10 \%$ LA nas duas condições de pH. Considerando-se que a pele é carregada negativamente, tal como as vesículas contendo LA (em pH 7,4), é possível que exista um máximo de concentração de LA que favoreça a sua difusão na pele.

A caracterização físico-química das vesículas contendo LA mostrou que estes agregados possuem características interessantes para sua aplicação não somente em formulações cosméticas, como proposto inicialmente, mas também são relevantes para o estudo de misturas de lipídios e ácidos graxos e aspectos relacionados à morfologia, estabilidade e diferenças de permeabilidade das vesículas. 


\section{REFERÊNCIAS BIBLIOGRÁFICAS}

\section{AGÊNCIA NACIONAL DE VIGILÂNCIA SANITÁRIA. Guia de Estabilidade de} Produtos Cosméticos. [s.l: s.n.]. v. 1

AROURI, A.; MOURITSEN, O. G. Membrane-perturbing effect of fatty acids and lysolipids. Progress in Lipid Research, v. 52, n. 1, p. 130-140, 2013.

ASCHI, M. et al. Physicochemical Properties of Fluorescent Probes : Experimental Carboxyfluorescein. Journal of Organic Chemistry, v. 73, n. 3, p. 3411-3417, 2008.

BARROSO, R. Dispersões lipídicas de dimiristoil fosfatidilglicerol: um estudo termoestrutural. Tese de Doutorado, Instituto de Física da Universidade de São Paulo, 2011.

BIBI, S. et al. Microscopy imaging of liposomes: From coverslips to environmental SEM. International Journal of Pharmaceutics, v. 417, n. 1-2, p. 138-150, 2011.

BLUME, G.; CEVC, G. Liposomes for the sustained drug release in vivo. Biochimica et Biophysica Acta, v. 1029, n. 1, p. 91-97, 1990.

BOJAR, R. A.; HOLLAND, K. T. Acne and propionibacterium acnes. Clinics in Dermatology, v. 22, n. 5, p. 375-379, 2004.

CROWE, J. H.; MCKERSIE, B. D.; CROWE, L. M. Effects of free fatty acids and transition temperature on the stability of dry liposomes. Biochimica et Biophysica Acta, v. 979, n. 1, p. 7-10, 1989.

DAVIDSEN, J.; MOURITSEN, O. G.; JØRGENSEN, K. Synergistic permeability enhancing effect of lysophospholipids and fatty acids on lipid membranes. Biochimica et Biophysica Acta (BBA) - Biomembranes, v. 1564, n. 1, p. 256-262, 2002.

DESBOIS, A. P.; SMITH, V. J. Antibacterial free fatty acids: activities, mechanisms of action and biotechnological potential. Applied Microbiology and Biotechnology, v. 85, n. 6, p. 1629-1642, 2010.

EADY, E. A et al. The effects of acne treatment with a combination of benzoyl peroxide and erythromycin on skin carriage of erythromycin-resistant propionibacteria. British Journal of Dermatology, v. 134, n. 1, p. 107-113, 1996.

EGBARIA, K.; WEINER, N. Liposomes as a topical drug delivery system. Advanced Drug Delivery Reviews, v. 5, n. 3, p. 287-300, 1990.

ELMAN, M.; LEBZELTER, J. Light therapy in the treatment of acne vulgaris. Dermatologic surgery : official publication for American Society for Dermatologic Surgery [et al.], v. 30, n. 2 Pt 1, p. 139-146, 2004.

FISCHER, C. L. et al. Antibacterial Activity of Sphingoid Bases and Fatty Acids against Gram-Positive and Gram-Negative Bacteria. Antimicrobial Agents and Chemotherapy, v. 56, n. 3, p. 1157-1161, 2012. 
GERBELLI, B. B. Propriedades estruturais e elásticas de fases lamelares. Dissertação de Mestrado, Instituto de Física, Universidade de São Paulo, 2012.

GOLDBLUM, O. M. Acne vulgaris. SKINmed, v. 2, n. 5, p. 309-311, 2003.

GOLLNICK, H.; SCHRAMM, M. Topical drug treatment in acne. Dermatology, v. 196, n. 1, p. 119-125, 1998.

GONÇALVES, M. DE C. Desenvolvimento, caracterização físico-química e avaliação biológica de quitossomas para liberação cutânea de melatonina. Dissertação de Mestrado, Faculdade de Fármácia, Universidade Federal do Rio Grande do Sul, 2008.

JAPPE, U. Pathological mechanisms of acne with special emphasis on Propionibacterium acnes and related therapy. Acta Dermato-Venereologica, v. 83, n. 4, p. 241-248, 2003.

JESPERSEN, H. et al. Lipids, curvature stress, and the action of lipid prodrugs: Free fatty acids and lysolipid enhancement of drug transport across liposomal membranes. Biochimie, v. 94, n. 1, p. 2-10, 2012.

JIN, A. J. et al. Light scattering characterization of extruded lipid vesicles. European Biophysics Journal, v. 28, n. 3, p. 187-199, 1999.

KATSAMBAS, A.; PAPAKONSTANTINOU, A. Acne: Systemic treatment. Clinics in Dermatology, v. 22, n. 5, p. 412-418, 2004.

KLANG, V. et al. Electron microscopy of nanoemulsions: An essential tool for characterisation and stability assessment. Micron, v. 43, n. 2-3, p. 85-103, 2012.

KUNTSCHE, J.; HORST, J. C.; BUNJES, H. Cryogenic transmission electron microscopy (cryo-TEM) for studying the morphology of colloidal drug delivery systems. International Journal of Pharmaceutics, v. 417, n. 1-2, p. 120-137, 2011.

LASIC, D. D. Novel applications of liposomes. Trends in Biotechnology, v. 16, n. 7, p. 307$321,1998$.

LEWIS, R. N. A H. et al. Differential Scanning Calorimetry in the Study of Lipid Phase Transitions in Model and Biological Membranes. Methods in Molecular Biology. Vol:400, Methods in Membrane Lipids. , v. 400, 2008.

LEYDEN, J. J. et al. Propionibacterium acnes resistance to antibiotics in acne patients. Journal of the American Academy of Dermatology, v. 8, n. 1, p. 41-5, 1983.

MANZINI, M. C. Efeito da Carga dos Lipídios na Interação do BP100 em Modelos de Membrana. Dissertação de Mestrado, Instituto de Química, Universidade de São Paulo, 2011.

MARIA, A.; ALVES, B.; COIMBRA, U. DE. Efeitos de Ocupação Molecular nas Propriedades Termotrópicas de diferentes Bicamadas Lipídicas. Universidade de Coimbra, Portugal, 2013. 
MCDOWELL, A. et al. Propionibacterium acnes Types I and II Represent Phylogenetically Distinct Groups Propionibacterium acnes Types I and II Represent Phylogenetically Distinct Groups. Journal of Clinical Microbiology,v. 43, n. 1, p. 326-334, 2005.

MCGINLEY, K. J. et al. Regional variations in density of cutaneous propionibacteria: Correlation of Propionibacterium acnes populations with sebaceous secretion. Journal of Clinical Microbiology, v. 12, n. 5, p. 672-675, 1980.

MELO, F. A. D. E. Interações moleculares no mecanismo de ação de clorocatecol 1 , 2dioxigenase e da tirosina quinase FGFR2. Tese de Doutorado, Instituto de Física de São Carlos, Universidade de São Paulo, 2010.

MEZEI, M.; GULASEKHARAM, V. Liposomes - a selective drug delivery system for the topical route of administration. I. Lotion dosage form. Life Sciences, v. 26, n. 14, p. 1473$1477,1980$.

MORIGAKI, K.; WALDE, P. Fatty acid vesicles. Current Opinion in Colloid \& Interface Science, v. 12, n. 2, p. 75-80, 2007.

MORROW, B. H.; KOENIG, P. H.; SHEN, J. K. Atomistic simulations of pH-dependent selfassembly of micelle and bilayer from fatty acids. The Journal of Chemical Physics, v. 137, n. 19, p. 194902, 2012.

NAKATSUJI, T. et al. Antimicrobial Property of Lauric Acid Against Propionibacterium Acnes: Its Therapeutic Potential for Inflammatory Acne Vulgaris. Journal of Investigative Dermatology, v. 129, n. 10, p. 2480-2488, 2009.

NEWTON, J. N. et al. The effectiveness of acne treatment: an assessment by patients of the outcome of therapy. The British journal of dermatology, v. 137, n. 4, p. 563-7, 1997.

PUC-RIO. Introdução à Fluorescencia. Disponível em: http://www.maxwell.vrac.pucrio.br/15676/15676_3.PDF Acesso em: 11 nov 2015. PUC-Rio, 2006.

PURDY, S.; DE BERKER, D. Acne vulgaris. BMJClinical Evidence (Online), v. 2011, n. 9813, p. 361-372, 2011.

SANTOS, J. et al. Desenvolvimento de um método de análise de vitamina $\mathrm{C}$ em alimentos por cromatografia líquida de alta eficiência e exclusão iônica. Ciência e Tecnologia de

Alimentos, v. 27, n. 4, p. 837-846, 2007.

SCHREIER, S. Estudos Estruturais e Dinâmicos de Membranas pelo Método do

Marcador de Spin. Tese de Livre- Docência, Instituto de Química, Universidade de São Paulo, 1979.

SINICO, C. et al. Liposomes as carriers for dermal delivery of tretinoin: In vitro evaluation of drug permeation and vesicle-skin interaction. Journal of Controlled Release, v. 103, n. 1, p. 123-136, 2005.

STRAUSS, J. S.; KLIGMAN, A. M. Pathologic Dynamics of Acne Vulgaris. Archives of Dermatology, v. 82, p. 779-790, 1960. 
TORCHILIN, V. P. Recent advances with liposomes as pharmaceutical carriers. Nature Reviews. Drug discovery, v. 4, n. 2, p. 145-160, 2005.

TOYODA, M.; MOROHASHI, M. An overview of topical antibiotics for acne treatment. Dermatology, v. 196, n. 1, p. 130-134, 1998.

VAN EKEREN, P. J. Handbook of Thermal Analysis and Calorimetry. [s.l: s.n.]. v. 407

WEBSTER, G. F. Inflammation in acne vulgaris Pennsylvania. Journal of American Academy of Dermatology, v 33, p. 247-253, 1995.

WEISS, J. S. Current options for the topical treatment of acne vulgaris. Pediatric Dermatology, v. 14, n. 6, p. 480-488, 1997.

YANG, D. et al. The antimicrobial activity of liposomal lauric acids against Propionibacterium acnes. Biomaterials, v. 30, n. 30, p. 6035-6040, 2009.

ZAMARION, V. Funcionalização de Nanopartículas Plasmônicas para o Desenvolvimento de Sensores SERS, Anexo:Espalhamento De Luz Dinâmico - Dinamic Light Scattering (DLS). Tese de Doutorado, Instituto de Química, Universidade de São Paulo, 2012. 